\title{
The Forgotten Soundtrack of Maoriland: Imagining the Nation Through Alfred Hill's Songs for Rewi's Last Stand
}

\section{Melissa Cross}

\author{
A thesis submitted to Massey University and \\ Victoria University of Wellington in fulfilment of \\ the requirements for the degree \\ Master of Music in Musicology
}

Te Kōkī

New Zealand School of Music

2015 


\begin{abstract}
Alfred Hill's songs based on collected Māori musical materials and narrative themes are artefacts of cultural colonisation that represent individual identities and imagined communities. They are tangible evidence of the site of identity formation known as Maoriland within which Pākehā construct imaginings of 'Māoriness' to create their own sense of indigeneity and nationhood. Although early twentieth-century Maoriland has been discussed widely in the arts and literature, scholars have not addressed the music of Maoriland, perhaps because it is heard today as the cultural form that most clearly expresses racialised sentimentality and colonial hegemony. However, Maoriland music can tell us much about New Zealand society if it is recognised as inhabiting an 'in-between' place where Pākehā fascination for the racial other was often inseparable from an admiration for Māori promoted by a knowledgeable group of Māori and Pākehā cultural go-betweens.

This thesis presents a critical cultural analysis of the ethnic, racial, gendered, and national identities represented in Hill's 'Māori' songs, viewed through the lens of his use of these in his score for Rudall Hayward's film Rewi's Last Stand (1940). This analysis shows that these popular songs contributed, and continue to contribute, to the nexus of Māori, war, and music in Pākehā narrations of the nation. By applying a bicultural approach to the study of Hill's Maoriland songs, this research also shows these 'in-between' songs represent individual, tribal, and national Māori identities too. While this work adds music to the discourse of Maoriland, and Maoriland to the discourse of New Zealand music and national identity, Hill's 'Māori' music, early twentieth-century New Zealand music, and New Zealand film music all remain severely underresearched areas of New Zealand music studies.
\end{abstract}


Abstract iii

Table of Contents $\quad$ iv

Acknowledgements $\quad \mathrm{V}$

List of Illustrations vi vi

Abbreviations vii

A Note on Language viii

Chapter One Introduction: Progress Through Paradise 1

Chapter Two 'In-Between' Music: Alfred Hill's 'Māori' Songs 15

Hill, Hira, and Te Hiwi 15

Musical Colonialisms 25

The Language of Maoriland Music $\quad 27$

Chapter Three 'Let's build a nation': Rewi's Last Stand 31

James Cowan, the New Zealand Western, and Destiny 32

Cultural Sensitivity, 'Authenticity', and the Nation 34

Songs of Myth 41

Chapter Four Singing Māori Home: 'Home, Little Maori, Home' 47

Waiata Aroha, Makereti Papakura, and the Maoriland Maiden 47

Sentiment, War, and Rikihana Carkeek 53

Rewi's Last Stand: Ariana, Ramai Te Miha, and Intimacy 63

Chapter Five Civilising the Frontier: 'Song of the Locust' 73

Henry Stowell, Haka, and Preserving Māori 74

Rewi's Last Stand: 'War-like sounds' of Musical Conversion 82

Kiri Te Kanawa, 'Tarakihi', and Māori Land 96

$\begin{array}{lr}\text { Conclusion } & 103\end{array}$

Appendices

$\begin{array}{lll}\text { I } & 109\end{array}$

II Cue $12 \quad$ 'Canoe Pursuit'. Rewi's Last Stand 111

III Cue 21a 'Haka of Defiance'. Rewi's Last Stand 117

IV Cue $29 \quad$ 'Maori Defiance'. Rewi's Last Stand 133

$\begin{array}{ll}\text { Reference List } & 145\end{array}$ 


\section{Acknowledgements}

I thank the enthusiastic archivists and librarians who assisted me with this project, especially Meredith Lawn of ML, Mishelle Muagututi'a, Diane Pivac, and Virginia Callanan of NZFA, Ariana Tikao and Keith McEwing of ATL, Amanda Mills of the Hocken Library, Catherine Jehly of TAM, Nigel Champion of AMPM, and Sarah Johnston of NZSA. I also thank Alistair Gilkison for his help in identifying the editions of 'Home, Little Maori, Home', and Max Cryer for his permission to use the photograph of Kiri Te Kanawa and Māori choir. I am grateful to my inspirational teachers Erin Taylor who rekindled my love for the piano, Allan Thomas who showed me where to find new musics, and Keith Chapin who taught me the value of precise, elegant argument. Thanks also to Donald Maurice and Robert Hoskins for their early encouragement, Cecilia Vincent and Lynne Wenden for their listening ears, and my supervisors Brian Diettrich and Stephan Prock for guiding me in my interrogation of music that challenges the values and beliefs that underpin my own sense of identity. My deepest appreciation goes to my parents for the piano lessons, and especially to my husband Philip and sons James and Christo for their steadfast love and support. 
Figures

Fig. 1 Home, Little Maori, Home. 1911. Auckland: A. Eady and Co. 51

Fig. 2 Te Miha, Ramai.c.1940. PH299. TAM 66

Fig. 3 Te Miha, Ramai.c.1940. PH300. TAM 66

Fig. 4 Home, Little Maori, Home. 1939. Auckland: Charles Beggs \& Co. 66 (detail)

Fig. 5 Kiri Te Kanawa and Māori Choir. 1999. Courtesy of Max Cryer 98

Musical Examples

Ex. 1 'Song of the Locust'. bb.1-13 84

Ex. 2 'Song of the Locust'. bb.17-20 84

Ex. 3 'Song of the Locust'. bb.27-30 85

Ex. 4 Rewi's Last Stand. Cue 12: 'Canoe Pursuit'. bb.1-8 87

Ex. 5 Rewi's Last Stand. Cue 12: 'Canoe Pursuit'. 'Maniapoto' motif. 88 bb.30-41

Ex. 6 Rewi's Last Stand. Cue 19: 'Bullock Teams Drawing Guns'. bb.1-12 91

Ex. 7 Rewi's Last Stand. Cue 21: 'Battle Music'. 'Crown' motif. bb.1-3 92

Ex. 8 Rewi's Last Stand. Cue 21a: 'Haka of Defiance'. 'Maniapoto' motif. 92 bb.105-108

Ex. 9 Rewi's Last Stand. Cue 21a: 'Haka of Defiance'. 'Crown' motif. 93 bb.41-44

Ex. 10 Rewi's Last Stand. Cue 29: 'Maori Defiance'. Fugue subject. bb.1-10 94 


\section{Abbreviations}

Institutions

AMPM Archive of Māori and Pacific Music, Auckland University

ANZ Archives New Zealand Te Rua Mahara O Te Kāwanatanga

ATL Alexander Turnbull Library, National Library of New Zealand Te Puna Mātauranga O Aotearoa

ML Mitchell Library, State Library of New South Wales

NZFA New Zealand Film Archive Ngā Kaitiaki O Ngā Taonga Whitiāhua

NZSA New Zealand Sound Archives Ngā Taonga Kōrero

TAM Te Awamutu Museum

Collections

AHMM Alfred Hill Music Manuscripts, Hill Family collection

AHPP Alfred Hill Personal Papers, Hill Family collection

EHEP E.H. Everton Papers

HC Hayward Collection

HMSP Henry Matthew Stowell Papers

JCP James Cowan Papers

JMTP John Mansfield Thomson Photographs

WSCR Wellington Savage Club Records 
The language used in this thesis is New Zealand English, which incorporates Māori words and concepts. Macrons for extended Māori vowels are omitted from historical terms and quotations in which they are not used. As a historically non-Māori word, I do not use a macron for 'Maoriland'. Māori words are glossed in the text in the first instance. For more comprehensive definitions please visit Māori Dictionary: Te Aka Māori-English, English-Māori Dictionary at http://maoridictionary.co.nz. Song titles appear within the text in inverted commas even when these songs were later published individually. In 1943 Rudall Hayward divorced his first wife, Hilda, and married Ramai Te Miha, the star of Rewi's Last Stand. In this thesis I refer to Ramai accordingly as she was before and after this marriage. 


\section{Chapter One}

Introduction: Progress Through Paradise

On 18 May 1911 Sydney's Evening News reported that composer Alfred Hill had 'rescued real Maori music from oblivion', a claim that Hill upheld throughout his life (Plimmer 1953,16). While this assertion has proved with the passing of time and the advent of the Māori cultural renaissance to be a somewhat patronising overstatement it does sum up Hill's lifelong philosophy regarding the music of a people he greatly admired. Hill believed that in collecting and popularising Māori music he was preserving a threatened Māori culture for Māori, and in the first half of the twentieth century many Māori (indigenous New Zealanders) and Pākehā (European settlers and their descendants) supported him, sometimes describing his songs as Māori music (for example Papakura, 10 October 1909, AHPP, box 2; 'A New Maori Song', Radio Record, 5 June 1931, 2).

Hill's 'Māori' songs are tangible evidence of an ongoing process of 'cultural colonisation' by which, '...people in settler societies present [multiple identities] within the kaleidoscope of daily life, adjusting gender roles, ethnicity, sexuality and "nationality" day by day, and even hour by hour, as they are constituted and reconstituted in different social situations' (Gibbons 2002, 15). In particular, they represent the early twentieth-century imaginary site of identity formation known as Maoriland (Blythe 1994, 16-18), within which Pākehā appropriated indigenous culture to imagine a collective 'Māoriness' that they then used to construct their own sense of indigeneity and nationhood (Belich 2001, 329). This thesis argues that Hill's 'Māori' songs demonstrate the ambivalence of individual and collective Pākehā and Māori identities of ethnicity, race, and gender, and that these in turn contribute to the nexus of Māori, war, and music in Pākehā narrations of the nation.

In this thesis I present critical cultural analyses of Hill's 'Māori' songs 'Home, Little Maori, Home' and 'Song of the Locust', considered through the lens of his use of these in his score for Rudall Hayward's 1940 film Rewi's Last Stand (hereafter Rewi). During the first half of the twentieth century Hill's 'Māori' 
songs were widely known (for example 'Quartets and Songs', Auckland Star, 12 May 1939, 14), and as such provide ideal examples with which to consider the relationship between Hill's music and national identity in this period. As a film with a cross-culturally inspired score and dual narrative of the historical New Zealand Wars battle of Ōrākau and a fictionalised interracial romance, Rewi provides an opportunity to apply an interdisciplinary approach to fictional, artistic, musical, visual and historiographical representations presently absent from research of the nation (Berger 2011, 10).

Music scholars have questioned the continuing relevance of the nation as a primary cultural unit (see Taruskin 2001, 703), however ethnomusicologist Henry Johnson $(2010,1)$ has recently argued that within a nation-state's geographical boundaries 'individuals might have a cultural identity that is related to notions of being or becoming, or may live transcultural or transnational lives where ideas of national identity are obfuscated across real and imagined borders'. Further, historian Michael King (2008, author's note) argues that nations must understand their past before they can consider their future, and that to do this Pākehā must become bicultural in a way that many Māori are by necessity. King's approach to history, culture, and identity, his challenge to Pākehā, and the continuing Pākehā practice of appropriating Māori culture motivate me to understand the positive reception by both Pākehā and Māori of Hill's 'Māori' songs during his own lifetime.

\section{Literature Review}

This thesis relies on the critical analysis and in places re-evaluation of a considerable amount of archival material. I approached this material mindful of Tony Ballantyne's $(2012,187)$ point that archives are themselves artefacts of colonisation that can help scholars explore the language and cross-cultural communication of Māori and Pākehā 'knowledgeable groups'. 


\section{Primary Sources}

Rewi apparently survives today only as The Last Stand, a shortened version released in Britain in 1949. This was commercially re-released in 1990 as Rewi's Last Stand (Hayward), and has been recently restored by the NZFA as Rewi's Last Stand/ The Last Stand (Hayward 1949). ${ }^{1}$ Hayward's scenario for Rewi relies heavily on James Cowan's official history, The New Zealand Wars (1983 [1922, 1923]) and his story of Te Awamutu, The Old Frontier (2001[1922]); this scenario in turn forms the basis for a contemporary novel (Hayward and Reed, 1944[1939]). Production and publicity materials and correspondence for Rewi are held in the HC, NZFA. In addition the TAM holds film company records, publicity material, and local newspaper clippings. No complete script for the original 1940 production or detailed information on the 1949 re-edit has come to light.

The majority of Hill's archived materials are held in the Hill Family collection at the ML. Within these his music manuscript collection (AHMM) includes orchestral parts for Rewi, partial scripts for the film, his 'Māori' songs, and an apparently unused score for a film that became Hei Tiki (Markey 1935). These materials also include a collection of photographs and Hill's personal papers (AHPP) consisting of, in part, libretti and lyrics by Hill and others, his Leipzig diary, correspondence, newspaper clippings, and autobiographical notes. ${ }^{2}$ Copies of some photographs from this collection are held in JMTP, ATL. A number of Hill's important music manuscripts have yet to be located (Stiles Music Publications 2008), and other primary sources are unavailable to researchers at present (Lam 2006a, 25).

Published editions of Hill's 'Māori' songs 'Home, Little Maori, Home' (1911), 'Waiata Poi' (c.1904), Songs of the Maori (1926), which includes 'Song of the Locust', and Alfred Hill's Maori Album (1951) are widely available. Hill's less well-known published 'Māori' songs are held in private collections (for example see Gilkison 2008), and the ATL. Early commercial recordings of Hill's 'Māori' songs are held in the ATL and the Hocken Library, University of Otago. Due to

1 The NZFA holds fragments of Hayward's first Rewi's Last Stand (1925).

2 Hill's diary was published in 2008. 
the largely ephemeral nature of domestic music making and a lack of statistics for sheet music and record sales and specific film attendances for the period under discussion, this thesis relies partly on contemporary newspaper articles concerning Hill's 'Māori' songs and Rewi. ${ }^{3}$

Hill discusses his approach to Māori music in many audio, newspaper, and magazine interviews (audio interviews: Hill [1950s], Hill 1952a, Hill 1952b, ATL; Hill 1958, NZSA). The 'reminiscences' included in his later interviews are often in fact direct quotations by Hill and others selectively drawn from much earlier newspaper clippings held in his papers. Hayward describes Hill's approach to collecting Māori music in a 1960 radio broadcast and provides his autobiography and information on Hill's film music in a c.1961 interview with then National Film Library Director Walter Harris. The self-editing processes and expressions of mutual admiration in Hayward and Hill's interviews are themselves part of the broader discourse of nationalism.

\section{$\underline{\text { Secondary Sources }}$}

New Zealand film music and popular Pākehā songs of the early twentieth century have received little academic attention (respectively, Ferreira 2012, 3; Harding 1992, 1). Regarding Hill's music specifically, scholars have largely focused on his art music, approaching this from a text-based perspective (for example Jensen 1952; McCredie 1968; Covell 1993; Crowley 2001; Stiles 2007). ${ }^{4}$ However, between 1958 and 1998 John Mansfield Thomson wrote extensively on the subject of Hill's art music within its Pākehā social context. In 1980 he published A Distant Music, an account of Hill's life that focuses on his art music career in Sydney while footnoting his relationship with Māori. Sarah Shieff (1994) expands the theme and approach of Thomson's book by placing 'Waiata Poi' and Hill's cantata Hinemoa (1896) at the peripheries of Empire and a New Zealand art music tradition. Where briefly mentioned elsewhere, Hill's 'Māori'

\footnotetext{
${ }^{3}$ Pre-1945 New Zealand newspaper articles cited are available through the National Library's resource Papers Past (http://paperspast.natlib.govt.nz/cgi-bin/paperspast), except those from the Te Awamutu Courier (ARC3630, TAM). Australian newspaper articles cited but not held in Hill's papers as indicated are available through National Library of Australia's resource Trove (http://trove.nla.gov.au).

${ }^{4}$ Stiles' thematic catalogue is to be published at a later date.
} 
songs have been approached from a cross-cultural perspective (Thomas 1981, 27; 2011, 10-13; McLean 1996, 313-314; Bourke 2010, 33-35). Recently Hill's Māori-inspired art music has also been considered in this context (Lam 2006a, 2006b; Maurice 2004, 2006). Apparently no field research among Māori communities regarding Hill's contact with Māori has been undertaken. This thesis aims to kindle interest in neglected areas of New Zealand music and demonstrate the necessity to situate the study of Hill's 'Māori' music within cross-cultural social contexts.

The body of literature on Rewi is divided with some overlap into the areas of production record (Evans 1994; Martin and Edwards 1997; Pivac 2011), biographies of Hayward (Horton 1973; Edwards and Murray 2007), biographies of Ramai Hayward (Wharerau 1989; Amoamo 1993; Ramai Hayward 1986, 1996; Shepard 2005), and critical cultural analyses based on The Last Stand (Sklar 1971; O’Connor 1979; Campbell 1986; Mita 1992; Blythe 1994; Perkins 1996; Babington 2011; Fox 2011; Cooper 2013). This thesis further aims to contribute to the body of critical work on Rewi, promote dialogue between New Zealand musicologists, media scholars, and cultural historians, and more widely, to add to the understanding of music's part in the colonising of the screen.

Methodology

Imagined Communities

Benedict Anderson's work on the nation, and in particular his recognition of the nation as an 'imagined community', provides the first core concept for the theoretical framework of this thesis. Anderson $(2006,5)$ identifies three paradoxes which present a challenge for students of nationalism: 'The objective modernity of nations to the historian's eye vs. their subjective antiquity in the eyes of nationalists'; 'The formal universality of nationality as a socio-cultural concept...vs. the irremediable particularity of its concrete manifestations...'; and "The "political" power of nationalisms vs. their philosophical poverty and even incoherence'. Nonetheless he offers this definition: 
[The nation is] an imagined political community... imagined because the members of even the smallest nation will never know most of their fellowmembers, meet them, or even hear of them, yet in the minds of each lives the image of their communion'. (ibid., 6. emphasis in the original)

From Anderson's comments we can appreciate that the nation is an elusive, constantly reforming, hegemonic construction particular to the individual yet understood by the collective.

The imaginary character of the nation has been extended to other communal identities, for example sociologist David Pearson $(2001,16)$ notes:

Nationality, 'race', and ethnicity are not natural categories or predetermined identities, they are political constructs with shifting memberships and meanings. They are ways of naming oneself and others, of representing identities and interests within different orders of collectivity...

To these communities we may add gender. Gender theorist Judith Butler (1999, xxiv-xxv) allows that there may be a psycho-social element to her theatrical and linguistic model of gender, an identity category which she asserts is 'manufactured through a sustained set of acts, posited through the gendered stylization of the body' (ibid., xv). The four imagined communities of nation, race, ethnicity, and gender form fluid webs of identity that depend on individual perceptions of otherness and performances of self to produce cultural artefacts that embody real political power and produce tangible outcomes. In recognition of the part the individual plays in constructing imagined communities, this thesis privileges personal stories.

\section{Myths of Origin}

The second theoretical core concept that informs this thesis is that of New Zealand settlers' myths of origin. Pearson $(2001,73)$ describes British colonial settler myths of origin as those of the 'home past' and 'home present'. During the nineteenth century the new home of New Zealand was 'sold' to prospective British emigrants under the three motifs of Progress, Paradise, and 'Britishness' (Belich 1996, 287). While 'Britishness' or the home past was implicit under the colonial regime, settlers transformed Progress and Paradise into two dominant late nineteenth-century myths of 'New Zealandness': 
respectively, pioneer frontierism and the romantic picturesque. Both myths were complicated by the presence of Māori, and each dealt with Māori in a different way according to the hegemonic racialised trope of Culture/Nature. Stuart Hall $(2013,233)$ explains:

Among whites, 'Culture' was opposed to 'Nature'. Among blacks, it was assumed, 'Culture' coincided with 'Nature'. Whereas whites developed 'Culture' to subdue and overcome 'Nature', for blacks 'Culture' and 'Nature' were interchangeable.

In the local context 'natural' Māori were confined within the Paradise of Maoriland, but through the acculturating process of Progress were offered civility, modernity, and entry to New Zealand.

\section{Progress and the Nation}

Anderson $(2006,36)$ argues that the notion of the nation arose in the early eighteenth century with the decline of three ancient cultural axioms: privileged script-based knowledge allows access to ontological truth; society is naturally organised under a divine monarch; and the temporality of cosmology and history, the origins of the world and humans, is essentially identical. The rise of print capitalism linked fraternity, power, and time, allowing for the possibility of 'rapidly growing numbers of people to think about themselves, and to relate themselves to others, in profoundly new ways' (ibid.). This popular nationalism led to the official nationalisms of the nineteenth century, which were an imperial means of combining naturalisation with retention of dynastic power (ibid., 88).

From the beginning of official nationalism in New Zealand Pākehā and Māori imagined their political relationship differently. During 1840 Crown representatives and approximately 500 rangatira (chiefs) signed the Treaty of Waitangi, a document written in English and then, according to historian James Belich (1996, 194), intentionally mistranslated into Māori. The English version 'gave the Maori the "rights and privileges", and implicitly the duties, of British subjects; guaranteed their possession of all their land and property... [and] ceded "absolutely and without reservation all the rights and powers of Sovereignty"' (ibid.). The 'key difference' between this and the Māori version 
was that the latter split the powers with which it dealt into two: 'kawanatanga' (governorship), which went to the British; and 'rangatiratanga' (chieftainship), which was retained by Maori; further the British received 'te kawanatanga katoa' (full government) while Māori received 'te tino rangatiratanga' (unqualified exercise of their chieftainship) (ibid.). Neither the two versions nor the split powers within the Māori version were 'easily compatible' (ibid.). ${ }^{5}$

Anderson (2006, 6-7) argues that the nation is such a powerful construction that people will die to uphold its imagined reality; these deaths in turn forming new notions of nation. In New Zealand since 1840 there have been discrete and powerful episodes of war and war commemoration that continually reconstitute the nation. Initially the country suffered internal conflict today known as the New Zealand Wars. During the 1840s the Crown fought with certain iwi (tribes) to establish local geographical and political boundaries, but during the 1860s it fought, Belich (1996, 229-231) argues, not to specifically put down the Kīngitanga (Māori King movement) or acquire land but to uphold colonial ideology that insisted on New Zealand rule 'in fact as well as name'. One of the most decisive Crown victories during the 1860s was the Waikato battle at Ōrākau (ibid., 238), where on 31 March 1864 approximately 300 Māori from seven iwi staged a siege in Ōrākau Pā (fortification) under Ngāti Maniapoto leader Rewi Maniapoto (Cowan 1983, 1:373). During this siege, in response to Ensign William Mair's call for surrender, a person (by one account Rewi himself) called out 'Ka whawhai tonu matou, ake, ake, ake!' ('We shall fight on, for ever, and ever, and ever!') (Mair quoted in ibid., 1:391). After three days the Māori force fled the pā and were massacred; in all seventeen British soldiers and 160 Māori were killed (ibid., 1:401). This battle did not, however, result in British rule over the Waikato. Māori land was confiscated and the boundary redrawn between Pākehā territory and what became known as the King Country (Belich 1996, 238).

Hayward's Rewi is one of many historiographies of this conflict, dating back to Edward Fitzgerald's article in the Press a fortnight after the battle

\footnotetext{
${ }^{5}$ Since the 1970s the Treaty of Waitangi has been rehabilitated as the nation's founding document, and celebrated (less often challenged) annually on 6 February.
} 
(Cooper 2013, 154), in which Pākehā constructed the Māori of Ōrākau as 'civilised brothers' through Pākehā admiration of Māori courage in the face of insurmountable odds. This ideology of interracial martial fraternity appeared to play out in World War One where Māori served in the Māori Contingent at Gallipoli and the Pioneer Battalion in France. ${ }^{6}$ The Contingent was made largely of descendants of kūpapa iwi (indigenous Crown allies) from the New Zealand Wars, but the slippery nature of imaginary communities allowed Pākehā to perceive the Māori of Ōrākau and those of the Contingent as one and the same, thereby assuming that a national Mãori collective was compliant with the colonial regime. Through this apparently successful process of Progress a symbolically civilised national Māori community joined with Pākehā to become New Zealanders. The Pākehā self was upheld and the home present assured, while Māori and indeed all other ethnic minorities were marginalised.

The Paradise of Maoriland

The New Zealand settlers' myth of Progress relies on the Eurocentric premise that Māori are the racial other. Edward Said $(1995,2)$ describes the coloniser's desire to define self in relation to the colonised other as Orientalism. Orientalism expresses and represents materials 'culturally and even ideologically as a mode of discourse with supporting institutions, vocabulary, scholarship, imagery, doctrines, even colonial bureaucracies and colonial styles' (ibid.). Scholars have discussed Pākehā fascination with Māori in many of these areas: literature (Phillips 1983; Gibbons 2002; Stafford and Williams 2006); tourism (Diamond 2007, 17-18; Derby 2012b); fine art (Blackley 1997, 17); photography (King 2008, 7-24); ethnology (Kernot 1998); interior design (Petersen 2000); and widely within film as cited above. Martin Blythe (1994, 3-5, 17) has most thoroughly interrogated the characteristics and hegemonic potential of Pākehā Orientalist texts, describing three ways in which early Pākehā films on Māori narrative themes distanced the other: stereotyping, temporality, and language.

${ }^{6}$ The Gallipoli campaign commenced 25 April 1915 and is the origin of New Zealand's annual day of remembrance, Anzac Day (Australia and New Zealand Army Corps). 
While types are necessary for the production of meaning, stereotyping essentialises, naturalises, and fixes difference (Hall 2013, 247). Belich (2001, 206-210) identifies three main late nineteenth-century Pākehā stereotypes of Māori: the pathetic or ferocious unconvertible Black Māori; the Grey Māori, a race dying from the effects of European contact; and the White Māori, asserted by scholars such as Edward Tregear to be members of an 'Aryan master race'. Ostensibly this last stereotype defied racial difference and the need for conversion, however it was always tinged by other stereotypes. Belich (2001, 210) argues that initially the Grey and White Māori merged and so justified Pākehā appropriation of Māori culture. Later, during the 1920s, as the Māori population began to recover and New Zealand society began the cultural phase of a re-orientation toward Britain, which Belich calls 'recolonisation' (ibid., 29), the White Māori became the 'Brown Briton' (ibid., 209). While the 'culture' of the Grey-White Māori was salvaged, that of the Brown Briton was patronised in acts of recolonial benevolence.

These Black, White and Grey stereotypes were employed by Pākehā to contain Māori within a distant Māori home past. European representation of non-western people as the 'primordial man' of prehistory developed in classical antiquity, was elaborated on during the Enlightenment, and in the nineteenth century became formalised into the 'comparative method', which in making moral judgments divided indigenous people into Noble and Ignoble Savages (McNiven and Russell 2005, 14, 23-25). In New Zealand this temporal distancing was reinforced through romanticised retellings of Māori myths and traditions in the arts, literature and ethnography, which featured Noble Savages such as the nubile Grey-White 'maiden' and fierce yet honourable Black-White 'warrior'. These stereotypes were influenced by the American Indian stereotypes of contemporary American literature and from 1892 were lent colonial authority through the anthropological resources of the Polynesian Society (Phillips 1983, 528-530; Stafford and Williams 2006, 11).

Language holds great potential to distance the other: '...to name is to "own", and to own is to forget origins' (Blythe 1994, 3). The term 'Maori land' applied originally to land for which Māori held customary or legal title, but from 
1863 when Frederick Maning's Old New Zealand was published it came to describe a pre-Pākehā New Zealand (Orsman 1997, 478). From the 1880s as one word Maoriland was adopted as a popular synonym for a contemporary New Zealand; the Sydney Bulletin eventually abbreviating it to 'ML' (Phillips 1983, 527-528). The subversion of Maori land is apparent in the titles of numerous Pākehā texts such as those of early twentieth-century 'Maoriland' postcards, Charles Goldie's portrait of Nataria Mitchell and child Day Dreams: Christmas Time in Maoriland (1902), Maxime Heller's Maoriland Waltzes (1905), ${ }^{7}$ and the Labour journal Maoriland Worker (1910-1924). There can be no greater sign of the power of naming, however, than the coloniser's assumption of the name of the colonised and in the early twentieth century Pākehā including Hill styled themselves 'Maorilanders' ('Maori Music in Modern Compositions', Timaru Herald, 4 October 1913, 7; Orsman 1997, 479).

Māori land was originally the name for various geographical sites owned by Māori. As a conflation of 'prehistoric' and pre-Pākehā Māori homes past and a settler home present, however, Maoriland came to be an ideological site of Pākehā identity formation. To validate their presence in a land already occupied, Pākehā distanced and contained the racial other within 'authentic' romanticised pasts. They then appropriated this essential 'Māoriness' and employed the White Māori and Brown Briton stereotypes to construct their racial and martial brotherhood with Māori. This served to reinforce both Pākehā ethnicity and national identity, and an imagined racially harmonious national community. In Rewi Hayward offers Māori Progress as the way out of Paradise, but it is through the very presence of Maoriland and Hill's Maoriland songs in particular that his nationalist project aims to succeed.

The Forgotten Soundtrack of Maoriland

In reality Māori did not melt into the community of Pākehā New Zealander Britons. Nor did they fade into pre-history leaving Pākehā to write an epitaph to Māori culture. Indeed, Māori resistance against the Crown regarding the Treaty during the nineteenth century is testament to their presence as

\footnotetext{
${ }^{7}$ Heller was a pseudonym for English composer Charles Rawlings
} 
vibrant ethnic communities, and their service in World War One suggests that many Māori proudly considered themselves New Zealanders and members of the British Empire. Blythe $(1994,17)$ has argued that although most writers regard Maoriland as sentimental racism it can 'also refer to those many Maori attempts at reaching a conciliation with the expanding British-Pakeha nation', citing among other historical figures Ngāti Porou leader Āpirana Ngata. In response, Stafford and Williams (2006, 256-267) explore Ngata's poem A Scene From the Past (1894) as an example of a Māori person writing in Maoriland. In fact it has been widely noted throughout the arts that in the early twentieth century Māori were not only represented as stereotypes trapped within 'timeless' ethnographic Pākehā texts but many collaborated in and made use of Pākehā cultural artefacts for their own purposes (Blackley 1997, 44-55; Petersen 2000, 69-71; Gibbons 2002, 15; Diamond 2007, 18; Mita 1992, 36-39; King 2008, 2; Wanhalla 2011, 116).

Absent from this discourse of Maoriland is rigorous interrogation of Pākehā appropriation of Māori music and Māori response to this. As Johnson $(2010,6)$ notes, the unique cultural partnership between Māori and Pākehā as defined under the Treaty is 'barely represented' in a recent collection of essays on music and New Zealand identity. I see three reasons for this absence. Only recently have music scholars addressed Belich's (2001, 326-341) argument that an ignorance of the cultural context of early twentieth-century cultural artefacts exists because from the 1930s onward intellectuals effectively erased from the New Zealand's cultural memory all previous artistic attempts at defining the nation (Maconie 2006, Maurice 2006). ${ }^{8}$ Only recently too has it been asserted that Maoriland presents a challenge for today's Pākehā: 'Maoriland is taken to be a false dawn of national self-knowledge, an embarrassing colonial confusion about identity...' (Stafford and Williams 2006, 271). By interrogating Maoriland music Pākehā may recognise modern-day parallels and uncover 'embarrassing truths' about their current identity formations. Thirdly, in the present era of heightened cultural awareness, Pākehā mindful of the exploitative practices of earlier Pākehā researchers are hesitant to approach cross-cultural artefacts that

${ }^{8}$ See also Stafford and Williams' $(2006,13-15)$ discussion of the 'complete dismissal' of Maoriland writing by 1930s cultural nationalists such as Allen Curnow and Denis Glover. 
by this very definition hold meaning for both Māori and Pākehā. For these reasons Hill's 'Māori' songs have been neglected, his music for Rewi ignored, and the entire soundtrack of Maoriland forgotten. I hope that recognition of the fluid and imaginary nature of communal identities, and the following evidence of Hill's relevance to past and present Māori and Pākehā will encourage scholars to re-evaluate Hill's 'Māori' music.

\section{Thesis Structure}

Chapters One and Two explore the nationalist characteristics of Maoriland music and film. Chapter One summarises Hill's relationship with Māori people and his 'Māori' songs. It then situates these local songs within contemporary transnational nationalist music discourse and provides the brief example of Hill's 'Waiata Poi' to raise the issue of what language is appropriate to discuss songs that represent both Pākehā and Māori identities. It closes by extending this in-between context to other potentially nation-building sites. Chapter Three continues the theme of locally and transnationally constructed nationalist Pākehā texts in a discussion of the production history of Rewi and Hill's film score. Finally, aided by Hill's cues it presents a reconstruction of the film's original narrative and applies this to a brief review of criticism of Rewi.

Chapters Four and Five extend the notion of 'homes' as imagined communities. Chapter Four describes the cross-cultural composing circumstances of 'Home, Little Maori, Home' and discusses the many homes its subject inhabited between 1909 and 1940. The multiple identities embodied in Hill's 'little Maori' are then incorporated into an analysis of the song's use in Rewi as a love theme for real and fictional individuals and communities. In Chapter Five Hill's collected and arranged haka (posture song and dance) 'Song of the Locust' is introduced through a discussion of his part in the early twentieth-century climate of salvage ethnography. It is then analysed as a song that through its western musical stereotyping, Māori cultural allusion, and syncretic musical characteristics provides a vehicle for Hill to civilise the Savage in Rewi, and for Māori to reclaim a Māori song. 


\section{Chapter Two}

\section{'In-Between' Music: Alfred Hill's 'Māori’ Songs}

The sparse academic literature on the subject of Alfred Hill's 'Māori' music is bewildering. John Mansfield Thomson $(1980,189 n 1)$ argues that Hill's response to Māori music was warm and genuine and that he had an instinctive rapport with Māori, Mervyn McLean (1996, 313-314) acknowledges that in his own time Hill was considered 'if largely by default' an authority on Māori music and that his songs held significance for Māori performers, and Allan Thomas $(1981,27 ; 2011,12)$ hears Hill's 'Māori' songs as innovative bicultural music. In contrast Douglas Lilburn (1980, n.p.) considers Hill's interest in Māori music was transient and 'not deeply rooted in his psyche'; his use of it merely 'grist to the mill'. While Sarah Shieff $(1994,30)$ argues that Hill used Māori music as a 'colourful veneer over traditional western forms', and believes that he '...felt himself to be basically a British subject' (ibid., 223).

Hill's 'Māori' music elicits such strongly worded and contrasting responses because it represents the many in-between places in early twentiethcentury New Zealand where racialised imaginings are at times inseparable from genuine Pākehā admiration for Māori, and where Māori engage with Maoriland to imagine their own identities. This chapter begins with an overview of Hill's contact with Māori people and his 'Māori' songs, and then discusses his musical appropriation within the context of local Maoriland and transnational nineteenth-century musical colonialisms. Finally, using the example of Hill's 'Waiata Poi', it addresses the issue of language embodied in Hill's Maoriland songs and returns to the powerful site of 'in-between' music.

Hill, Hira, and Te Hiwi

Hill was born in Melbourne, Australia in 1869, the son of English immigrants. In 1872 the family moved to New Zealand encouraged by the positive account given of the country by Hill's uncle who had fought in the then very recent New Zealand Wars (Thomson 1980, 8-11). Hayward (c.1961) recalls that Hill was 'virtually brought up' on stories of these conflicts. Hill's formative musical experiences reflect this martial context and the racialised musical 
practices of the time. Introduced to the tambourine at the age of three he progressed to cornet player in the Wellington Garrison Band and then joined his brothers in their Christy Minstrel show (Thomson 1980, 12, 15). Next Hill began to learn under Rivers Allpress the violin, which with the viola was to become his main instrument, and he began to compose with the aid of harmony lessons taken with Mr Clutsam (ibid., 17, 20). Recognising his son's talent, in 1887 Hill's father sent him to study at the Leipzig Conservatorium from where he graduated four years later with a Helbig Prize (ibid., 22-23, 38).

In June 1890 Hill travelled to Scotland for a holiday and collected material for his 'Scotch' Sonata for Violin and Piano (Thomson 1980, 36). He dates his interest in collecting Māori music, however, from his return to New Zealand when he became inspired by a 'plaintive Maori melody' sung to him by journalist Ernest Hoben, which later turned out to be of Rarotongan and European origin (ibid., 57; 'Maori Music', Evening News (Sydney), 18 May 1911, 8). Hill ([1950s]) describes his reaction to hearing Hoben's performance: 'By Jove! Here's something novel. If I can't make a success any other way I might make it by this idea of developing Maori music'. Apparently he initially heard Māori music as financially motivated, self-serving cultural appropriation.

Late in 1892 Hill began to plan a Māori-themed opera and travelled to Auckland for a stay of several weeks hoping to find 'good local colour in the north' (Auckland Star, 8 December 1892, 3). Early in 1893 he had reportedly almost completed an opera on ancient Māori lore (Bay of Plenty Times, 24 February 1893, 4). In fact Hill premiered his first 'Māori' work the cantata Hinemoa (libretto by Arthur Adams), which incorporated Hoben's melody, on 18 November 1896. The Observer of 31 July 1909 reported that before Hinemoa's debut, 'for weeks at a time' Hill had lived at Rotorua, Taupō, and Ngāruawāhia, and in 1911 Hill mentioned he had collected music at Whanganui ('Maori Music', Evening News (Sydney), 18 May 1911, 8). Hill toured New Zealand during 1893 (Thomson 1980, 51), and he performed in Whanganui as early as July 1896 ('Mr Alfred Hill', Wanganui Chronicle, 11 July 1896, 2), however no details of the specific locations and informants from these early visits have yet come to light. 
Hill's direct contact with Māori during the early 1890s apparently altered his initial calculated response to Māori music, later recalling:

Arthur [Adams] wrote this legend [Hinemoa] and I decided to set it to music and the citizens of Wellington rather laughed at the idea that we could get anything from a lazy Maori, and at that time of course, you lived so near to the Maoris and there were so many about that they didn't think much of them, especially artistically. I said, you wait and see. (Hill 1952b)

As Hill remembers it he distanced himself from the prevailing Pākehā stereotype of the 'lazy Māori' and early on appreciated Māori music for its aesthetic value. Hill's re-evaluation of Māori music may have similarly influenced his audience. Thomson $(1980,58)$ credits the considerable success of Hinemoa with helping to change the negative perceptions that Pākehā held about Māori by arousing their interest in Māori traditions.

An example of the increased Pākehā interest in Māori culture at this time was the trend of assigning Māori names to Pākehā homes (Petersen 2000, 57). Under the advice of fellow lawn bowler Charles Parata (Ngāi Tahu), the Hill family named their private green in Island Bay, Te Hiwi (The Ridge) (Free Lance, 3 April 1909, 16). Hill's brother Edwin later named his Lower Hutt home Te Hiwi too (Hutt News, 17 November 1937, 6). Historian, journalist, and ethnologist James Cowan identified the Maoriland ideology underlying this trend when he described it as a 'craving for a home-name which shall be redolent of the soil' (Cowan quoted in Petersen 2000, 58). Pākehā may have been alerted to a Māori presence by Hill's Hinemoa, but they co-opted this presence to assert their own; indeed, Hill named his New Zealand-born daughter Elsa Hinemoa. Yet as Parata's collaboration above suggests, some Māori interpreted Pākehā interest in their culture as genuine admiration.

In the early twentieth century Hill continued to collect music from Māori when the opportunity arose. In 1904 J.C. Williams produced in Sydney Hill's opera Тари (1902, libretto by A Adams and J.C. Williams), which included haka supervised by Wi Duncan (Ngāti Kahungunu) and poi (dances performed with balls on strings) taught to ballerinas by the Panapa sisters (iwi affiliation unknown) ('Dramatic and Musical', Free Lance, 13 February 1904, 11). From one 
sister Hill collected five poi songs ('Maori Poi Songs', AHMM, box 35). In this period he also collected tangi (laments) and haka with the assistance of politically influential Māori such as Te Heuheu (likely paramount chief of Tūwharetoa, Tureiti Te Heuheu Tūkino V), Minister of Native Affairs James Carroll (Ngāti Kahungunu), Government Interpreter Henry Stowell (Ngāpuhi), and Member of Parliament Āpirana Ngata ('Maori Music', Press, 14 March 1908, 7). From Te Heuheu Hill collected the tangi 'No-te-ao te ua ra aha tanga', and from Ngata the tangi 'Whakarongo e te Rau', both sung at Prime Minister Richard Seddon's funeral in 1906 (respectively, ibid.; Hill 1951, 2).

In the early twentieth century Hill also actively sought out informants. From around 1904 he spent evenings in artist Charles Goldie's Auckland studio collecting songs from Goldie's models Wiremu Patara Te Tuhi (Ngāti Mahuta) and Ena Te Papatahi (Ngāpuhi), which he said were by then fifty or sixty years old (Thomson 1980, 81). There is also evidence to suggest that Hill collected music from Māori living in the model pā, Arai-te-Uru, erected at the 1906-1907 International Exhibition at Christchurch. Cowan's official account of 1910 includes song lyrics sung by 'Turakina schoolgirls' and Hill's manuscripts include an undated song with the same words attributed to 'Turakina maidens' (Cowan 1910, 338; 'Whakapukepuke', AHMM, box 35).

Hill also established a significant relationship with the Tūhourangi hapū (sub tribe) of Te Arawa located at the Rotorua thermal village of Whakarewarewa, although it is not clear exactly when this began. ${ }^{9}$ A photograph included in a 1950 interview for People Magazine ('Alfred Hill Maestro of the Maoris', 30 August, 39) shows Hill with two of his most treasured possessions: a taiaha (long wooden weapon) and an ornately carved hoe (canoe paddle). He is pictured holding the same hoe in the company of guide Makereti Papakura, her

\footnotetext{
${ }^{9}$ A relationship may also have existed between the Hill family and Ngāti Raukawa at Ōtaki in the early twentieth century. Edwin Hill and Ōtaki Māori performed 'Waiata Poi' together at several fundraising and interclub lawn bowls events (for example 'Island Bay Concert', Evening Post, 7 April 1914; 'A Splendid Outing [to Ōtaki]', Evening Post, 7 January 1929, 4). Hill's first wife holidayed at Ōtaki several times (for example 'Women in Print', Evening Post, 29 December 1914, 9). Hill certainly visited Ōtaki in 1925 (Ropata, 10 June 1952, AHPP, box 6) and that year collected 'Waiata Aroha' from Pirimi Tahiwi (AHMM, box 35; Hill 1926).
} 
sister Bella, and other members of Tūhourangi outside Papakura's house Tuhoromatakaka c.1909 (35mm-00480-a-F, JMTP; original in Hill Family collection), suggesting that Hill acquired it from members of Tūhourangi in 1909 and that he treasured their friendship always. ${ }^{10}$ This enduring admiration was mutual. The late Whakarewarewa guide Bubbles Mihinui knew Hill personally and held him in high regard, and members of Te Arawa still remember him today as 'Arapeta Hira' (Maurice 2006, 47).

Hill appreciated Māori use of the transliteration of his name. When two girls incorporated him as 'Hira', along with his unidentified friend Mohi (Moses), into the stick game song 'Titi Torea', he later published the song with special mention of the origins of his version's particular lyrics (Hill 1926, 10-11). He also signed the undated song manuscripts 'We are from Maoriland' and 'Maoriland' in the slight variation, 'Arapeti Hira' (AHMM, box 35). The first of these begins:

We are from Maoriland

Where grows the Kauri and

We'll make you Pakehas gay

For you will enjoy us

And long to employ us

To drive all your sorrows away...

These sentimental tourist-themed songs remained unpublished. Hill valued Māori use of his Māori name perhaps as signs of friendship and indigenous validation of his goal to 'save' Māori music, but his own attachment of it to songs that speak for Māori woman entertainers shows he also used it to sanction the Pākehā man's fantasy of the Maoriland maiden.

As a result of his initial intensive period of contact with Māori Hill wrote many 'Māori' songs between 1904 and 1910. Those he published individually in and shortly after this period are: 'Waiata Poi' (composed and published c.1904); 'Tangi' (1905); 'A Maori Canoe Song' (1908); 'Home, Little Maori, Home' (MS 1909, AHMM, box 35; published 1911); 'In Fairyland, A Maori Legend' (MS 1909, AHMM, box 35; published 1921); and 'Waiata Maori' (1917), which premiered in 1910 (Evening News (Sydney), 9 December 1910). 'Waiata Maori' is distinctive in

${ }^{10}$ Hill's relationship with Papakura is discussed in Chapter Four. 
that Hill describes the material - the waiata (song) 'Hoki, Hoki Tonu Mai' and haka 'Ka Mate' - as 'collected and arranged', although he does not attribute his sources.

In this period Hill also completed several instrumental works based on Māori narrative themes and musical materials. These include two string quartets: No.1 'Maori', begun while in Leipzig but revised after 1896 to incorporate Māori themes and material, including the melody from Hinemoa, and premiered in Sydney in 1911 (Dominion String Quartet 2007), and the programmatic No.2 'A Maori Legend in Four Scenes', composed between 1907 and 1911 (Lam 2006a). On 24 December 1910 Sydney's Evening News reported that Hill had completed the cantata Tawhaki (words from Alfred Domett's Ranolf and Amohia, 1872). Earlier this year he had premiered his 'Maori' Sonata No.4 for Violin and Piano (Evening News (Sydney), 5 April 1910, 1), with movements entitled 'Waiata Maori', 'Tangi' and 'Waiata Poi', afterwards arranging this for orchestra as Maori Rhapsody, which premiered 9 August 1913 ('Sydney Symphony Orchestra', Sunday Times (Sydney), 3 August 1913, 3). The extent of self-borrowing between these works requires further investigation.

In 1916 Hill became Professor of Harmony and Composition at Sydney's newly established New South Wales Conservatorium and settled into a career as art music composer and pedagogue. A decade later, however, his best-selling arrangement of 'Pokarekare' was published in New Zealand (see MacGibbon 2007, 94), and he travelled to America and England where he promoted Māori music. In Minneapolis Hill lectured on traditional Māori music and conducted his 'Māori' works (Thomson 1980, 175-176). In England he conducted Bournemouth Orchestra's performance of 'Tangi' and 'Waiata Poi', recorded his 'Māori' songs as a standard for rhythm and pronunciation, and arranged the publishing of 'Maori songs in a form suitable for popular gatherings' ('Women's World', Auckland Star, 19 October 1926, 21; Evening Post, 13 October 1926, 5).

Perhaps Hill was actually arranging the printing of his first collection Songs of the Maori (1926). In this he acknowledged the assistance of Ngata, Papakura, Pirimi Tahiwi (Ngāti Raukawa), and Stowell, however he also noted 
that the songs were arranged 'simply', 'primarily for the use of Maoris'. The prestige Hill gained from these marks of ethnographic authenticity and patriarchal benevolence likely reinforced his place as an authority on Māori music among non-Māori and enhanced his collection's commercial appeal, as suggested by the report that he had 'found a very encouraging demand for his songs, especially in the provincial towns of England' (Evening Post, 13 October 1926, 5). At home the director of music in schools, Mr E. D. Taylor, upheld Hill's assumed cultural authority and Maoriland ideology in his desire to see the 'genuine airs [of the collection] to which only a set music form has been given' distributed among primary schools ('Encouraging the Young to Sing', Evening Post, 6 January 1927, 8). Perhaps encouraged by the positive reception of these international lectures and performances, and the popularity of his collection, in 1929 Hill premiered in Sydney the opera, Teora (libretto by Hill).

During early 1930 Hill took leave from his position at the Conservatorium to compose a film score on location at Omori, Taupō, for a film on a Māori narrative theme directed by Hungarian American Alexander Marky. ${ }^{11}$ Hill's score includes arrangements of Māori songs and excerpts from Tawhaki, Māori Sonata for Violin and Piano, an unspecified 'Maori String Quartet', and Hinemoa (AHMM, box 22; Hill, 28 April 1930, AHPP, box 3). It is unclear what happened to Hill's music for Marky's film. On 19 September 1931 the Dominion reported that Hill was visiting the government film studios in Miramar, Wellington, to make final arrangements for the score. He also made tentative plans to travel to Los Angeles at Marky's request (Hill, n.d. AHPP, box 3). However, after Marky returned to America with a copy of Hill's score Hill never heard from him again (Thomson 1980 177). By the time the film was released in America in 1935 as Hei Tiki Marky's copyright on Hill's music had expired (Hill, 28 April 1930, AHPP, box 3), yet the film's orchestral score by Hollywood composer Oscar Potoker features arrangements of 'Tahi nei Taru Kino'.12 In Hei Tiki's hyperbolic press book Marky claimed to be 'an accomplished musician' who had collected the

\footnotetext{
11 Marky was also known as Markey.

12 The Māori songs in Hei Tiki are likely recorded by New Zealand sound-on-film pioneer Ted Coubray (see Coubray 1980).
} 
'traditional Maori melodies' within the score himself (Markey, c.1935), however he has been accused of plagiarism (Steven 1985).

In 1911 Hill had stated that, '...the work [of recording "noble waiata"], to be done well, would require time, and it would be necessary to live near the people to do it justice' (Evening News (Sydney), 18 May). During his three months on location at Taupō he got this chance. He heard Rihi Te Heuheu sing an old farewell song characterised by intervals he recognised as too small to notate (Hill 1952a), and he collected, harmonised and arranged the words and melodies of several modern songs including 'He Pao Aroha' and 'Tangi Whaiaipo' provided for him by Te Uira Te Heuheu (AHMM, box 35). ${ }^{13}$ In a contemporary interview Hill described another of his collecting and arranging techniques:

Fortunately the chief of the tribe in the picture [Hei Tiki] is a great lover of poetry and song, and it was our habit to exchange ideas on the subject. For instance, he would give me the translation of the words of a Maori song, and I would put it into English verse. Then I would take the same tune and write a different set of verses, which my friend the chief would put into Maori. (Evening Post, 7 May 1930, 13)

Perhaps this collaboration resulted in the Māori-themed songs 'Her Little Flaxen Skirt' and 'Sweet Maori Maid', which Hill was inspired to write while on location ('E Hine te Aroha e', Radio Record, 6 November 1931, 1-2). Māori did not necessarily consider these songs less valuable than his collected and arranged songs. In 1950 Mrs Mamaeroa Maniapoto (Tūhourangi) described the honour Hill's brother Edwin had afforded her by singing to her 'Sweet Maori Maid', promising to send him 'a greenstone' for his birthday (Maniapoto, 12 May 1950, AHPP, box 5).

Hill's time at Taupō rekindled his interest in Māori culture and his Maoriland imaginings, and boosted his creativity. He named his whare (house) beside Omori stream 'Te Hiwi' (35mm-00478-a-F, JMTP; original in Hill Family collection), and afterwards described his visit as 'one of the most delightful and stimulating experiences of my life' (Evening Post, 7 May 1930, 13). In 1931 Hill revived Hinemoa in Brisbane, finally premiered Tawhaki, and composed 'Te Rauparaha' ('Maori Music Composer's Visit', Evening Post, 17 September 1931,

${ }^{13}$ Rihi and Te Uira were sisters of Tūwharetoa paramount chief Te Heuheu Tūkino VI. 
15). He also published 'A Maori Lullaby (E Moe, e Tama, e Moe)' based on words by Wellington journalist and bowler Hori Makaire (23 October 1930, AHPP, box 3; 'A New Maori Song', Radio Record, 5 June 1931, 2). During this period Edwin Hill maintained Hill's public profile. He featured in a 1929 radio relayed Wellington concert of Hill's 'Māori' songs, performed by the Wellington Harmonic Society, 2YA orchestra, and Māori dancers from Ōtaki ('Hinemoa', Evening Post, 5 June 1929, 5), and in 1931 he provided an extensive biography of Hill for Radio Record (6 November), in which he emphasised New Zealand as Hill's 'mother country'.

Hill resigned from the Sydney Conservatorium in 1934 and the next year opened the Alfred Hill Music Academy; a venture that closed in late 1937 due to the effects of a fire and limited financial resources (Thomson 1980, 186-190). He may have considered relocating to New Zealand at this time. In 1936 Hill (17 June, AHPP, box 3) offered his help to the New Zealand Premier in establishing a National Conservatorium and expressed how Māori culture continued to influence his sense of 'New Zealandness': 'Anything that I could do to advise and help in this matter would be willingly done, in the interests of a country I love, and have always placed, from a Maori point of view, before the other outside countries'. In this year the Rotorua mayor offered Hill the directorship of a proposed conservatorium of Māori music and culture ('Centennial Plan', Evening Post, 15 September 1936, 14), and in 1938 John F. Woodward proposed Hill as conductor of a Centennial Exhibition symphony orchestra ('Correspondence', Evening Post, 2 December, 10). Intriguingly, on 20 April 1938 'Te Hiwi' wrote to the editor of the Auckland Star to suggest Hill as the ideal person to teach Māori school children how to sing Māori songs.

From late 1938 Hill spent a year in New Zealand while he completed and recorded his score for Hayward's Rewi. ${ }^{14}$ On his return to Rotorua he was welcomed at Ohinemutu by Reverend K. T. Harawira who reportedly said that although personally unacquainted with Hill he felt he had known him 'for a very long time through his interpretation of Maori life in music and his love and understanding of the Maori people' ('Maoris Welcome Composer', Rotorua

14 Discussed in the following chapters. 
Morning Post, 19 January 1939, 4, in AHPP, box 11). During this year Hill collected new Māori musical material, for example a lament from 'a descendant of Aeroa', Henrietta Travis (AHMM, box 35), and protested the 'Hawaiianisation' of 'pure old-time' Māori songs ('Real Maori Music The Hawaiian Overlay', Evening Post, 16 February 1939, 15). He also studied Māori music closely, discussing with a maker of kōauau (flutes) and 'principle character' of Rewi, perhaps Henare Toka, the instrument's tuning system wherein finger holes are stopped and re-bored at the performer's desire, later visiting Auckland Museum to confirm this information against their examples (Hill 1958, T1935). During this year Hill also advocated for a national Māori music and art competition (Radio Record, 3 March 1939, 12) and considered the directorship of the Rotorua Māori Choir (Rotorua Māori Choir Secretary, 27 May 1939, AHPP, box 4).

Between 1946 and 1958 Hill maintained a substantial correspondence with Phyllis Williams of Tolaga Bay on the subject of waiata (AHPP, boxes 4-7). A Pākehā, Williams collected Māori songs on the East Coast during the 1920s, and learned to speak Māori and sing in the Māori style (Robinson 2014). During the 1930s Ngāti Porou leader Materoa Reedy mentored her in kapa haka (cultural performance) and bestowed on her the honorary name of the eminent ancestress Kirimamae (ibid.). Williams sent Hill many Māori songs and discussed with him performance practice. She presented radio programmes on Māori music, discussing on one occasion 'Alf's Chant' (Williams n.d.), and in the early 1960s recorded Hill's arrangement of 'Whakapukepuke' as 'He Oriori' (Williams 1998). In 1951 Hill published Alfred Hill's Maori Album, his second and final collection consisting of three original songs, five arrangements of collected material, and on the back cover a transcription of the Whanganui and Ngāti Apa chant referred to by Williams above. Despite the collection's patronising title it includes iwi attributions and cultural information for the transcription and all songs.

Hill visited New Zealand for the final time in 1952 to conduct a concert of his own works including Hinemoa and the suite Scenes from Maoriland (Thomson 1980, 211-121). During this stay he delighted Māori children at Whangamarino School, Rotorua with a haka and once more advocated for a 
Maori Arts Institute (ibid.). He recorded his views on Māori music with Ashley Heenan (Hill 1952a), and may also have renewed his acquaintance with Hayward during this visit as on 23 July 1952 Hayward (AHPP, box 6) followed up with Hill his idea for a project on the legendary Māori figure, Maui. When Thomson (1980, 3) met Hill in Sydney in 1958 he found, '...a sprightly wiry figure, who sang snatches of Maori songs [and] broke into haka rhythms...' Despite his long-standing Australian residency and musical career, throughout his life Hill continued to visit New Zealand, collect and study Māori music, maintain relationships with and advocate for Māori people, and write and publish his 'Māori' songs.

\section{Musical Colonialisms}

Hill was inspired to write Maoriland music through direct contact with local indigenous culture, but he was also influenced by an imperial web of nationalist ideology. ${ }^{15}$ Referring directly to Anderson's theory of the origin of the nation, outlined in the Introduction of this thesis, Richard Taruskin $(2001,689$ 691) traces the relationship between western music and nationalism from sixteenth-century printed collections of distinctively local vernacular songs, through the rise of the public, collective patronage of Post-Restoration England and the political subtexts of Handel's oratorios, to the political nationalisms of nineteenth-century Italian Risorgimento culture and German Romanticism. Key to German nationalism was Johann Gottfried Herder's theory that as language is learnt in a community, and as there can be no thought without language then thought itself is a communal product (ibid., 691). Taruskin ties Herder's theory to music and the concept of authenticity:

When the concept of language is extended to cover other expressions of learnt behavior or expressive culture - customs, dress, art and so on those aspects will be seen as essential constituents of a precious collective spirit or personality. In such thinking the concept of authenticity - faithfulness to one's essential nature - was born. It became an explicit goal of the arts, not just an inherent property, to express the specific truth of the 'imagined community' they served and assist in its self-definition' (ibid.).

\footnotetext{
15 Ballantyne (2012) discusses colonial New Zealand as part of a dynamic web of empire.
} 
Within colonised countries this cultural nationalism became musical colonialism, which 'sought justification in the claim that [colonisers] could develop local resources better than the natives unaided...[and maintained] itself by manufacturing and administrating ersatz "national" traditions that reinforced dependence on the mother country' (ibid., 700). Antonín Dvořák's 'New World' Symphony (1893) is perhaps the best-known example of musical colonialism. Recently shown to contain an unrealised project on the subject of Longfellow's Hiawatha, it was intended as an 'object lesson to the Americans on how they might achieve a distinctive "school" of composition' by submitting 'American Indian' and 'Negro spirituals', as critic Henry Krehbiel related, 'to beautiful treatment in the higher forms of art' (ibid.). Hill and his early New Zealand audiences were familiar with international examples of musical colonialism, for example in May 1901 the Christchurch Musical Union performed 'Hiawatha's Wedding Feast' from Samuel Coleridge-Taylor's 1898 'Scenes from The Song of Hiawatha' ('Christchurch Musical Union', Star, 21 May 1901, 3), and in 1902 Christchurch Cathedral Organist J.C. Bradshaw performed a movement from the 'New World' Symphony ('Organ Recital', Star, 16 May 1902, 1).

Donald Maurice $(2004,21)$ notes that Hill's early string quartets 'bear a very distinctive Dvořákian flavor, perhaps with Maori influenced melodies replacing bohemian melodies'. Hill made a similar connection himself in comparing the 'New World' symphony to his Maori Sonata for Violin and Piano ('A New Maori Sonata', Evening Post, 1 April 1910, 2). Similarities between Dvořák and Hill run deeper than musical style, however. On 25 October 1904 the Auckland Star reported that '...[Hill's] work in connection with the development of his melodies of Maoriland, as shown in his cantata Hinemoa...entitle[s] him to the hearty support of all true New Zealanders' (emphasis added). And in an article in the Press on 14 March 1908 Hill urged Pākehā to find a home present in indigenous themes. In alluding to his own Hinemoa he urged young writers to 'develop the romantic dramatic motives of their own country, whose history is as picturesque as any that inspired Longfellow to write Hiawatha'.

New Zealand's musical colonialism has long been associated with the legend of Hinemoa and Tutanekai, stretching back at least as far as Alice 
Rowley's 'Hinemoa: Morceau Pour Piano: Descriptive of the Legend of Hinemoa as Recorded by Sir George Grey, K.C.B. (1889)'. Māori, however, not only provided narrative themes and musical material for Pākehā; they also performed and listened to these songs for their own purposes. Hill's Hinemoa appears to have had engendered a sense of ethnic identity for Māori contralto and composer Te Rangi Pai (Te Whanau-a-Apanui; Ngāti Porou), who reportedly said that in his cantata Hill had 'caught the true melody and the inner meaning of the native love song, battle cry, and chorus' (Auckland Star, 15 May 1906, 3). ${ }^{16}$ The layering of indigenous investment in Pākehā music written about Māori gives New Zealand's colonial music a unique cross-cultural character.

The Language of Maoriland Music

Can Hill's songs inspired by Māori culture signify an 'authentic' New Zealand and a Māori land? Are they Maoriland songs and Māori songs? A brief cultural analysis of Hill's song 'Waiata Poi' explores these questions and poses another.

The presence of Māori material in 'Waiata Poi' has long been debated (Thomson 1980, 82; Shieff 1994, 222; McLean 1996, 382n12; Maconie 2006, 41; Thomas 2011, 13). In later years Hill often related how the song's refrain came to him while watching a mouse run across Goldie's studio floor (for example Hill 1952b). However, the near monotonous section 'Kia rite...poi porotiti tapara patua' (Get ready...spin the poi, double strike) appears based on popular early twentieth-century poi instructions. Hill reportedly collected indigenous material for the song from Goldie's model Ena Te Papatahi (Press, 14 March 1908, 7), while Bubbles Mihinui (Tūhourangi) claimed that Hill wrote 'Waiata Poi' after watching Papakura and her sister perform poi at Whakarewarewa ('Inspiration for Famous Song', New Zealand Herald, 29 May 1968, 11). Mihinui's assertion is supported by Hill's manuscript example of an 'old and pure Rotorua poi song' reproduced in James Cowan's $(1907,109)$ guidebook New Zealand, or Aoteäroa, the middle section of which has nearly identical melody, rhythm, and poi instructions. The words 'Tikina e Hirini ki te rito harakeke' in the first section of

16 Te Rangi Pai (born Porter) was also known as Fanny Howie. 
Cowan's example, however, are identical to those Hill collected from Duncan in 1904 (Press, 14 March 1908, 7), and the words, rhythm and monotonous melody of the middle section are those which open Panapa's c.1904 'Maori Poi Dance No.1' (AHMM, box 35). ${ }^{17}$ 'Waiata Poi' does indeed include collected Māori material although the particular source remains obscure. As further research is conducted into Hill's 'Māori' music we may find it contains more indigenous material than we presently appreciate.

This cross-cultural song has a bicultural performance history. The popularity of 'Waiata Poi' among non-Māori is clear in its worldwide fame (Thomson 1980, 82-83), its twenty-six sheet music printings, and, as revealed by many early twentieth-century newspaper advertisements and reviews, its prominence on the programmes of local urban concerts. 'Waiata Poi' was popular among certain Māori communities too. Māori concert parties performed the song for forty years (McLean 1996, 314), and Ana Hato's 1929 Parlophone recording was one of her most successful (Hato and Waretini 1995, 14), remaining in the catalogue for two decades (Bourke 2010, 34). Although Hato (Ngāti Whakaue; Tūhourangi) and her cousin Deane Waretini '...admittedly sang in a modern idiom, they sang as Māori, not Pākehā' (Armstrong quoted in Hato and Waretini 1995, 9). If Hill's cross-cultural songs are songs of both Maoriland and a Māori land, what word or words can adequately describe them?

The slippery nature of the authorship, ethnic representation, and musical heritage of these songs together with the power inherent in naming makes them difficult to define. Archivist Meredith Lawn (2002, 298) categorises Hill's 'Maori songs' as a discrete genre within his oeuvre, however photographer James McDonald (7 June 1930, HMSP, folder 19) once enquired of Stowell: 'Did Alfred Hill or any Pakeha ever compose a Maori Song?' (emphasis in the original). Hill himself sometimes identified his Māori themed songs as 'Pakeha songs' or 'Pakeha-Maori songs' (for example 'Sweet Maori Maid' and 'Oriori [Mother is Weary]' respectively, AHMM, box 35). He divided his collected material between 'modern' songs and 'old', 'pure' and 'genuine' airs, and he sometimes described his arrangements simply by their Māori and European elements, for example 'He

17 Hirini is a transliteration of Sydney. 
Haka Ngeri' has the note: 'Tuwharetoa rhythm. Melody is for the English words' (ibid.). Developing a vocabulary to describe Hill's early twentieth-century crosscultural songs will no doubt only become more complicated as Hill's relationships with Māori, his collecting and composing methods, and early twentieth-century cross-cultural New Zealand musics in general become better understood, but this challenge must be met.

\section{Conclusion}

Hill was demonstrably nationalist in his outlook and his Hinemoa was part of a western tradition of high art musical colonialism, however, he is not remembered today as a nationalist or even at times a national New Zealand composer. Maurice $(2006,46)$ and Maconie $(2006,33)$ argue this is because in his 1946 address to the Cambridge Summer School of Music, now known as 'A Search for Tradition', Lilburn re-scribed New Zealand art music history, dismissing Hill's collected Māori material as acculturated music lacking the essential and 'pure' Polynesian qualities necessary in a folk music on which to build a national style (Lilburn 2011, 39-40). Lilburn's theme and (first) denunciation, like Hill's earlier murky attributions above, demonstrate that newly established sites of authority assert and validate their own position by expunging or minimising any previous such claims - but did Lilburn's words really stifle all of Hill's music?

Donald Maurice $(2006,48)$ says of the favourable reception of recent recordings of Hill's art music, 'the voice of the people has overturned a century of a collective and concerted effort to suppress the founding figure [of a New Zealand national musical identity]'. His mention of the popular voice brings to mind Anderson's argument, and Taruskin's application of this to music, that popular nationalism came into being when print capitalism enabled a large number of people to think about themselves in new ways. Indeed seven years after Lilburn's address, Harcus Plimmer $(1953,24)$ stated in New Zealand Country Magazine that, 'whatever the future holds, the music of Alfred Hill is assured of a notable place in the art history of New Zealand'. Clearly, the academy is not the sole domain of nationalist rhetoric or site of national identity formation. 
Likewise artefacts of musical nationalism are not confined to 'serious' nineteenth-century art music such as Hinemoa and the 'New World' Symphony. Michael V. Pisani $(2005,9)$ observes of white musical representations of Native Americans:

Musical nationalism in 'classical music' is often discussed as a largely nineteenth-century European phenomenon...but if we allow ourselves to remove conceptual boundaries between American classical and popular music...as well as boundaries established in the early twentieth century between folk and popular music, we see that nationalism and exoticism are persistent ideologies in the arts as well as politics.

Hill's 'Māori' songs work to represent identities, national and otherwise, in the powerful in-between spaces that form when a 'serious' composer writes art songs for select private and public performances that over time become popular commercial recordings and film music, when Pākehā write songs from appropriated Māori musical materials and narrative themes that are appreciated by both Māori and Pākehā, and when these cross-cultural, widely disseminated, and entertaining songs are retained and reinvented in cultural memory over several generations. But perhaps it is in the spaces between New Zealand's wars and popular historiographies of these conflicts such as Rewi that Hill's 'Māori' songs most powerfully describe the nation. 


\section{Chapter Three}

\section{'Let's build a nation': Rewi's Last Stand}

Rudall Hayward, the writer, director, and photographer of Rewi, grew up with the cinema. Born in England in 1900 he came to New Zealand with his family in 1905 as part of the theatrical company West's Pictures and the Brescians (Hayward c.1971). His father and uncle bought and converted Auckland's Royal Albert Hall to a picture theatre and by 1910 the family had a chain of thirty-two cinemas (Edwards and Murray 2007, 36). Hayward became a projectionist in 1918, worked for Beaumont Smith on The Betrayer during $1920,{ }^{18}$ spent a short time in Australia developing his skills, and returned to New Zealand to work on The Birth of New Zealand (Reynolds 1922) (Pivac 2011, 6364).

Sam Edwards and Stuart Murray (ibid., 36-37) divide Hayward's films into four types: 1) actualities or news items; 2) short fictional films, largely his 'communities comedies' (1928-1930), co-produced with his first wife Hilda; 3) social documentaries informed by his left-wing political views and sold to New Zealand schools, co-produced with his second wife Ramai; 4) features, including those with Māori characters: My Lady of the Cave (1922), Rewi's Last Stand (1925), The Te Kooti Trail (1928), On the Friendly Road (1936), and the subject of the present study. Edwards and Murray consider Hayward's feature films his major achievements within which he 'both visualized and examined many myths that underpin New Zealand society and history' (ibid., 38-39). These myths are nowhere more apparent than in his 1940 remake of Rewi.

Alfred Hill was almost seventy years old and had been writing his 'Māori' music for around forty-five years when he joined thirty-eight-year-old Rudall Hayward to make Rewi. Despite their generational difference, their appreciation of Māori culture and nationalist philosophies were similar. This chapter begins with a discussion of the influence of James Cowan, the Hollywood western, and

\footnotetext{
18 Perhaps Hayward's respect for Smith is reflected in the surname name he gave the Pākehā hero of Rewi, Beaumont.
} 
the notion of authenticity as the truth of national origin on Hayward's filmmaking practice. I then incorporate Hill's film score into a cultural analysis of Rewi's production and reception. Finally, adding Hill's cues to other evidence, I attempt a reconstruction of the original 1940 narrative, which I then apply to a brief review of critical literature of the film.

James Cowan, the New Zealand Western, and Destiny

Hayward's model for telling what he saw as New Zealand's 'rough island story' was the Hollywood western: 'When I saw all around me American films dealing with the history of their west I considered that New Zealand had material equally as fascinating' (Hayward quoted in Edwards and Murray 2007, 35). Hollywood westerns were very much part of New Zealand culture in the early twentieth century. American culture had arrived in New Zealand with New England whalers in the 1820s and continued with transnational transmission of American ideas, practices and technologies (Belich 2001, 251-252). In the twentieth century it came to dominate New Zealand's popular cultural forms such as music and cinema. For instance while in 1914 43\% of films screened in New Zealand (by value) were British and 32\% American, by 1927350 of the 400 films screened were American (ibid, 252). Film critic Gordon Mirams (1945, 125 ) identified the influence of American popular culture on New Zealanders at the close of World War Two: 'If ever a national post-mortem is performed on us, I think they will find there are three words written on New Zealand's heart ANZAC, HOLLYWOOD, and HOME...' ('HOME' meaning Britain).

With its close association with actual issues and events in American history, the Hollywood western is recognised as the most influential Hollywood film genre in helping to create a sense of American national identity (Benshoff and Griffin 2009, 105). During the American 'Indian Wars' between 1850 and 1900 the political ideology of 'manifest destiny', or the 'God-given right (and indeed duty)' of Americans to possess land was used to justify imperial expansion and indigenous assimilation or eradication (ibid., 104). Retellings of heroism in battles between U.S. Cavalry and Native Americans became codified as the 'western' genre, the thematic myth of which was the civilising of the 
western wilderness and 'wild' American Indians (ibid., 104-105). In his desire to define the nation Hayward adapted the myth of American manifest destiny to local history and racial attitudes.

Jock Phillips $(1983,533)$ has suggested that Hayward's desire to harness the powerful storytelling conventions of the western was influenced by the opening words of James Cowan's two volume official history, The New Zealand Wars (1983, 1:1); words which Cowan himself took to heart within his account:

The student of New Zealand history seeking for foreign parallels and analogies must turn to the story of the white conquest in America for the record of human endeavor that most closely approaches the early annals of these Islands [sic]'.

Cowan was born in 1870 and grew up speaking Māori on his father's farm near Kihikihi; a farm located on confiscated Māori land, which included the Ōrākau battle site (Colquhoun 2013). Over his lifetime he wrote thirty books, tourism publicity, and many magazine articles on New Zealand history and Māori culture (ibid.). He is best remembered today for his New Zealand Wars, in which his account of Ōrākau on one hand perpetuated the myth of racial harmony forged through Pākehā admiration for Māori bravery, and on the other included firsthand Māori oral histories of the conflicts (ibid.).

Cowan's influence on Hayward cannot be overestimated. For his first Rewi (1925) Hayward based his scenario on Cowan's history The New Zealand Wars and his story of Te Awamutu The Old Frontier (1922). He (Hayward, 13 December 192-, JCP) tempted Cowan's interest in his film by relating to him memories of reading Cowan's story of Pākehā-Māori Kimble Bent as a schoolboy, enclosing a company prospectus, and describing how Cowan's history was ideally suited to the screen:

It is certain that some of your literature on the subject is more fascinating than any American Indian tale and there is no reason why the picturesque adventure of the "Battling Sixties" in N.Z. [sic] should not be equally acceptable to the present Cowboy [sic] films from which the world wearies for a change. 
Cowan was then offered shares in the film company in return for his services as historical advisor, government go-between, and publicist (Maori War Films Ltd Secretary, 9 March 1925, JCP).

Reviews of the 1925 Rewi offer a snap shot of New Zealanders' attitudes to nationhood. One Auckland Star correspondent used the film as an example to rebut Bernard Shaw's argument that entertaining romance had no place in educative historical drama ('The Call of the Film', 22 November 1927, 6). The Auckland Star film critic cited Rewi among those films of the finest quality in which 'resides the true spirit of nations put there intentionally or unintentionally', a quality made possible by a cast made 'entirely [of] natives, who have succeeded in imparting to them the spirit of the peoples' ('Films of Nations', 28 February 1931, 5). It seems a film about New Zealand's history could succeed in educating the nation in nationhood if that history was transformed into a romanticised, sexualised, and authentic myth of origin.

\section{Cultural Sensitivity, 'Authenticity', and the Nation}

With the upcoming centenary of the signing of the Treaty of Waitangi, Hayward recognised 1940 as the ideal moment to reinforce the myth of Ōrākau with a sound version of Rewi. The narrative of this version focused more closely on the site of interracial conflict in the Waikato and an interracial love affair. Robert 'Ropata' Beaumont (Leo Pilcher), a Pākehā trader, and Ariana (Ramai Te Miha), the mission-raised daughter of a deceased Maniapoto noble woman and an absent Pākehā sea captain, are caught up in the historical events of the 1864 battle of Ōrākau. With racial tensions rising in the Waikato, Reverend Morgan (a historical figure) and his family leave their Te Awamutu mission station. As Maniapoto are reclaiming all 'half-castes' Robert smuggles Ariana out of the mission in a rolled mattress. After a love scene between the two, Robert loses a taiaha fight with Tama Te Heuheu, a fictional Maniapoto chief, resulting in Ariana's reclamation by her tribe.

On recovering from his fight Robert rides to Governor Grey in Auckland to deliver Morgan's intelligence report and then joins the Forest Rangers, a colonial militia, where he meets a man called Ben who may be Ariana's long lost 
father. Soon after, Robert returns to the Waikato to deliver Grey's warning to Māori of the consequences of their continued resistance. Temporarily reunited with Robert near her village Ariana is 'forced to choose' between him and her iwi. She decides, 'I cannot change what is in me' and joins Rewi Maniapoto and his followers inside Ōrākau Pā. The film concludes with a re-enactment of the three-day battle, including a version of the defenders' proclamation 'E hoa, ka whawhai tonu ahau ki a koe, ake, ake' (My friend, I shall fight against you for ever and ever), a show of Pākehā admiration for Māori bravery in the face of insurmountable odds, and Ariana lying seriously, perhaps fatally, wounded in her father's arms.

Hayward was in no doubt of the film's value as a nationalist text, suggesting in the theatre managers' press sheet (Frontier Films Ltd. c.1940): a window display made of the novel, Hill's 'Maori melodies', and period weapons and costumes; appearances by local New Zealand Wars veterans; and a 'Buy New Zealand Goods' campaign. He supplied Labour Prime Minister Michael Joseph Savage's quote 'Let's build a nation' and the Dominion's report of visiting Canadian film critic John Grierson's reaction at the film's preview in Wellington: 'it [is] more important that New Zealanders should have produced [this] film than that they should see a hundred films from Hollywood...because in [Rewi] the nation has expressed itself'. Hayward also alerted managers to Cowan's (1939a; 1939b), School Journal articles on Ōrākau and assured them that matinee performances had been endorsed by the Education Department. Nationalist ideology and practicalities came head to head however in Hayward's recognition of the racial divide in 1930s New Zealand society. He warned managers to not over-emphasise the 'Maori angle' and instead promote the film to Pākehā as a pioneer adventure. As for Māori audiences, he explained, they would already know about Rewi Maniapoto 'and iron bars won't keep them away'.

The extraordinary lengths to which Hayward went to present an authentic representation of the historical events surrounding the battle of Ōrākau are well documented by Jennifer Evans (1996). His use of historically accurate properties and locations was no doubt prompted partly by the desire to 
replicate the historical nature of Hollywood westerns. But Hayward went well beyond this when he chose actors who had close associations with historical figures. Raureti Te Huia, the son of Te Huia Raureti, a nephew of Rewi Maniapoto and Cowan's foremost informant on the battle of Ōrākau, played Rewi Maniapoto, while Te Rongonui Paerata, a descendant of leading figures in the battle played the fictional character Te Heuheu (Cooper 2013, 162). ${ }^{19}$ Other Māori actors were drawn from Maniapoto, Ngāti Ruakawa, Ngāti Haua, Ngāti Toa, and Ngāti Tūwharetoa, and Hayward had 300 replies to his advertisement in the local newspaper for Defence Force rough riders (Evans 1994, 20-21). This kind of authenticity, while not immediately obvious on screen, supported his rhetoric of nationalism.

Hayward sought financial security from an emotionally engaged local community. On 8 June 1937 the Te Awamutu Courier reported that he had screened excerpts from his 1925 production for the Te Awamutu Historical Society, and he reportedly stated that '...if he had the support and co-operation of the residents of this district both pakeha [sic] and Maori' he would go ahead. The Society 'had been founded in a spirit of intercultural collaboration and had instituted cross-cultural research practices', and while Pākehā members outnumbered Māori the most prominent Māori member was Te Huia, who was 'central to the Society's practice of local history' (Cooper 2013, 162). On 1 October 1937 the Courier reported that a Māori committee had formed to 'attend to a lot of detail work in which the Maori race will be prominent, to ensure accuracy...' Hayward and the Society soon afterwards formed Frontier Films Limited and the Courier of 1 July 1938 reported that members of the Society were 'strenuously and almost continuously engaged in assisting in the production of [Rewi]'.

As Diane Pivac (2011, 67-68) suggests, Hayward's approach to Māori cultural authenticity may have been partly motivated by his wish to rectify the cultural faux pas he had made during the production of his first Rewi when he had prematurely broken off negotiations with Te Puea Hērangi, the Kīngitanga leader at Ngāruawāhia, for actors to portray Waikato Māori, and instead

${ }^{19}$ Henare Toka played Tama in the taiaha fight scene. 
employed Te Arawa, however, well into production of the second Rewi in October 1938 he still planned to film the Waikato village scene using relatively inexpensive and well rehearsed poi teams at Rotorua (Hayward, 27 October 1938, AHPP, box 3). As with Hill, it is difficult to separate Hayward's genuine cultural sensitivity from his desire to affirm the nation, and these from the practicalities of maintaining a professional career in an underdeveloped section of the arts.

Despite Hayward's earlier miscalculation and his plans to film in Rotorua, in November 1939 Te Puea allowed Hayward to film the village scene at Ngāruawāhia and lent him the historic waka taua (war canoe), Te Winika (Ramai Hayward 1984). Perhaps Hill had a hand in Te Puea's change of heart. On 16 February 1939 the Evening Post reported that on meeting Hill, she had extended an invitation to him to research Māori music at Ngāruawāhia. Four days later Hill was part of a 140-strong party of anthropologists who received a welcome at Te Puea's dairy farm, and after inspecting the farm and her centennial waka building project were served afternoon tea and entertained with song and dance at Tūrangawaewae Marae ('Much Impressed', Auckland Star, 20 February 1939, 15). Alternatively, Hayward may himself have been involved in this last visit in his capacity as a newsreel cameraman. Further research may reveal a close link between actual and 'fictional' film segments of Waikato waiata and poi from this period, and provide additional evidence of Te Puea's engagement with Pākehā to promote her iwi's cultural revival.

It is unclear when Hayward and Hill first met. Hill had a lifelong acquaintance with Hayward's uncle Henry that may have begun at the 19061907 Christchurch International Exhibition, where daily entertainment was provided in the concert hall by the Exhibition Orchestra under Hill's leadership and the Haywards' Brescians (Cowan 1910, 380). ${ }^{20}$ In 1914 Hill's songs were arranged by the Haywards' Orchestra to accompany George Tarr's film Hinemoa (Press, 13 August 1914, 3). As local sound-on-film technology developed during the 1930s, Rudall Hayward approached Hill several times with projects. First he suggested a film of Hill's 'Maori opera', Hinemoa (Hayward, 14 September 1932,

${ }^{20}$ Perhaps Hill met a six-year-old Rudall Hayward at this exhibition. 
AHPP, box 3), imagining Hill's 'magnificent music sung by leading Maori choirs and soloists' (Hinemoa script, D5146.009.05, HC). Next Hayward suggested the subject of Domett's Ranolf and Amohia, using Hill's 'Tangi', 'Rotorua choirs', and '...the notes of a Maori flute heard over the water' (12 November 1936, AHPP, box 3). It appears Hill's responses to these clearly Maoriland-inspired projects do not survive. Despite Hayward's correspondence with Hill it was apparently the Secretary of Frontier Films, Mr Swarbrick, who encouraged him to contact Hill regarding Rewi (Hayward c.1961). Hayward (AHPP, box 3) wrote to Hill on 15 July 1938 sketching out the music required, and, ever budget conscious, suggested Hill could recycle some of his earlier film score while emphasising the limited technical facilities and funds available.

When Hill had written his earlier score for Marky he had romanticised Māori in a Pākehā narration of the nation:

The ambition of my life has been to write music which represents New Zealand properly, not a hotch-potch of Maori and pakeha [sic] to tickle the ears of groundlings, but something that would be worthy of the subject of the wonderful Maori people. (Auckland Star, 17 January 1930, 9)

When he arrived in Auckland in November 1938, however, there was a subtle change in Hill's nationalist rhetoric. The music for Rewi was to be 'true to life and to the times when the scenes were depicted - the war days in New Zealand' (Auckland Star, 26 November 1938). Hayward had earlier rejected as historically inaccurate Hill's suggestion of a watchman blowing a Pūtara (shell trumpet) from a watchtower similar to that seen in Marky's film (11 September 1938, AHPP, box 3), and Hill had obviously taken heed of Hayward's desire for authenticity. For his part Hayward (1940) acknowledged the effect Hill made on him at the time:

Alfred said to me one day, 'You know Hayward, we're only half this thing, the other half is the people of New Zealand - they should feel that this is their picture as much as ours'. Then I remembered what Bernard Shaw had said. 'Unless New Zealand learns to make her own talkies she will lose her soul! That's why I have made Rewi's Last Stand.

Hayward (1960) also recalled Hill's positive effect on Auckland's musical community: 
... I remember how all the Auckland musicians, when they heard he was coming, and when he did arrive and got amongst them, and how he was able to influence them. And very soon nearly all the musicians he wanted for his orchestra were keen to come and play under him.

On an unknown date the 1YA Orchestra recorded the music for Rewi in Hayward's Avondale theatre (Grefstad, n.d.). Hayward (c.1971) recalled that John Baxendale 'performed miracles on the sound side'; the music, for example, was recorded by hooking up the sound recorder to a belt projector. These conditions were much inferior to the 'playback method' recently introduced at Sydney's Cinesound Studio, where Hill's music for Ken G. Hall's 1938 Broken Melody had been recorded ('Operatic Scene for Film', Sydney Morning Herald, 5 November 1937,10$)$. It seems Hill was prepared to sacrifice sound quality to the larger aims of the project.

It is clear that Hill was one of a great many Māori and Pākehā cast and production team members who shared Hayward's drive for historical and cultural authenticity to uphold the myth of Ōrākau, suggesting that 1930s society was embedded with a strong nationalist sentiment, however, not everyone believed in this myth. Rehe Amohanga, Secretary of the Rewi Maniapoto Memorial Committee at the Otorohanga Māori branch of the Labour Party, wrote to Mr W.E. Parry, Minister of Internal Affairs on 8 February 1938:

...with all due respect to our ancestors Maori and Pakeha, the screening of such a Battle [sic] under the conditions which existed then would not be appreciated by the Pakeha, and I may venture to state by your Department...Our [sic] ancestors Blood [sic] spilt at Orakau we consider seriously as Tapu [sic], and to remain Tapu, the screening of such we strongly oppose...

On 9 March 1938 Parry replied that the government did not have the power to intervene, suggested the committee get in touch with Hayward directly, and reassured Amohanga that '...every care is being taken in the production of the film to avoid offence to either Maori or Pakeha, the desire of the producers to produce a historically accurate film'. With his more realistic sense of history, Amohanga implies that Pākehā would not want to see an unflattering portrayal of themselves, and objects to the filmic representation of deceased ancestors. The Minister, perhaps believing the prevailing myth of Ōrākau and that 
authenticity is a concrete concept overrides Amohanga's concerns and dismisses his view as the unrealistic one.

Rewi premiered at the Strand Theatre in Auckland on 12 April 1940. Three days prior the Auckland Star proclaimed:

\author{
TITIRO! TITIRO! [LOOK! LOOK!] \\ World Premiere of the most important, most dramatic, \\ most thrilling New Zealand film yet produced! \\ Rewi's Last Stand \\ ROMANCE! SWEEPING SPECTACLE! \\ MAGNIFICENT SCENES!

\section{HAUNTING MAORI MUSIC!'}

Newspaper advertisements show that the film toured in a roadshow from Auckland to Te Awamutu in May, to Wellington in July, and returned to screen in Auckland's suburban theatres and nearby towns from October 1940 until September 1941. There are no specific audience attendance figures for Rewi but its impact can be gauged from more general statistics. In 1939 Auckland's 235 theatres had 11,264,748 paid admissions ('Auckland Film History No.4', Auckland Star, 16 August 1941, 17), and at this time, when New Zealand's population stood at just over 1,500,000 the ratio of theatre seats to people was 1:6, contrasting with that of 1:12 in America (Mirams 1945, 6-8).

Reviews of the 1940 film were generally positive and perhaps not surprisingly, considering his publicity machine and contemporary wartime sentiment, reflected Hayward's nationalist agenda. On 13 April 1940 the reviewer for the Auckland Star identified the specific 'New Zealandness' of Hayward's western narrative of civilisation: Rewi marked a 'fitting note of progress' and 'cunning weav[ed] through it all an attractive romance of the fusion of Maori and Pakeha...enshrin[ing] the spirit of the two races'. Like the film's cast and crew, it seems New Zealand audiences readily accepted Rewi as an authenticated historiography of violent racial conflict dressed up as Progress. 


\section{Songs of Myth}

Hayward's narrative of Progress was supported by the very racialised constructions of Paradise it sought to suppress, and by Hill's Maoriland film score in particular. Hill's undated manuscript score for Rewi consists of thirtyfour cues arranged for orchestra with titles taken from Hayward's synopsis, in turn often taken from Cowan's history. These are nondiegetic cues that emanate from outside the world of the film and help to describe action, location, temporality, and characters' emotions. They include arrangements of several of Hill's 'Māori' songs: 'Home, Little Maori, Home', described by Hayward as Rewi's 'theme song' (Frontier Films Ltd. c.1940); 'Tahi nei Taru Kino'; the newly composed 'Oriori Mother is Weary'; and 'Song of the Locust'. Hill also used a motif made from 'The British Grenadiers' to represent British forces. Hill's cues do not account for several other orchestral pieces in The Last Stand, perhaps added in Britain.

The original film also included two of Hill's 'Māori' songs sung by Ramai Te Miha (Ngāti Kahungunu; Ngāi Tahu), although which these were and where in the film they appeared is unclear. Writing from England during 1946 Hayward (14 December 1946, AHPP, box 4) discussed with Hill his plans for his by then wife, Ramai Hayward, to record Hill's 'Oriori' and 'slumber song', to publish these with her photograph on the cover, and arrange her performance of them on $\mathrm{BBC}$ radio. Hayward (c.1961) later described one of these songs:

It was called Ore Ore [sic] and was sung by my wife Ramai Temeha [sic] and very beautifully sung too with a lovely counter melody weaving through the original theme. This melody was played by the cor anglais, which was an instrument that was very hard to get in Auckland at the time.

No arrangement of an 'Oriori' with cor anglais part exists among Hill's 'Māori' song manuscripts, but Hayward may refer to 'Whakapukepuke', and the slumber song may be 'Oriori Mother is Weary'; both were later published in Alfred Hill's Maori Album (1951), the cover of which does feature Ramai Hayward's portrait, according to a Hill family member (Alfred Hill's Maori Album, EHEP). ${ }^{21}$

21 The lyrics of 'Whakapukepuke' in this publication identify it as a version Hill had collected earlier (See AHMM, box 35; Cowan 1910, 338). 
Te Miha's songs are part of almost an hour's worth of material cut from the original 1940 release in London to meet British quota regulations for a second feature. Scant evidence exists for what the narrative of the original 1940 release was like. No complete script has come to light. The novel based on the synopsis is unreliable as scenes were cut late in production to reduce costs (Evans 1994, 20-21), and reviews do not provide detailed descriptions of the plot or Hill's music. Not all of Hill's cues apparently made it into the final cut (Hayward 1990, 15), and Hayward intended to re-record the music in England (Hayward, 8 September 1946, AHPP, box 4).

Despite these complicating factors, Hill's cues may prove to be valuable in reconstructing the original narrative. While it is probable that the sound was added to and partially improved upon in London ('Rewi's Last Stand' 1954, 45; Coubray 1980), it is doubtful that Hayward went through with his plans. Complete orchestral re-recording would have been an expensive undertaking for relatively little return during the time of significant personal and national post war economic hardship revealed in Hayward's correspondence to Hill during 1946 and 1947 (AHPP, box 4). In contrast to Hayward's early optimistic communications with Hill regarding the music, there is an absence of correspondence from him prior to the British release, and when the normally effusive Hayward arranged the return of the score to Hill he made no mention of re-recording (13 September 1949, AHPP, box 5). In later years Hayward (c.1961) described the film as having been 'chopped down' in England, 'and quite a lot of the musical material [went] with it...a great many of the musical sequences had to be dropped out'. The most compelling evidence in favour of the theory that the music was by and large not re-recorded, however, is the poor sound quality of the music in the extant film, an unfortunate feature of the original.

In assuming the music was 'chopped' and augmented rather than completely re-recorded, an idea of what is missing from Rewi can be ascertained by adding information from Hill's music manuscripts to incomplete production records, Ramai Hayward's recollections, and close reading of the existing film's editing. I believe the missing hour includes: two songs sung by Te Miha; shots 
from the mission departure scene (cue 2 fragmented); the fairies sequence from the forest scene (cue 4 missing); a large part of Robert's ride to Auckland (see Campbell 1986, 5; cue 7 cut short); a sequence from the Forest Rangers' camp scene in which Robert uses a taiaha to defeat a Ranger swordsman (see Hayward and Reed 1944, 91; cue 9 missing); and material from the Māori village scene (see Campbell 1986, 5). The greatest amount of material now missing appears to be from the battle scene (battle scene script, AHMM, box 22). Ramai Hayward (quoted in Campbell 1986, 5) explained, 'you couldn't expect Englishmen to want to see such an unsporting episode of English engaged in a battle where the numbers were six to one. Fully armed, and with cannon, against Maoris who were defending their homeland'. This battle material includes Māori digging trenches (cue 14 missing), a sequence of Ariana and the young boy Rimi in the trenches (cues 15, 16, and 17 missing; 'Film Friendship Lives Again', New Zealand Herald, 8 February 1985), Māori praying before the battle (cue 20 shortened), explosions and Māori suffering (cue 21 shortened, cue 21a, 22 and part of cue 23 missing), a re-ordering of the shots around Rewi's words of defiance (cue 27 replaced by part of cue 29), and shots from the final massacre (cue 30 fragmented).

In 1986 Russell Campbell (5) described Hayward's use of the myth of Ōrākau to uphold Pākehā ethnic and national identities: '[Rewi] 'obscure[s] a history of oppression...mask[s] contemporary inequalities, and by so doing...justif[ies] the presence of pakehas [sic] in Aotearoa and legitimize[s] the power that they wield'.22 Both Bruce Babington (2011) and Alistair Fox (2011) have more recently examined the entwined discourses of Progress and Maoriland within Rewi. Babington (2011, 241-242) explains:

For all his empathy with the defeated, it was impossible for Hayward to detach himself from the providential view of civilization's progress over savagery, which was so important to the settler self-image. But as with another ancestor of his fictions, the novelist James Fenimore Cooper, the victory, while celebrated, is shadowed with regret and nostalgia, evident in the new white indigenes' attempts to transfer some essence of the Maori to themselves by appropriating Maori symbols and language...'

\footnotetext{
22 Aotearoa is today the Māori name for the whole of New Zealand, although originally it likely described only the North Island (Belich 1996, 40).
} 
As Reid Perkins (1996, 6-7) notes, this Pākehā 'Māorification' is apparent in Robert's mastery of Māori language and adopted Ngāpuhi affiliation. Hayward, however, not only emphasises the home present by creating a Maoriland hero but also distances the settler home past. Captain Jackson of the Forest Rangers reassures Robert that he is has made the right choice of regiment with the comment, 'we don't stand on ceremony here, we're just plain colonials' (ibid.). The settler myths of homes past and present and those of Progress and Paradise converge in Robert's now missing victorious taiaha fight against the Ranger swordsman, where his 'native' skill is admired by Ensign Gustavus Ferdinand von Tempsky, a historical figure. Through this historically authenticated Maoriland rite of passage, the place of Robert and all Pākehā in New Zealand is cemented.

The original release emphasised racialised aspects uncomfortable to British audiences such as extreme violence against colonised people and Pākehā rejection of their home past, but curiously, it also presented unsettling representations of Māori for Pākehā. It seems the Māori community fought not as the Savages we see today but predominantly as Christians and, by this moral implication and as Ramai Hayward observes above, rightful defenders of their land. In missing shots Māori women sing hymns at the mission (Scenario 1937, 5146.005.11, HC), Māori pray before the battle, and Rewi rejects ritual sacrifice (battle scene script, AHMM, box 22). Robert's patronising metaphorical blow for Māori against a Crown soldier appears to endorse this mana whenua (indigenous territorial rights). To uphold the myth of Ōrākau, however, Māori must appear to transform from uncultured natives to civilised New Zealanders. It is Ariana's journey from superstitious Maoriland maiden to modern Māori partner of a Pākehā man that most clearly represents this process of conversion, and from the beginning Hill's 'Home, Little Maori, Home' reassures the audience that she will succeed. Meanwhile the Māori community's own conversion is not described by the complex society portrayed in the original release or by the overt and unreformed images of Savagery that remain today, but through Hill's treatment of 'Song of the Locust', which reinforces the Black-White warrior and Brown Briton stereotypes. 


\section{Conclusion}

In 1990 the magazine Te Iwi o Aotearoa ('Rewi's Last Stand' 1990) criticised Rewi for its 'distortion of historical facts', 'lamentable racism', and 'appalling acting', however, Māori filmmaker Merata Mita (Ngāti Pikiao; Ngāi Te Rangi) (1992, 43) reads Rewi as a somewhat sympathetic example of the colonised screen: 'The outrage that Hayward, and other historians since, felt about the injustice of the British advance is clearly evident in the film'. Had Mita been able to see Robert's Ranger fight, Christian Māori, and the extended, explicitly violent battle scene she would have seen an even stronger representation of injustice against Māori. In this light, the extreme lengths Hayward went to ensure cultural and historical authenticity complicates the hegemonic stereotypes of Maoriland. Rather than try to determine where 'genuine' cultural sensitivity slips into Maoriland imaginings, it may be more useful to see these as co-dependent but variously weighted elements of Pākehā identity formation.

Mita also regards Rewi as 'an engaging, high-spirited film, [which] ...is great to watch' (ibid.). Her surprising response may be an example of recent recognition that Pākehā images of Māori 'inhabit two realities' (Stafford and Williams 2006, 274). 'From the earliest times' Māori incorporated photographic images into Māoritanga (ways of being Māori), and the privileging of images of Māori by Māori only intensified with the development of film (Mita 1992, 39). The value of historical filmic images of Māori for Māori is obvious in Steven's 1985 documentary Adventures in Maoriland: The Making of Hei Tiki, where children of the star, Ngawara Kereti (Te Arawa), are delighted to see their mother as a young woman, despite Marky's dubious dealings with Māori during the film's production. I suggest that, like early Pākehā photographs and films of Māori, Hill's Maoriland songs are not only artefacts of colonial hegemony and genuine expressions of cultural sensitivity, but also taonga (treasures) that record indigenous engagement with the colonial regime and reveal personal histories of Māori performers and audiences. In the following chapters I consider Hill's Maoriland songs in Rewi as music that inhabits these two realities. 


\section{Chapter Four}

\section{Singing Māori Home: 'Home, Little Maori, Home'}

Secluded in the forest, Ariana looks up shyly at Pākehā hero Robert, and to the strains of 'Home, Little Maori, Home' she asks, 'Will the war mean the end of our - friendship?' 'No, why should it?', Robert replies. Later while hiding from a Māori war party, self-assured Robert plans Ariana's future: 'Come away to the Morgan's and be safe', but the racially conflicted Ariana is not so sure: 'Māori women fight beside their men, don't they? What would they think of me, a rangatira?' As a reprise of 'Home, Little Maori, Home' concludes she finally decides: 'I can't change what is in me...tonight we are lovers, for us there can be only now'. In denying Robert's protection Ariana has apparently made a fateful decision; one that will bring her much suffering and possibly her own demise.

By 1940 New Zealanders had been singing Māori home with Hill's song for thirty years. Over this period the Māori subject of 'Home, Little Maori, Home' came to represent various individual identities and imagined communities of ethnicity, race, gender, and nation. While the younger generation less familiar with this song may have heard the love theme of Rewi largely as the sound of Hollywood romance, those in their fifties may have remembered the joys and anxieties of personal or public interracial or Māori love affairs in times of peace or war. In this chapter I discuss the song's cross-cultural composing circumstances, its many cultural contexts between 1911 and 1940, and finally I return to Rewi to examine how through music Ariana both shoulders and throws off the burden of Hayward's desire for a racially integrated nation.

Waiata Aroha, Makereti Papakura, and the Maoriland Maiden.

Hill wrote 'Home Little Maori Home' during his intensive period of Māori music collecting in the early 1900s and although it apparently does not include collected material its composing circumstances must be considered within this cross-cultural context. On 31 July 1909 the Observer reported that Hill had travelled from Wellington to recuperate from a severe illness at the Auckland home of Harry Philcox, however by November that year he was well enough to 'compose several numbers in which [Maori airs were] embodied, and so 
preserved' (The New Zealand Herald, 6 November 1909, 4). Hill composed 'Home, Little Maori, Home' later that month (AHMM, box 35), published it with English lyrics in 1911 as 'Home, Little Maori, Home: A Maori Love Song', and on an unknown date produced a separate printed slip with Māori lyrics, a pronunciation guide, and the subtitle 'Waiata Aroha'.

Hill's Māori subtitle literally translates the English one but also suggests this song is somehow characteristic of waiata. Mervyn McLean (1996, 110-113) defines waiata as group songs of ritual encounter that support a speaker with appropriate words. Waiata aroha are closely related to waiata tangi (songs of lamentation) as the word 'aroha' not only means love but also pity and sympathy, and in this way both can be considered songs of yearning, although waiata aroha are usually composed by women (ibid., 114). Musical characteristics of waiata include: a melodic range of a fourth or less; melodic intervals of major and minor seconds and minor thirds; a tonal centre near the middle of the scale; a strophic form in two phrases, the end of each strophe marked by the leader's final prolonged melismatic syllable, or 'hīanga'; and a 'terminal glissando', or whakaū, of a descending third or fourth (McLean 1996, 256; McLean and Orbell 2004, 16). By this definition Hill's song is not characteristic of waiata.

Hill wrote his first 'Māori' songs at the time a new Māori song genre emerged, which combined Māori language with the music of pre-composed European songs. McLean $(1996,312)$ terms these modern waiata, 'songs in the European idiom'. Popular European songs of the time drew from nineteenthcentury song traditions of folksong, theatre and pleasure-garden song, broadside ballad, and lied (Middleton and Manuel 2001, 143). These are characterised by a form made of stanzas ending in a short refrain, and melodically and harmonically open and closed two- to eight-bar phrases. These characteristics, and the tendency toward the sectionalism of drawing-room ballads perhaps influenced by art song, are exemplified by Henry Bishop's 1823 'Home Sweet Home' (ibid.). Indeed, Edward Rangiuia's adaptation of 'Home Sweet Home' was popular at this time and published in Hone Heke and Ngata's Souvenir of Maori Congress, July 1908 (1908) (McLean 1996, 317-318). The waltz metre was popular for these modern waiata (McLean 1996, 274). Arguably the best known 
example is 'Haere Ra (Good-bye) Waltz Song' by Erima Maewa Kaihau (Ngāpuhi), a 3/4 adaptation of the 4/4 'Po Atarau', itself an adaptation of Australian Clement Scott's 'Swiss Cradle Song' (1913), and later adapted to 'Now is the Hour' ${ }^{23}$

A Hill family member implies musical and cultural similarities between 'Home Sweet Home' and 'Home, Little Maori, Home' in remembering them performed together at home (Hill 1939b), and Hill's song does share some characteristics of modern waiata. Musically. It has harmonically open and closed phrases of even length, a wide melodic range, a piano accompaniment that provides harmony and doubles the melodic line throughout, and a form made of two verses in $4 / 4$ and a refrain in 3/4 that recalls the lullaby. The lullaby was a popular theme for modern waiata, for example Te Rangi Pai's 'A Maori Slumber Song, Heine [sic] e Heine' was published c.1911. Hill's song also uses Māori language. As in 'Waiata Poi' Hill keeps the most important words, here 'aue', in Māori within the English version, and his separate Māori lyrics assume a Māori performer, or a Pākehā one interested in the notion of bicultural practice.

Aesthetically, 'Home, Little Maori, Home' can be considered a modern waiata aroha. Its sentiments of aroha and tangi are expressed particularly through the word 'aue'. Hill footnotes this simply as 'alas', but it is sometimes uttered as an onomatopoeic wail of anguish. I would suggest that the rocking mezzo forte 'a-u-e!' and its pianissimo echo are reminiscent of the melodic inflections and spatial quality of the kaikarangas' (women callers) call and response across the marae (village meeting space) at the beginning of pōwhiri (welcome ceremony), appropriate in a song that describes a longed for reunion. This homecoming is expressed musically in recuperation of the refrain's pentatonic melody by diatonic harmony at the end of each eight-bar phrase. While the Pākehā performer's use of 'aue' can be considered a sign of his 'Māorification', and its accompanying pentatonism an allusion to the exotic other, it is also implied that his pain of separation is so acute that it can be communicated to his Māori lover only through her own culture.

${ }^{23}$ Annabell $(1975,233-270)$ provides biographical information for Kaihau, born Louisa Flavell, and the complex history of 'Now is the Hour'. 
The Auckland Star's reviewer (18 March 1911) described the drawing on the cover of 'Home, Little Maori, Home' as a 'typical Maori scene' (figure 1 below). The image shows a barefoot Māori woman wearing a pendant and chiefly kahu kiwi (kiwi cloak) with white pigeon feather trim, holding a patu (club), possibly a mere (greenstone patu), across her waist. She stands in front of a simply framed scene made of open ground, carved whare, cabbage trees, and in the distance, another building. Stafford and Williams $(2006,11)$ argue 'While drawing on the conventions of romanticism, [Maoriland materials are] also filtered through colonial ethnology to give [them] an air of authenticity and ownership'. The nameless Māori woman below standing as if on stage against the backdrop of her apparently pre-European home can be seen to represent this colonial authority in its ethnographic vision of the Maoriland maiden thrice contained: a theatrical imitation of life, a dying race, and a preserved relic.

This particular Māori woman, however, may well have a name. One of Hill's descendants believes she is Makereti (Maggie) Papakura ('Home, Little Maori, Home', EHEP), an assertion supported by the striking similarity between this figure and a contemporary photograph of Papakura (Partington c.1910). Papakura was born to Pia Ngarotu Te Rihi (Ngāti Wāhiao of Tūhourangi) and English ex-Waikato militiaman William Thom (Diamond 2007, 21-23). As a descendant of chiefs she was initially raised in the Māori world before receiving an 'exemplary' European secondary education (ibid., 14). Papakura came to Whakarewarewa in c.1893, was celebrated for guiding famous people including the Duke of Cornwall and York, and moved to England to marry Richard StaplesBrowne in 1912 (ibid., 39, 55, 127). There she studied anthropology at Oxford University; her unfinished thesis, 'ostensibly a description of traditional Māori life' but actually a specific record of contemporary Tūhourangi culture, was posthumously published as The Old-Time Maori (ibid., 178). 
Dedicated to H.B.PHILCOX ESQ

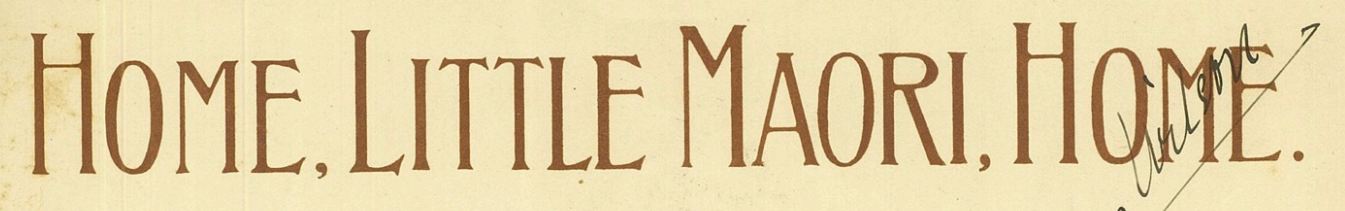

A MAORI LOVE SONG.

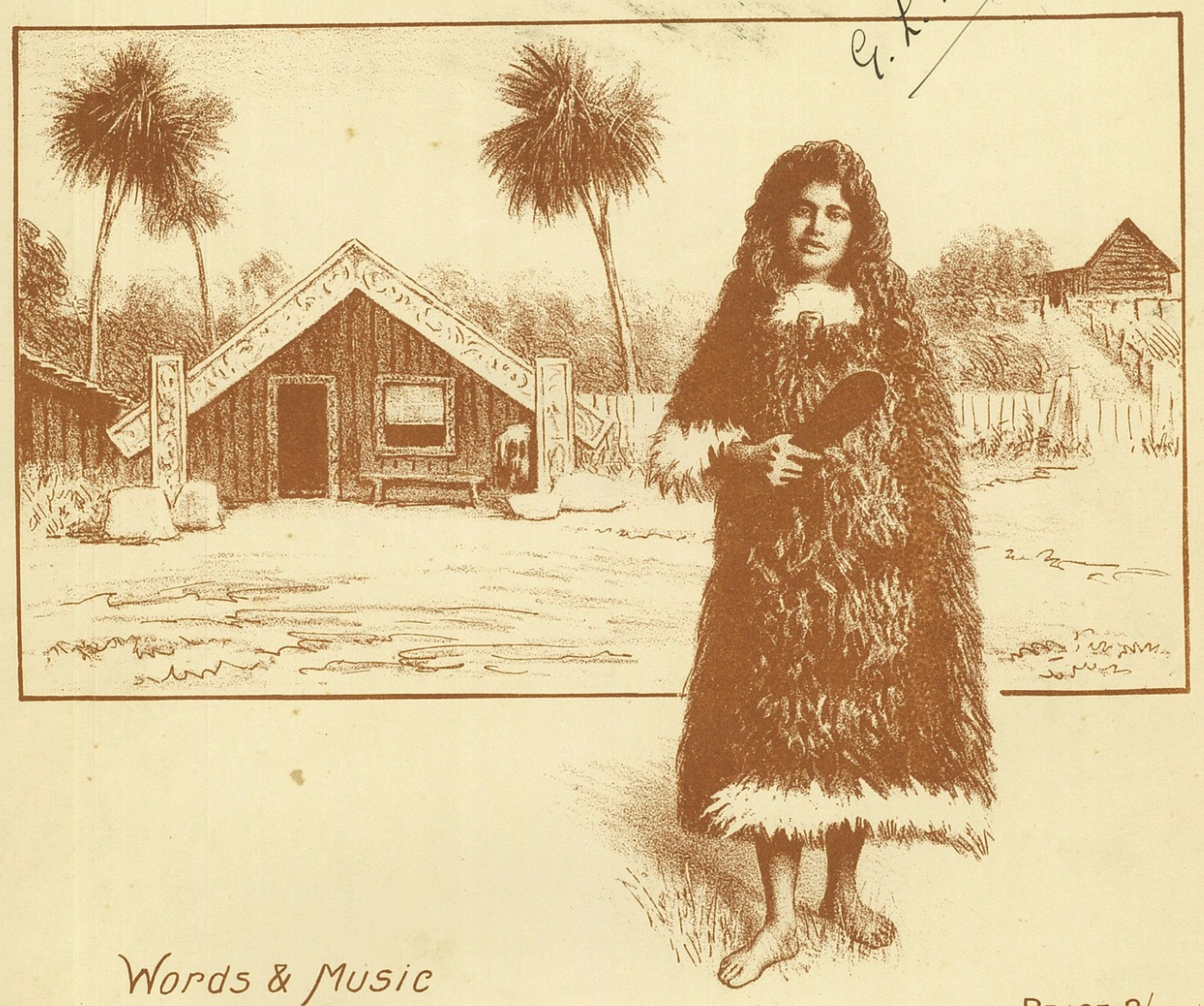

By

PRICE 2/-ner

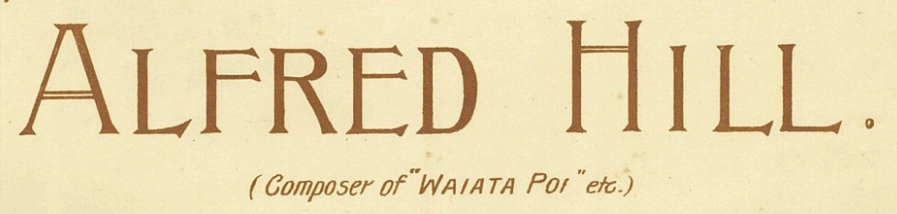

$$
\begin{gathered}
\text { A. EADY \& CO } \\
\text { IIZ, OUEEM STREET, } \\
\text { AUCKLAND, N.Z. } \\
\text { Copyright, MCMXI, bY A. Eady \& C? }
\end{gathered}
$$

Fig. 1. Home, Little Maori, Home. 1911. A. Eady and Co. 
Papakura and Hill appear to have had a significant relationship around the turn of the twentieth century. It is not clear when this began but interestingly Papakura arrived at Whakarewarewa about the time that Hill began seeking out Māori music. If not then, it seems certain they would have met when Hill visited the model pā at the 1906-1907 Christchurch International Exhibition where Papakura and her sister Bella were leaders of the Te Arawa entertainment troupe in residence (Cowan 1910, 308-352). Papakura's letters to Hill during 1909 show she shared Hill's desire to preserve Māori music, supported his writing of 'both Maori and English' songs, and predicted that when published with a dedication to her, a new unidentified song would sell 'like wildfire' (Papakura, 21 and 26 October 1909, AHPP, box 2). Just prior to the date on which Hill composed 'Home, Little Maori, Home' he travelled to Rotorua to assist Papakura's troupe, which was soon to depart for an international tour (Hot Lakes Chronicle, 10 November 1909, AHPP, box 10). Perhaps his original lyrics, 'oh why dost thou gaze only, on that far distant shore?' relate to this imminent event.

If the figure represents Papakura then the kāinga (village) is Whakarewarewa, a place where non-Māori have long been invited to experience Māori culture. The particular characteristics of Tūhourangi manaakitanga (hospitality) have been traced back to the kindness shown by Tama Te Kapua to his reluctant guest Ngātoroirangi during the Te Arawa migration voyage (Schuster, 2012). For Hill and perhaps a circle of knowledgeable family, friends, and colleagues of the time I suggest this cover represented a visual dedication to a respected friend and her welcoming hapū. Papakura offered Hill the permanent position of choirmaster of the Arawa troupe on their overseas tour (Papakura, 30 November 1909, AHPP, box 2), but this plan 'didn't come to anything' and it seems after 1910 they lost touch. When published, Hill dedicated 'Home, Little Maori, Home' to Philcox, and the lyrics regarding a Māori woman's overseas travel were altered to create a generic theme of separation suited to broad commercial appeal.

On one hand, the subject of 'Home, Little Maori, Home' was constructed and received as a Maoriland maiden; the ethnographic authenticity of her 'old- 
time' costume and setting can be seen as part of a wider appropriation of Māori culture by Pākehā that upheld colonial authority. In this context Hill's lullaby theme and paternalistic term 'little Maori' can be heard to ease Māori into their Pākehā-constructed home past and condone the Pākehā home present. On the other hand, the subject of Hill's song likely represents his affection for a highly esteemed Māori woman and her hapū, and his acknowledgement of Māori at Whakarewarewa as a vibrant community. This acknowledgement, and the song's cross-cultural musical influences, indigenous narrative theme, and bilingual lyrics, particularly the word 'aue', may explain why 'Home, Little Maori, Home' appealed to both Māori and Pākehā over the next thirty years.

\section{Sentiment, War, and Rikihana Carkeek}

As a Maoriland maiden, the subject of Hill's 'Home, Little Maori, Home' represented the indigenous subject of songs of both European art and popular concert traditions. In the contrasting themes of their programmes, these concerts influenced the Pākehā sense of homes past and present respectively. The repertoire of New Zealand choral societies, well established by the beginning of the twentieth century, 'faithfully echoed the taste of Victorian England' (Thomson 1980, 19). In this context Pākehā performed 'Home, Little Maori, Home' at concerts with non-Māori themes such as Edwin Hill's performance among a programme of English songs in its year of publication (Evening Post, 13 July 1911, 2), and Mr R. Kiely's performance in 1913 at a Greymouth Liedertafel concert (Grey River Argus, 28 May 1913, 5).

Pākehā also performed 'Home, Little Maori, Home' at locally themed variety concerts. At the Wellington Opera House in 1913 Hill's student Marcelene Boulais sang the song alongside his 'Waiata Poi' and 'Little Maori Girl' ('Entertainments', Evening Post, 18 September 1913, 3), while in Gisborne it was included as a “"picture song” with native girls' on the Vaudeville Company's programme alongside 'Waiata Poi', a square dance by 'Maori picanninies', and a poi dance ('Darktown Minstrels and Vaudeville Company', Poverty Bay Herald, 
29 October 1914, 8). ${ }^{24}$ It was attached to Pākehā imaginings of Māori more explicitly in a popular context when it was arranged as silent film music for George Tarr's Hinemoa (1914) (Poverty Bay Herald, 24 October 1914, 4).

'Home, Little Maori, Home' was also performed at public Savage club concerts (for example 'Ladies' Night', Dominion, 24 July 1911, 8). Local Savage clubs simultaneously recalled the home past by emphasising the myth of origin of the local clubs' links with the mid-nineteenth-century London gentlemen's club of the same name, and invented the home present through Oriental imaginings of the local Savage (Thomas 1998, 43-46). Local club rituals, which incorporated elements of appropriated Māori culture including language, traditional dress, and dance were seen by Pākehā as a homage to Māori traditions (ibid., 47-48). Hill was directly involved with the Wellington club as Musical Director from 1906 until 1909 (WSCR, 85-027-1/1), and he joined the Sydney 'hapu' when he moved to Australia (Savage Club 1930, AHPP, box 7). Although the Wellington club's public concerts did not have Māori themes, in the context of their 'koreros' (private meetings) where haka featured strongly, 'Home, Little Maori, Home' can be considered one of the many Māori motifs used.

While it is tempting to dismiss the Savage clubs' activities as racist, Allan Thomas (1998, 59) argues that the racial attitudes of early club members reflected those held more widely by both Māori and Pākehā. Māori engaged with early Savage clubs as haka instructors and makers of ceremonial regalia (ibid.), and a visit to the Wellington Savage club in 1908 by Ngata and a Ngāti Porou party from that year's Māori Congress was well received (WSCR, 85-027-1/1). Ngata's cultural exchange can be considered as an example of what Belich (2001, 214-215) regards as his 'brilliantly subversive co-operation' with Pākehā as a way to leverage financial and educational assistance for Māori people. Other than Ngata's group, however, all other visitors and members from these early years have non-Māori names suggesting a largely, possibly exclusively, Pākehā membership (WSCR, MSY-4399 and 85-027-1/1). As Thomas (1998, 60) notes, despite Pākehā homage and direct Māori influence, the Savage club was a site where colonial hegemony was displayed.

24 The Darktown Minstrels performed in aid of the Heni Materoa Children's Creche. 
Māori too used 'Home, Little Maori, Home' to represent various individual identities and imagined communities. Five months after Edwin Hill's 'family launch', Princess Iwa (Ngāi Tahu) performed it in London accompanied by 'twelve dancing girls' of Papakura's Te Arawa troupe ('Arawa on the Stage', Evening Post, 30 November 1911). ${ }^{25}$ Both performers and audience accepted Iwa's performance as representative of Māori culture, although exactly what that culture was differed. London's Daily Telegraph (quoted in ibid.) reported:

There is something particularly exhilarating...about the spectacle of the strangers, clad in their native costume, swaying to and fro...The picture is novel, pleasing, and touched with a certain primitive charm all its own...[Iwa's] touching rendering of two characteristic ballads was among the most delightful features of the evening.

Despite the European idiom of 'Home, Little Maori, Home', Iwa's exotic appearance rendered her song characteristic of 'primitive' Māori music. Perhaps this impression was enhanced by her choice of language - the review does not record this detail. For the audience, Iwa embodied the generic Māori (or perhaps generic Te Arawa) maiden of Hill's sheet music cover. Certainly the performers must have also felt this song represented themselves in some way to consider it appropriate for their programme, however, to assume because of this it represented a generic Māori community would be incorrect. This performance is an example of the popularity of Hill's songs among specific iwi who specialised in the custom of cultural entertainment, and who had a personal connection with Hill.

During World War One the subject of 'Home, Little Maori, Home' underwent something of a gender transformation in the form of members of the First Māori Contingent. This is made particularly clear in the memoir of Contingent member Rikihana Carkeek (Ngāti Raukawa) of Ōtaki. Carkeek was educated at Te Aute College and then worked for Parata \& Company in Wellington before joining the Contingent at the age of twenty-four (Carkeek 2003, 5-6). ${ }^{26}$ While encamped at Avondale prior to sailing for Europe the Contingent

\footnotetext{
25 Iwa was born Eva Skerrett at Stewart Island (McLean 1996, 324).

26 Carkeek fought at Gallipoli and in France, served as batman to Captain Peter Buck and was promoted twice. Returning home, he worked on the land and as an Interpreter for the Māori Land Court (Carkeek 2003, 5-6).
} 
gave a concert at the Auckland Town Hall where 'Home, Little Maori, Home' featured along side 'Hoki Hoki', 'Tipperary', and haka performances by Te Arawa and Ngāti Porou (New Zealand Herald, 5 December 1914, 7). Considering the predominance of Wellington-centred public performances of this song and its connection with Te Arawa up to this time, it seems likely that Māori from Ōtaki or Rotorua contributed it to the programme.

Carkeek's $(2003,20)$ diary entry for Thursday 25 February 1915, which records a stopover at Albany, Western Australia, reveals that Contingent members also sang 'Home, Little Maori, Home' as a group waiata for audiences while overseas:

...Albany at last!...At 3p.m. the contingent went ashore for a route march. We marched through the town to the outskirts to a great reception from the public. It's not a bad town at all. I spotted one or two Aborigines. We marched back and straight on board again at six thirty. There was a big crowd on the jetty. We sang 'Home Little Maori Home'...

Once in Europe the Contingent performed Māori cultural welcomes for visiting dignitaries. For instance on Saturday 3 April 1941 they gave a revue including 'a haka and welcome in the usual Maori custom' for General Maxwell and the High Commissioner of Egypt (ibid., 32). Like Te Arawa, the Contingent performed 'Home, Little Maori Home' as a group waiata for non-Māori audiences in the custom of manaakitanga.

Carkeek's memoir of World War One is in fact entitled Home, Little Maori, Home. The editors (Carkeek 2003, 5) shed light on the significance of this song for some Māori in World War One. Although the official policy was that the Māori Contingent performed only garrison duties:

...the reality was that Māori trained in battle on Malta, and fought and died at the side of their Pākehā comrades in Gallipoli and France. These young men remained stoic, sanguine and light hearted whenever the opportunity presented itself. Accustomed to death, they were unafraid of sentimentality. The words of the song, Home, Little Maori, Home, from which the title of this book is taken, evoke the spirit of that time.

It seems Carkeek did not consider the song's title derogatory, as we may feel today, and its strong sentiment was not rejected as Pākehā imaginings of Maoriland - although it was certainly this too. There were of course many 
European songs that expressed the grief of wartime separation, but to be able to sing of this in Māori must have given great comfort. Recognising this need, in 1914 Ngata published Songs, Haka and Ruri for the Use of the Maori Contingent, a collection of Māori lyrics set to European ruri (love ditties). With these modern waiata members of the Contingent living with the reality of imminent death could sing themselves home to a place of comfort and security.

On the home front 'Home, Little Maori, Home' continued to be performed in the Wellington region at public concerts, but now these gatherings were often organised in aid of the patriotic cause, and the song was regularly performed by Māori women as part of specifically Māori-themed programmes. For example between 1915 and 1917 Nurse Te Au of Ōtaki sang the song on three occasions: in English at the Wellington Town Hall; at the Rangitikei Jockey Club, where Edwin Hill sang 'Waiata Poi'; and at the Maniaia Town Hall (respectively, Evening Post 19 June 1915, 8; Wanganui Chronicle 4 April 1916, 7; Hawera and Normanby Star 21 April 1917, 8). The mention of Te Au's English performance confirms that Māori performers tailored their language to specific audiences. While these patriotic performances served the practical function of fundraising for soldiers and their families, many of the performers and audience members of the Wellington region no doubt had in mind particular Māori men they were missing. For them too the gender of the subject of Hill's song was redefined. It is somewhat ironic that Hill's original lyrics describing a 'distant shore', removed in the published version, would come to have national war time significance in the same vein as 'Now is the Hour' would during World War Two.

From these examples of early Māori performances of 'Home, Little Maori, Home' it seems apparent that this song helped to create a sense of belonging in the homes present of particular iwi, hapū, and martial communities. But Māori also used this Maoriland song to 'attempt [to] reach a conciliation with the expanding British-Pakeha nation' (Blythe 1994,17). This negotiation took place in the context of early twentieth-century Māori pageants. These were often organised by Māori and included 'Scenes of Maori Life' that told a colonial history of Māori 'evolution' from child-like innocence, through rebellious violence to noble subjugation, and finally to civilised fellow subjects of Empire; 
their place in modernity affirmed by their desire and ability to publically reflect on their racial maturity. For example, the programme for a pageant at the Wellington Town Hall on 26 July 1910 given by the Rotorua Maori Mission Choir and Entertainers, assisted by poi and haka parties from Ōtaki, Ngāti Huia, and Ngāti Porou, under the direction of Ngata and the Reverend Frederick Bennett (Te Arawa) ${ }^{27}$ proclaimed: 'THE MAORI AT HOME! AT PLAY! AT WAR! UNDER PAKEHA REGIME!' ('Maori Entertainment' 1910). A 'Grand Maori Entertainment' (Wanganui Chronicle, 12 March, 7) held at the Wanganui Opera House on 13 March 1918 featured 'Home, Little Maori, Home' as part of the opening scene, 'The Maori at Home'. In this imagined Māori home past, the song is used to work out the contradiction of the living 'pre-European' Māori and the early twentiethcentury ‘dying' Māori race.

In a pageant held at the same venue four months later directed by Charles Parnell and organised by Rangi Marumaru 'Home, Little Maori, Home' featured as one of three 'action songs' in the opening scene ('Delightful Maori Pageant', Wanganui Chronicle, 28 July 1919, 6). ${ }^{28}$ Removed from its context of colonial historiography, however, the Chronicle's Eurocentric commentator (ibid.) harnessed the song to a nationalist prescription for a Māori home present:

While the fascinating poi dance of the maidens, and the blood-curdling war dance of the warriors may be quite naturally regarded as the twin essentials to a successful Maori entertainment...it will, we think, be conceded that from the European point of view they do not constitute the most remarkable features of the excellent programme...all these are reminiscent of by-gone days: they symbolize as it were the customs and traditions of an ancient warrior race...the most pleasing entertainment is the high standard of musical culture attained by our younger Maori brethren.

For the writer, even though the haka and poi performances are the more popular items on the programme, clearly making them expressions of Māori culture of the time, they are reinterpreted as exotic old-time dances associated with

\footnotetext{
${ }^{27}$ Bennett, who later became the first Māori Bishop, strongly supported Hill's 'Māori' music. In 1914 he invited Hill to become the Rotorua Mission Choir's choirmaster and manager, told him the choir regularly performed 'Home, Little Maori, Home', and suggested he would be pleased with 'the Maori setting that we have arranged as a frame-work to your songs' (Bennett, 25 February 1914, AHPP, box 2).

28 The word 'action' in this programme likely refers to the song's dramatic setting rather than the song form waiata-a-ringa. See McLean (1996, 325-326).
} 
primitivism. It is youthful modern waiata that is married to civility. In this directive for a racially harmonious home future there is no room for tradition and innovation, the past and the present.

This prescription perhaps found a positive reception among the performers and audience of two representations of war presented at the second Whanganui pageant that reinforced the myth of Ōrākau (ibid.): a re-enactment of the battle of Ōrākau 'followed by the dancing of a spirited haka', and the tableau 'Victory' in which 'fifteen Maori maidens represented the nations concerned in the Great War, supported by a massed group of warriors in full war paint'. The pairing of each war scene with representations of the stereotyped Noble Savage reinforces the presence of indigenous New Zealanders in these wars, while the pairing of the battle scenes themselves helped to cement together the historical and contemporary conflicts as similar nation-building moments in the minds of New Zealanders, despite their very different political objectives and iwi representations.

The myth of Ōrākau, the sentiment aroused by the trauma of World War One, and the song's bicultural appeal produced a ready market for 'Home, Little Maori, Home' (see MacGibbon 2007, 94), and from 1918 it was republished in two editions: A. Eady \& Co. in three printings, and Arthur Eady Ltd 'The Old Firm' in two printings (Hill 1918a and 1918b, respectively). Both editions retain the original cover image although the woman's expression has been unsympathetically retouched on the engraving plate. In the latter, the original separate slip of Māori lyrics and pronunciation guide has been included and the Māori lyrics have also been engraved under the English lyrics of the song. ${ }^{29}$ This fully bilingual edition suggests an increased interest in the performance of this song by Māori, by Pākehā wishing to sing in Māori, and a desire by Hill to associate this song with the genre of modern waiata.

These two 1918 editions also have song samples by Maewa Kaihau at the back: the earlier 'May I Not Love', 'E Moe te Ra', and 'Akoako o te Rangi'; the latter omits 'May I not Love' to allow space for the page of separate Māori

${ }^{29}$ Māori lyrics have been added by hand on a copy of the earlier 1918 edition held at the ATL (Hill 1918c). 
language lyrics and pronunciation guide. Kaihau later wrote to Hill to express her regret at missing him on a recent visit he had made to Auckland, enclosing the Māori and English lyrics of 'a jilted maiden's waiata tangi' (Kaihau, c.1930, AHPP, box 3). The publication of Hill and Kaihau's songs together may reflect a mutual collegial respect, but it also implies that in practice little distinction was made between the ethnicity of the composers of bilingual songs at this time. This blurry 'racially harmonious' song genre, and 'Home, Little Maori, Home' within it in particular, no doubt reinforced for some Pākehā and Māori the myth of Ōrākau.

After World War One 'Home, Little Maori, Home' was performed in a greater variety of social contexts such as community concerts, Māori mission concerts, singing competitions, and League of Mothers gatherings (for example 'New Zealand Music', Evening Post, 8 October 1931, 12; 'Maori Mission Concert', Auckland Star, 16 October 1929, 21; 'Maori Songs, New Zealand Composers' Hawera and Normanby Star, 22 September 1923, 5; 'League of Mothers', Evening Post, 17 May 1938, 18, respectively). As in pre-war concerts, at many of these events the song was frequently mentioned in connection with Hill's other 'Māori' songs, especially 'Waiata Poi', however, unlike on earlier occasions, during the 1920s 'Home, Little Maori, Home' was often linked explicitly with national identity.

The ability of Hill's 'Māori' songs to influence narrations of the nation was enhanced through the technological advancement of public radio. From 1926 'Home, Little Maori, Home' became a regular item on the government radio stations of the four main urban centres, and on 6 February 1928 it was included in a special Waitangi Day commemoration programme on 2YA entitled 'History of the Maoris, Broadcast in Speech and Song'. Broadcaster Henare Te Ua (1996) observes of this particular programme:

Māori were no longer simply seen as able to provide the sort of musical entertainment that was radio's standard income earner at the time, but also that their form of 'entertainment' was unique to New Zealand and could help foster a sense of national consciousness. 
The programme featured lectures, recitations, excerpts from Ngata's Scenes from the Past, and 'Scenes of Maori Life' framed by and interspersed with movements from Hill's 'Maori' string quartet played by the Symons-Ellwood Quartet ('Over the Aerial', Auckland Star, 6 February, 1928, 6). Between the patronisingly entitled scenes 'Maoris at Home in the Early Days' and 'Maoris in Song and Play Today', Prime Minister Joseph Gordon Coates gave the speech 'The Maoris' Part in the Great War'. There is no mention of Ōrākau in this programme. In this propaganda New Zealand's history of internal racial conflict, mythic or otherwise, is sacrificed to the shared trauma of World War One.

This celebration of the present 'happy era of Maori-Pakeha brotherhood', as the programme described it (quoted in Te Ua, 1996), was very deliberately constructed through music programming. Echoing the aspirations of the Chronicle's reviewer above and exemplifying the changing stereotypes of Māori during the early twentieth century from Grey-White Māori to Brown Briton, in this particular colonial re-telling of Māori history 'ancient' or 'old-time' haka and poi are confined to the earlier scene. Meanwhile 'Home, Little Maori, Home' has 'evolved' from its nostalgic Maoriland home past to its place in the civilised Māori home present where as a modern waiata it joins 'Waiata Poi' and eleven other famous Māori songs of the day including 'Hine E Hine' and 'Home Sweet Home'. Further, Hill's instrumental 'Māori' art music and his popular 'Māori' songs are heard to represent his 'Māori music' oeuvre, and his 'Māori music' frames and 'infiltrates' music composed by Māori. There seems little doubt that in this context the Māori subject of Hill's song represents a Pākehā-imagined community of unified Māori and the home they are called to is the successfully integrated home present of a mature nation.

During the late 1920s international recording companies embraced the new technology of electrical recording and became interested in indigenous musics (see Bourke 2010, 33), further facilitating the dissemination of Hill's 'Māori' songs. The first commercial recording of 'Home, Little Maori, Home' was made in London in 1925 by Ernest McKinlay, a member of the World War One Kiwi Entertainers troupe (Columbia 3527; Auckland Star 26 December 1925, 18). Māori soldiers introduced McKinlay to Māori songs while they recuperated 
together at Narrow Neck Military Hospital in Devonport (McKinlay 1939, 155). During the 1920s he performed Hill's 'Māori' songs at Buckingham Palace garden parties (McKinlay 192-, AHPP, box 3), and in 1936 published his own collection, Maori Songs. In 1929 Ana Hato and Deane Waretini recorded 'Home, Little Maori, Home' in Sydney (Parlophone A-2805 (A-414), and alongside 'Waiata Poi' it was their most successful release (Hato and Waretini 1995, 14). The next year Tiawhi Ratete and the Rotorua Maori Choir recorded it in the Ohinemutu meeting house, 'Tunohopu' for Columbia (D0-67). Recordings from this occasion remained popular for thirty-five years (Bourke 2010, 35).

The presence of 'Home, Little Maori, Home' on programmes of benefit concerts for returned soldiers (for example 'RSA' Hutt News 15 July 1936, 4) and carillon performances at the National War Memorial in Wellington during the 1930s show in retrospect that Pākehā had also valued this song during World War One. The National War Memorial opened on Anzac Day, 25 April 1932 and the next day the Evening Post described the inaugural carillon performance:

...Thousands of people stood as if spellbound on the higher levels of Kelburn, Brooklyn, and Mount Victoria, listening to the music flowing out from the louvers in the tall tower and flooding the city with melody and harmony of indescribable beauty [...] As the listeners' ears drank in the sounds so their eyes were directed to the eloquent golden light shining out on the top of the tower and reminding all having eyes to see of the significance of this beautiful memorial to those who fell in defence of this land no less than for the Empire of which it is part....

This pride in Empire is reflected in a programme that included Irish, Scotch, Welsh, English and New Zealand songs including Hill's 'Maori Canoe Song' (ibid.). The next day and on many following occasions carillonist Gladys Watkins' commemorative programmes included 'Home, Little Maori, Home' (for example 'National Reunion', Evening Post, 16 October 1934, 10). This sentimental song of remembrance represented indigenous sacrifices to New Zealand and Empire for both Māori and Pākehā.

The subject of Hill's 'Home, Little Maori, Home' represented for Pākehā many identities. Initially, for Hill and his knowledgeable circle she likely represented the person of Papakura and the culture of Tūhourangi, and simultaneously the Maoriland maiden of a dying race. In 1911 she became the 
generic indigenous subject of European and New Zealand traditions of folk, art, and popular song evoking cultural memories of the settlers' homes past and present. For Māori the subject of this modern waiata aroha represented perhaps Papakura and Tūhourangi culture, but also Ngāti Raukawa, who at this time also performed for, and with, Pākehā in Wellington. Within large scale Māori pageants she negotiated between scenes of the past and present in response to Pākehā presence, and during World War One she involved Pākehā in the Māori war effort and stood in for men of the First Contingent.

After the bitter victory of World War One the various Pākehā and Māori individual identities and imagined communities embodied in the sentimental subject of 'Home, Little Maori, Home' were conflated with the myth of Ōrākau and strengthened through increased dissemination, commemorations of war, and nationalist government propaganda to create a sense of cross-cultural belonging in the nation-state of New Zealand, at times extended to Empire. This complex layering of meanings ensured that for many New Zealanders in 1940, irrespective of ethnicity and gender, and despite the impossibility of a consensually defined nation, the Māori of Hill's 'Home, Little Maori, Home' represented successful racial integration and an optimistic home future.

\section{Rewi's Last Stand: Ariana, Ramai Te Miha, and Intimacy}

Harmonious race relations were part of nationalist rhetoric supported by a Pākehā and Māori elite (Belich 2001, 206-215), but in reality Māori and Pākehā societies were largely segregated in the first half of the twentieth century. By the 1930s the Māori population had doubled from its nadir of 45,000 around 1900, however Māori remained marginalized: 80\% lived in rural areas, their land was of low economic value due to the depression, and their employment was largely seasonal or casual; conversely most Pākehā lived in towns (ibid., 466). Blythe (1994, 9) observes that most Pākehā texts from this time also practised segregation by devoting separate chapters, scenes, or entire works to Māori. Belich $(2001,466)$ argues, however, that this segregation broke down in the arenas of war, sport, and war commemoration, and I would add music. Rewi, as a film with a cross-cultural narrative and score that 'authentically' upheld the 
myth of Ōrākau and conjured cultural memories and lived experiences of, by the time of its release, two world wars, represented a very powerful site of imagined bicultural nationhood. ${ }^{30}$

Hayward accentuated Rewi's potential to describe the nation by boldly foregrounding the interracial love affair between Ariana and Robert. Although Māori and Pākehā communities were segregated in the early twentieth century, intimate relationships between these ethnic groups did occur and had done since the beginning of European contact. Under the colonial regime's initial policy of amalgamation sexual relationships were encouraged between Māori women and sealers and whalers in the forms of monogamous temporary or permanent common-law, Māori, or Christian marriages, and later in the nineteenth century relationships between Māori women and Crown agents were endorsed under a policy of assimilation (Wanhalla 2013, x, xii, xvi). However, with a rising fear of miscegenation, particularly between 1929 and 1940, mixed race marriages between any ethnicities came under severe scrutiny by the government and social reform groups (ibid., 135-138). While 1930s nationalist ideology encouraged integration society rejected lived experiences of interracial intimacy.

Hayward's decision to include a romance was influenced by the melodramatic theme of D.W. Griffith's 1915 Birth of a Nation (Babington 2011, 239). During the 1930s the genre of melodrama developed into the 'woman's film', which 'attempted to teach women lessons about their proper function under patriarchy. Women were constantly forced to realize their place as traditional mothers or housewives' (Benshoff and Griffin 2009, 229). In one variation of the woman's film the woman 'must choose' between her lover and a lonely career (ibid., 230). In the New Zealand context, free of Hollywood Production Code restrictions on the representation of miscegenation, Ariana and Robert's relationship becomes an 'allegory for the nation's future and its origins' (Blythe, 1994, 43). In a local twist on the Hollywood woman's film, Ariana, whose lack of surname obscures her ethnicity, 'must choose' between her

30 In 1940 'many' Māori actors from Rewi were with the 28th Māori Battalion in England (Hayward 1940). 
Pākehā lover and Progress, and the confinement of Paradise. This narrative conceit is emphasised in publicity material (Frontier Films Ltd. c.1940):

\section{WHEN THE WAR DRUMS ROLL SHE MUST DECIDE}

This lovely daughter of A [sic] Maori Chieftainness and a roving seacaptain - her's the most terrible decision that ever faced womankind

HOW WILL SHE CHOOSE!

Ariana's choice is also apparent in two publicity photographs for the film (figures 2 and 3 below). In the first, against a dark background Te Miha wears a korowai (cloak), subtle make up, a hei tiki, and feathers in her hair. She gazes downward with half-closed eyes, her turned head partially obscuring her face. The cloak worn across one shoulder reveals enough of her chest to suggest she wears no European undergarment, a long outdated practice in the Waikato by the 1860s (see King 2008, 74). In the second photograph, against a light background Te Miha wears a high-necked light-toned European dress, a white flower in her hair, and dark lipstick. Her open face gazes upward. Judith Butler (1999, xvi) argues that 'categories of race, gender, and sex '...always work as background for one another, and they often find their most powerful articulation through one another'. Here the chaste civilised Māori woman represents a wholesome home future, and the alluring Maoriland maiden, transgression.

These photographs of Te Miha share similarities with the re-drawn Māori woman on the final edition of 'Home, Little Maori, Home' (figure 4 below), likely published as a film tie-in (Hill 1939a). ${ }^{31}$ Perhaps trading on the longstanding popularity of this song, Hill's subject maintains the familiar stance and direct gaze of earlier editions, but her racialised sexuality is heightened. The extended pigeon feather border elongates her body, a lowered neckline and prominent hei tiki frame her partially exposed chest, and her straightened hair is secured by a headband to reveal shapely eyebrows and a lighter complexion. Taken together these images produced between 1911 and 1940 demonstrate the changing characteristics of the Maoriland maiden stereotype in popular Pākehā texts over the first half of the twentieth century.

31 Wolfe (1992) discusses later examples of a Maoriland sheet music covers. 


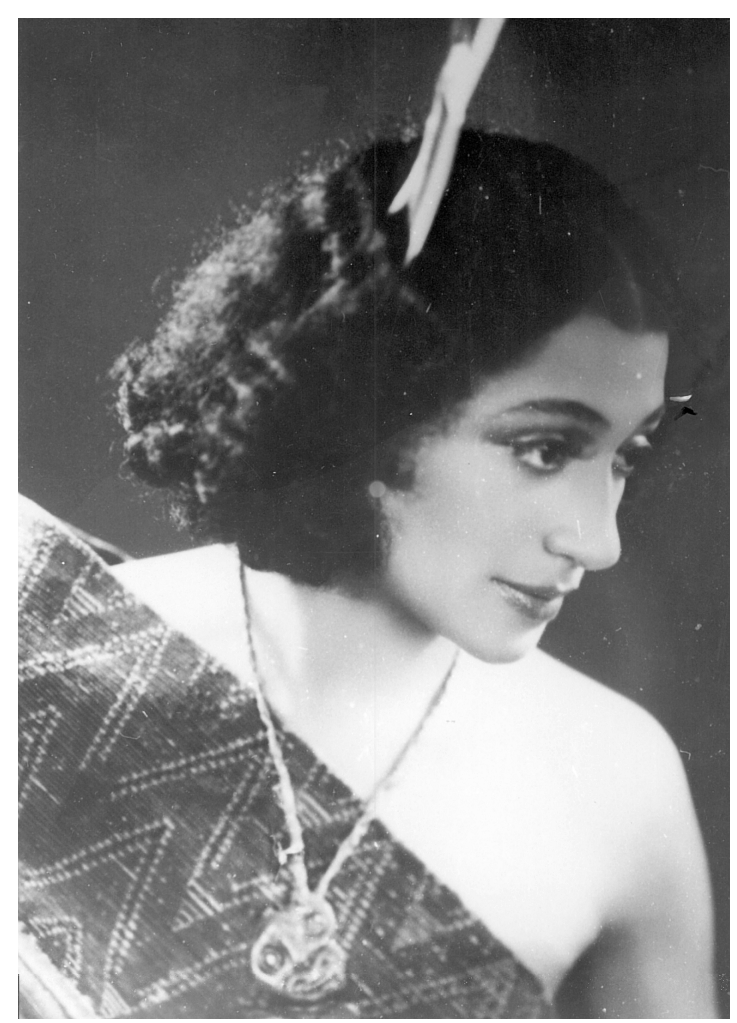

Fig. 2. Ramai Te Miha. c.1940. PH299. TAM

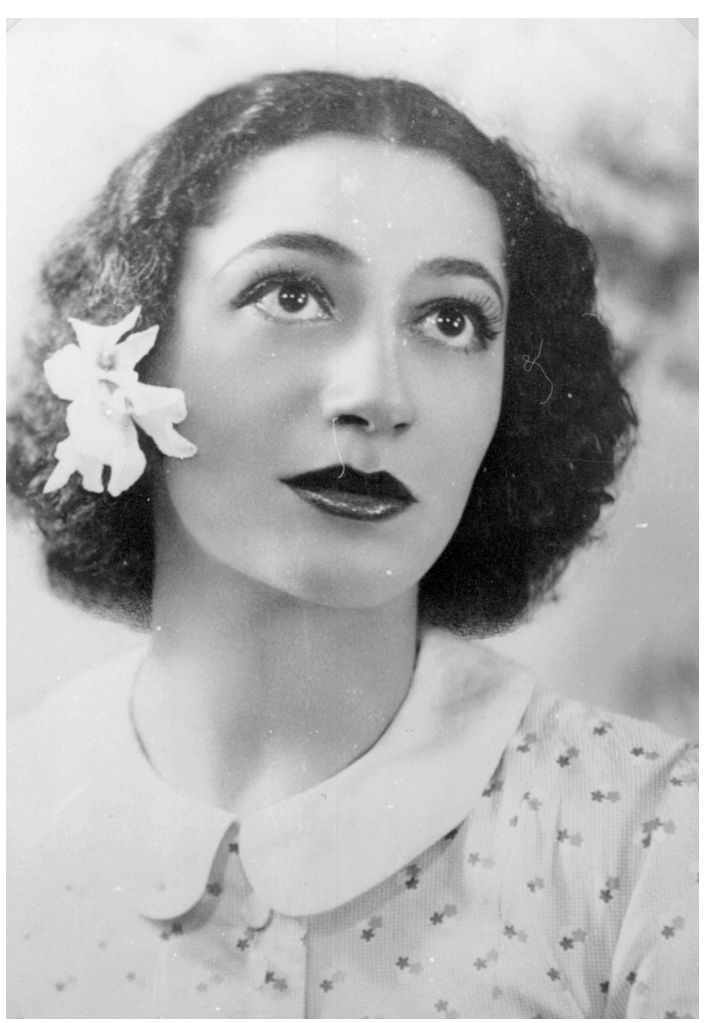

Fig. 3. Ramai Te Miha. c.1940. PH300. TAM

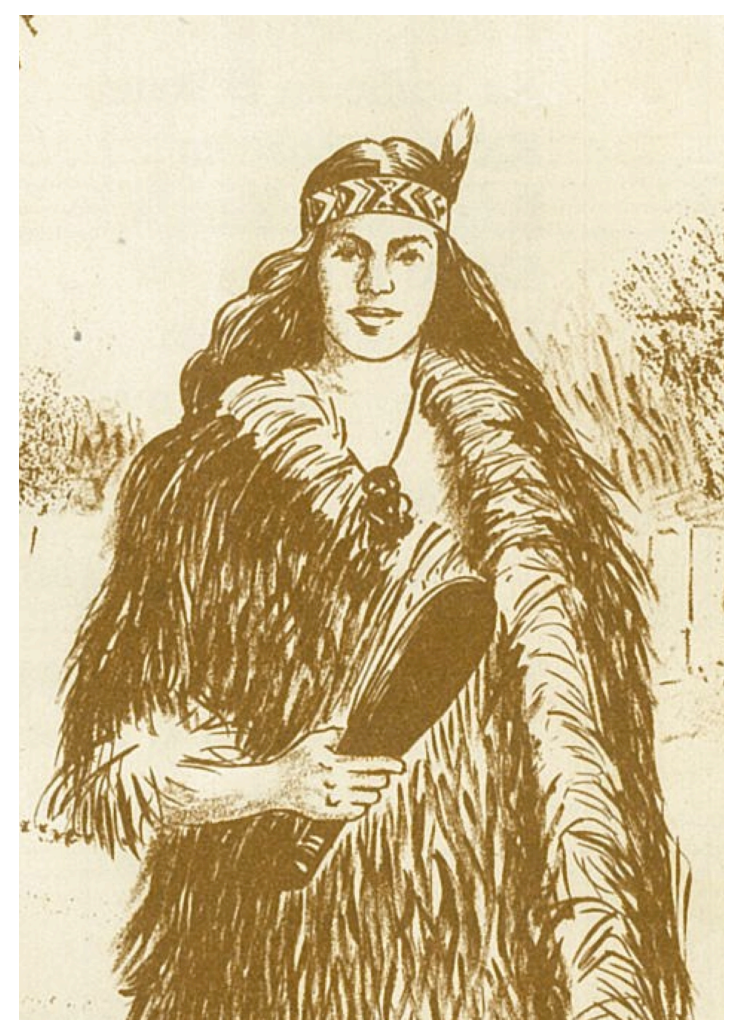

Fig. 4. Home, Little Maori, Home. 1939. Charles Begg and Co. (detail) 
In both publicity photographs above Te Miha averts her gaze in a submissive 'gendered stylization of the body' (Butler 1999, xv). Belich (2001, 491-492) identifies the 1930s as the period when films, radio, and women's magazines all began to emphasise idealised romantic marriage as the norm and a woman's place as the home in a 'cult of domesticity'. In the Hollywood woman's film the submissive feminine stereotype is reinforced by music that 'speaks for' women made physically, psychologically or selectively mute (Laing 2007, 28). In Rewi Hill uses orchestral arrangements of 'Home, Little Maori, Home' as a cinematic code, a musical motif that ostensibly 'speaks for' Ariana describing her subjectivity, but underneath reveals Pākehā desires. As Russell Campbell $(1986,14)$ notes, 'In moments of lyricism and passion, the pakeha [sic] hero is united with the dusky maiden of his dreams...the hero's erotic attraction to a Maori woman is suggestive of his attachment to New Zealand; the love she returns is the ultimate vindication of the pakeha presence'.

The motif is first heard in lush strings and harp as Ariana and Robert share an intimate moment in the forest. Next a discordant distortion of the motif in the last bars of the cue 'Taiaha Fight' describes Ariana's fear of her loss of a future home with Robert as she mutely watches him knocked unconscious to the ground at the hands of Tama Te Heuheu. After being pursued by Maniapoto warriors, Robert and Ariana hide among the trees (once more), and as Robert mentions his plan to take Ariana to Auckland the motif begins in its romantic form, swelling to a climax as they kiss. Later the strings play the motif in an ominous slowly descent featuring ponticello and tremolo as Ariana, wounded escaping from Ōrākau Pā, stoically and silently limps along undercover of a stream's bank. Finally the motif reappears in its original romantic form as Ariana lies mute in her weakened state, watched over by Robert and her father. Each time the Pākehā home future is threatened, Ariana's anxiety is represented by a distorted motif; each time it is within her grasp, her joy is expressed by the motif played in its full romantic form. While Hayward's narrative constructs a racially conflicted Ariana who 'chooses' her Māori identity, Hill's motif appears to 'speak' her overwhelming desire to change. 
'Home, Little Maori, Home' also works in Rewi as a cultural code of colonial patriarchy that supports Ariana's construction as a Maoriland maiden awaiting civilisation. The fantasy of her Native womanhood is broken down into representations of her as, on one hand, an innocent child of the Māori home past and on the other the mother of the home future. Ariana is portrayed as a child in her use of broken English, despite her long association with the Morgans and her mission education. This narrative of childishness innocence is supported by Hill's (or possibly Hayward's) decision to use 'Home, Little Maori, Home', which recalls the lullaby theme of modern waiata. Hill plays on this connotation in particular by using the lilting 3/4 refrain of the song repeatedly to suggest the security of the Pākehā home future.

The lullaby theme also represents more directly Ariana's heteronormative sexuality and potential maternity. During the village scene, and directly preceded by a Maoriland image of a young smiling woman with a swaddled baby tied to her back, Ariana minds a group of children to Hill's arrangement of the lilting modern waiata 'Tahi nei Taru Kino'. Ariana's maternity is most clearly described, however, in a subplot now missing from the film in which she minds the boy Rimi while confined within Ōrākau Pā. For this subplot Hayward instructed Hill to insert a 'slumbersong' (Battle scene shooting script, AHMM, box 23), and at this point Hill wrote the cue 'Oriori Kua Ngenge Ariana', based on his newly composed Māori-themed lullaby (AHMM, box 35). Oriori are often described as lullabies but traditionally, 'their purpose was less to lull children to sleep than to educate them in matters appropriate to their descent' (McLean and Orbell 2004, 18). Oriori are sung to both boys and girls, have a simple uninterrupted melody, fast tempo, and additive rhythms (ibid., 1819). Hill's oriori songs do not demonstrate any musical features of Māori oriori, but in Rewi they mimic the oriori's nurturing function by subtly educating Ariana on her 'innate' suitability as the submissive partner of a racially harmonious home future.

To this point I have read Hill's music for Ariana as the sexualised and racialised trope of the Maoriland maiden, but, as in the song's historical life, it may also represent self-defined Māori identities; after all Māori too valued the 
lullaby theme of popular songs. Ballantyne and Burton $(2009,5)$ aim to re-define the imperial space of intimacy by arguing that studies of the cross-cultural sexual relations operating in localizing domains "anchor" white men into nonEuropean communities...[where] mobility becomes the property of the colonizers...the local, in turn, is rendered static and comes to represent the "primitive" cultures...' In this way, even in consensual relationships indigenous agency is 'rarely apprehended, let alone recognized as a subject of historical inquiry in its own right...' (ibid., 6). Ariana is indeed localised and objectified: fixed within the filmic medium; confined within a narrative that limits her to the mission station, her village, and Ōrākau Pā; and repeatedly called through music from a Māori home past to an integrated home future.

While acknowledging the pitfalls of potentiality essentialising 'native' response and imaging native agency only as response, Ballantyne and Burton argue for the consideration of how intimacy was embodied 'across the restless world of empires' (ibid., 7). They ask: 'How did bodies on the move both capture and elude the gaze of those in charge of policing them?' (ibid., 8). I see a parallel between their discussion of the mobility of bodies within the gaze in the history of colonial intimacy, and the mobility of bodies within the gaze who re-tell intimate colonial histories. What if Ariana could move? Without producing a revisionist re-make of the film, she must remain in the Waikato and within a Pākehā narrative, but what if she was to escape the screen altogether and in doing so escape her Pākehā-defined homes? The music of melodrama not only speaks for the muted woman to teach her how to behave under patriarchy but also 'expresses that which cannot (yet) be said' (Byars 1991, 13). If Ariana could move, what unspoken prescience might we hear in Hill's music for her?

Annabel Cooper $(2013,163-164)$ has shown that accounts of interracial 'natural affections' described within Pākehā texts of the New Zealand Wars, including Rewi, do not only uphold colonial authority but are sometimes based on historical events and the lived experiences of their narrators. Hayward (c.1961) remembers as his inspiration for Ariana Pākehā accounts of an attractive 'half caste' girl named Horiana present at the battle of Ōrākau. She survived the siege under the protection of a British soldier but when, at her 
request, the two were later reunited the couple became shy and embarrassed. Hill's alternately discordant and harmonious motif for Ariana conjures not only racially filtered fears of an unstable nation, but, on the personal level of intimate 'natural affections', may represent cultural memories of personal anxieties and joys inherent in historical interracial relationships.

Through Te Miha's powerful position as the film's singing star Hill's fluctuating motif may also have brought to mind the conflicting emotions inherent in 1930s lived experiences of interracial relationships. Te Miha was born in the Wairarapa to Roihi Te Miha and Irishman Fred Mawhinney, but after her father died in World War One her mother remarried and Te Miha became known as Patricia Miller (Amoamo 1993, 234). As a child her Māori identity was suppressed and nurtured; while at school she was beaten for speaking Māori (Ramai Hayward, 1996), at home she was surrounded by large portrait photographs of tupuna (ancestors) (Amoamo 1993, 234). In 1929 Te Miha moved to Christchurch where she was inspired by art and drama classes at New Brighton School, afterwards studying photography in Wellington under Henri Harrison before moving to the North Shore, Auckland, in 1937 to open her own business, the Patricia Miller Studio (ibid.).

Richard Dyer has identified three concepts of the star image: it is made of media texts such as publicity, films, and criticisms; it has a 'structured polysemy' that enables multiple interpretations; and stars embody ideological contradiction through which social conflicts and crises are negotiated and resolved at the symbolic level (Shingler 2012, 20-23). Through the media Te Miha was established as Māori film star in the Hollywood mould. Hayward promoted her specifically (and erroneously) as 'the first Māori screen star' ('Music and Melodies', Auckland Star, 11 April 1940, 9), and on 5 November 1938 the Auckland Star reported that American baritone Lawrence Tibbett had 'prophesied world recognition' for her voice. Previews describe Te Miha's singing as a feature of the film, she herself is referred to on more than one occasion as a 'famous Maori singer' (for example Auckland Star, 26 February 1940), and while the film was still in its first run she sang 'Home, Little Maori, Home' on 1YA ('Broadcasting', Evening Post, 19 June 1940, 5). 
Hayward's promotion of Te Miha as a Māori singing star was reinforced by her own ethnic delineation at this time. As Deborah Shepard $(2005,118)$ observes, she varied her name to undergo 'chameleon-like changes of identity to fit the current political climate'. A promotional bridal self-portrait of Te Miha from this period (reproduced in Amoamo 1993, 235) demonstrates her photographic skill and business acumen, raising the possibility that she herself designed the pair of 'chameleon-like' publicity photographs above, as she did the film's publicity posters. Te Miha ran her photography business as Patricia Miller, but when she won the part of Ariana she adopted her mother's family name (Shepard 2005, 118). Kaihau, from whom Te Miha received singing lessons in preparation for her role (Te Awamutu Courier, 4 February 1938, 2), made a 'profound' impression on her and perhaps contributed to her Māori identity:

[Kaihau] was an exceptional person. Exceedingly attractive, with a dynamic personality - utterly feminine and not without the exasperations which accompany femininity...she was very gifted and her playing of her own music would have been a contribution towards our Maori culture. (Te Miha quoted in Annabell 1975, 253)

Te Miha may have also been influenced by the film's tragic historical narrative, recalling, 'I got emotionally involved, it was reliving an important part of the Maori people's past' (Horton 1973, 43). Te Miha's own ethnic connection with Ariana's character was reflected in that of her audience. Several people told her over the years that they had named their daughter Ariana (Ramai Hayward 1985). Through the conflation of the character of Ariana and the singing star persona of Te Miha, those Māori women audience members in their own interracial relationships with Pākehā men may have felt an affinity with Ariana's reluctance to deny her Māori identity.

In 1943 Te Miha married Hayward. In joining forces with him in his filmmaking career, she changed her preferred name once again. By considering how the intimate body of Horiana/Ariana/Te Miha/Ramai Hayward moves through time, and between fiction and reality, we can appreciate how Ariana negotiates the colonial gaze. Hill's melodramatic 'Māori' lullabies, and in particular 'Home, Little Maori, Home', 'speak for' her, expressing what Hayward's 1864 narrative and 1930s society can and cannot (yet) describe. 
Through the polysemy of her position as a Māori singing star Te Miha represents the fantasy of the Maoriland maiden and Māori women negotiating Māori history and the Māori home present.

\section{Conclusion}

Ariana's ambiguous identities are reflected in her ultimate fate, at times interpreted as the non-white heroine suffering an inevitably tragic end (Blythe 1994, 47; Fox 2011, 61; Cooper 2013, 164), a position supported by the title of Hill's final cue 'Death of Ariana', or surviving to create the narrative closure necessary to symbolise a racially harmonious New Zealand (Hayward and Reed 1944, 145-149; Campbell 1986, 6). It is, however, this very uncertainty that is the crux of the matter. As Ramai Hayward explained in 1972, '...you know she [Ariana] did not really die. The film left you to work out what happened yourself ('In City For Opening of NZ Film', Gisborne Herald, 5 October, 7). Ariana's uncertain fate accurately reflects the work required to reconcile the contradictions in 1930s New Zealand society between interracial intimacy and racial prejudice, and between lived experiences and ideological biculturalism.

'Home, Little Maori, Home' achieved Hill's twin desires to uphold Māori culture and create a Pākehā sense of nationhood, although perhaps not in the ways he had imagined. Through Maoriland imaginings Pākehā called Hill's 'little Maori' to a Māori home past, settlers' homes past and present, and over time to a New Zealand home future. For some Māori, however, this song seems to have represented self-defined ethnicity and imagined communities of gender, iwi, nation, and Empire. In Rewi 'Home, Little Maori, Home' signified both nationalist ideology and recalled real anxieties and joys of interracial 'natural affections' anxieties and joys that had perhaps been the inspiration for the song's composition in the first place. Up until 1940 when the song came to represent a Maniapoto woman of Waikato it was associated with Te Arawa of Rotorua and Ngāti Raukawa of Ōtaki. This change in itself is a significant hegemonic force in support of Hayward's theme of a racially harmonious nation. 


\section{Chapter Five}

Civilising the Frontier: 'Song of the Locust'.

The story of the last day in Orakau imperishably remains as an inspiration to deeds of courage and fortitude. Nowhere in history did the spirit of pure patriotism blaze up more brightly than in that little earthwork redoubt, torn by gun-fire and strewn with dead and dying. The records of our land are rich in episodes of gallant resistance to overwhelming force, but they hold no parallel to Orakau. Suffering the tortures of thirst, half-blinded with dust and powder-smoke, many bleeding from wounds which there was no time to stanch, ringed by a blaze of rifle-fire, with big-gun shells and grenades exploding among them, the grim band of heroes held their crumbling fort till this hour against six times their number of well-armed, well-fed foes. Now they must retreat, but they would go as free men. (Cowan 1983, 1:395)

The extant version of Rewi cannot give us an accurate sense of the extent of the horror and romanticisation present in Hayward's original portrayal of the closing hours of the battle of Ōrākau, however a study of Hill's cues based on the haka 'Song of the Locust' can help us appreciate just how strongly Hayward desired to confirm the nation through the civilising myth of Ōrākau and how closely Hill supported him in this.

This chapter begins by briefly situating Hill's interest in this song within the broader context of Pākehā interest in Māori music up until the early twentieth century, and then considers more specifically the ethnographic context of the interracial 'knowledgeable group' (Ballantyne 2012, 187) who supported and encouraged Hill in his 'preservation' of Māori music. Next I argue that in his popular song and film cue arrangements of 'Song of the Locust', Hill initially emphasised primitivism through the influence of contemporary scientific theories of race and filmic conventions of the 'Indian' musical stereotype, before incrementally removing this to replace it with a stereotype that signified an ideal of western civilisation. Finally I consider the effectiveness of Hill and Hayward's Progress through Paradise in a discussion of this song's performance history since 1940. 
Henry Stowell, Haka, and Preserving Māori.

Little is known of the early history of Pākehā adaptation and performance of Māori music. The effect of Māori music such as waiata and haka on the first sealers, whalers, and traders has apparently not been the subject of detailed academic research. McLean (1996, 270) cites French navigator Duperrey's comments that sealers and whalers and Māori held a mutual dislike of each other's music, although Andersen (1978, 399-401) notes that Māori characters often featured in the lyrics of early sea 'chanteys'. Missionaries who began to arrive in New Zealand from 1814 deemed tattooing, singing, and in particular haka to be obscene and endeavored to prohibit these practices (McLean 1996, 270-272). This attitude may have discouraged, or censored evidence of, Pākehā appreciation and appropriation of Māori music. In what is an isolated case, perhaps due more to these factors and the ephemeral nature of nineteenthcentury music making rather than musical practice, the earliest formal Pākehā musical response to Māori music appears to be the song 'The Whalers of the Deep Deep Sea' (1857), W. Grandhan's piano arrangement of music by Te Heuheu (likely Te Heuheu III of Tūwharetoa) set to the words of Mrs St George (a pseudonym for Mrs Shayle George) (MacGibbon 2007, 93). Thomson (1991, 196) states that later in the century 'Māori melodies' were incorporated into Victorian ballads, but does not provide further details.

There is a clearer record of the intellectual response to Māori music by Pākehā, beginning with the journal entries of the European members of the voyages of Abel Janzoon Tasman (1642) and James Cook (1769, 1773-1774, 1777) (McLean 1996, 23). From 1840, settlers interested in history and ethnology began to study Māori music (Thomson 1991, 9-11, 14-15). George Grey collected song texts on observing that waiata often formed part of Māori argument in speeches and correspondence (McLean 1996, 113), producing Ko Nga Moteatea in 1853. The most common approach, however, was comparative, exemplified by James Davies' appendix to Grey’s Polynesian Mythology (1855) in which Davies favourably compared Māori and Greek musics, and seen more generally in the desire to consider Māori lyrics as poetry (Thomson 1991, 196). Thomson (ibid.) lists the main Māori song text collections dating from the mid to 
late nineteenth century: Edward Shorland's Traditions and Superstitions of the New Zealanders (1854); missionary Richard Taylor's Te Ika a Maui (1855); Charles Davies' Maori Mementos (1855); John McGregor's first volume of Popular Songs by the Waikato People (1864), collected from prisoners of war taken at the Waikato battle of Rangiriri; and John White's six volume Ancient History of the Maori (1887-1890), which included many karakia (ritual chants).

This collecting took on a new sense of urgency in the late nineteenth century as the Māori population declined. Percy Smith formed the Polynesian Society in 1892 with the aim of furthering the scholarly study of Māori and Polynesian cultures. He was one of an interracial group of intellectuals and artists including Āpirana Ngata, Peter Buck (Ngāti Mutunga), also known as Te Rangi Hīroa, Elson Best, Edward Tregear, Johannes Andersen, James McDonald, and Makereti Papakura who embraced the practice of salvage ethnography to preserve what remained of the culture of what was then thought of a dying race. These ethnologists were bicultural, usually learning the language, customs, and intentions of the other people, and are today known as cultural go-betweens or kaiwhakarite (Derby 2012a).

Like these ethnologists, most of whom he knew personally, Hill practised salvage ethnography, 'assiduously collecting and noting down the old music before it [passes] into the mists' (Press, 14 March 1908, 7). He observed that haka was 'rhythmically shouted', its syncopated rhythms 'filled in' with grimaces and slapping, and that the 'oldest' waiata melodies were unharmonised, often microtonal, limited to the range of a $4^{\text {th }}$, and through the leader's role, unbroken ('Maori Music a Tempting Field', Evening News (Sydney), 30 August 1913, 3). In keeping with the interracial makeup of these ethnologists, in 1906 Te Rangi Pai 'arranged about 30 Maori songs and ditties, her ambition being to preserve the sweeter songs of the native tongue' (Auckland Star, 15 May). This preservation of Māori songs was part of an international movement to save 'dying' races. In 1909 Australian composer Percy Grainger implored those he met during his New Zealand visit to fulfill their 'duty' to preserve Māori music (Barwell 2005, 5), and Charles Wakefield Cadman published Four American Indian Songs, based on 
Omaha and Iroquois melodies collected by Alice Fletcher and Theodore Baker, respectively.

Hill was likely most strongly influenced in his ethnographic practice, however, by James Cowan. At a recent symposium held at the National Library, 'Cultural Go-between, Colonial Man', Cowan too has been recognised as a cultural go-between. As described in Chapter Three, he had a bicultural upbringing and published extensively on the subjects of Māori culture and New Zealand history. Paul Meredith (2014) argues that while Cowan's writing often shows the influence of Pākehā romanticism, his practice differs from other ethnographers of the time in his use and attribution of Māori informants. Chris Hilliard (2014) suggests Cowan's unusual method for the time of privileging Māori oral history histories over Pākehā accounts in his New Zealand Wars was his way of honouring Māori and is a reflection of his emotional investment in his work.

Cowan and Hill had a collegial relationship during Hill's early intensive period of contact with Māori. Hill remembered Cowan as 'more of a Maori than a white man', and recalled that it was through Cowan that he met Henry Stowell (Hill 1958, T1935). ${ }^{32}$ For his part, as noted in Chapter Two, Cowan included examples of Hill's collected material in his 1907 tourist guidebook New Zealand and likely also in his official record of the 1906-1907 Christchurch International Exhibition where he noted that Hill had made 'the interpretation of the special spirit and genius of Maori music one of his particular studies' (1910, 376). Most revealing, in a 1919 letter to Hill Cowan expressed a desire to correspond on the subject of their '...mutual Maori waiata interests' (AHPP, box 2, emphasis in the original). Hill never became a fluent speaker of Māori; nevertheless he developed relationships with particular iwi, was emotionally invested in his work, usually attributed his sources, and can be considered to have recorded and disseminated musical histories. In the context of the early 1900s, I argue Hill too was a cultural go-between.

32 Cowan's second wife, Eileen, was Stowell's daughter. 
The desire of ethnologists to preserve Māori culture was aided and perhaps partly driven by the advent of recording technology. Late in life Hill recalled that in the 1890s he was 'responsible' for a collecting trip in the Urewera by McDonald and Cowan during which 200 wax cylinder recordings were made (New Zealand Herald, 19 June 1952, 1), later identifying the location as the King Country (Thomson 1980, 189). Although it is probable that the first recordings of Māori songs were made in the 1890s, Hill's role in these has been debated (Thomson 1980, 189; 1991, 203; McLean and Curnow 1992, 14-16). Certainly Alfred Knocks of Ōtaki, husband of a Māori woman, recorded Māori songs on or prior to the date he recorded songs of the Rarotongan party who had recently visited the 1906-1907 Christchurch International Exhibition; in 1909 he gave copies of some of these to Grainger who himself soon afterwards recorded Māori songs at New Plymouth (Barwell 2005, 4-8).33 The same year C.A. Young, who had been in contact with Knocks, wrote to Grainger of his intention to make a government-aided collecting trip to a remote area (ibid., 10). By this year, however, Ngata already held at Gisborne his own collection of recorded Māori songs (ibid.,4), suggesting the extent of pre-1907 recordings now lost.

From 1919 Best, Andersen, and McDonald, on occasion assisted by Buck, Ngata, and Henare Balneavis (Ngāi Tāmanuhiri; Te Whakatōhea), made recordings during three government expeditions to Gisborne (1919), Rotorua (1921), and Whanganui (1923) (see McLean and Curnow 1992, 5-13). ${ }^{34}$ Five months after the first expedition on 29 September Henry Stowell recorded at an unknown location the haka 'Song of the Locust' (Hongi, 1919; McLean and Curnow 1992, 53). Stowell too was a cultural go-between, 'one of many nineteenth-century New Zealanders who were genuinely bicultural and who moved easily between and within Maori and Pakeha communities' (Gibbons 2014). Also known as Hare Hongi, he was born at Waimate North in 1859 to an American father and Māori mother, and attended the Wesleyan Native Institution at Three Kings in Auckland before studying with tohunga (cultural

\footnotetext{
33 Grainger's recordings of Māori song are apparently the earliest surviving.

34 Marcelle D'Oreen (Doreen Walsh) reportedly set poetry by Johannes Andersen and Jessie Mackay to the music of these government recordings ('Maori Song Cycle', Evening Post, 20 October 1921, 3), however Andersen later $(1934,410)$ discounted Walsh's use of this music in relation to his own words.
} 
expert) Nga Kuku Mumu at Waitaha, from whom he acquired an enduring interest in Māori mythology, genealogy and cosmology (ibid.). Stowell later lived in Wellington, worked as an Interpreter for the Native Affairs Department from 1908 to 1921, gave public lectures on Māori lore, and tutored private Māori language students (ibid.). He also played the violin and credited himself for adapting 'Hoki Hoki Tonu Mai' to an upbeat poi song with the tune of 'Little Brown Jug' (HMSP, folder 4).

Stowell embraced Pākehā culture but was skeptical of the prevailing Pākehā romanticisation of Māori lore and legend, in particular Percy Smith's invention of the Great Fleet (HMSP, folder 1). ${ }^{35}$ Although his tohunga forbade him to record sacred knowledge, Stowell often took the opportunity to rebut many Pākehā scholars' interpretations of Māori legends-as-history in The Journal of the Polynesian Society and newspapers (Gibbons 2014). He also collected, translated, and annotated in great detail many waiata (HMSP, folders 26 and 38). Stowell was concerned with the correct performance practice of what he considered to be Māori songs. For example, during 1932 he sent to Wellington carillonist Gladys Watkins 'Māori ballads', descriptions of Māori singing technique, and critiques of her performance (HMSP, folder 9). Despite his tohunga's restrictions, Stowell clearly desired to educate Pākehā through the dissemination of what he regarded as correct cultural information.

It is perhaps Stowell's desire for greater bicultural understanding that led him to record the haka, 'Song of the Locust, a Maori Posture Song and Dance' for government ethnologists. ${ }^{36}$ Haka song is characterised by recited, stylised shouting, compound metres, occasional additive rhythms that sound as syncopation against regular takahi (stamping), and the slowest tempo of all the recited styles (McLean and Orbell 2004, 21). Stowell's recitation is divided into three sections: the first in 9/8 has a downbeat rhythm and brief rest after the ultimate 'hoki mai'; the second in 6/8 has syncopated rhythms, a straight rhythm on the words 'we-he-ru-a ta-nga o te po', and a whakaū on the word 'po'; and the

35 In 1934 Andersen $(1978,376)$ described Smith's practice as the 'modernizing touch of a Percy', while Belich $(1996,24)$ calls it 'Smithing'.

36 The insect 'tarakihi' or 'kihikihi' is the cicada, sometimes colloquially known as the locust. 
third in 6/8 has syncopated rhythms and a whakaū on the ultimate 'Ha!'. There is no audible takahi or pākia (slap). The tonal centre of the largely monotonous melody shifts within a semitone in the octave below middle $\mathrm{C}$ once over the course of the recitation from around E-flat down to D and back up to E-flat as Stowell's tempo increases. ${ }^{37}$ His final whakaū on 'Ha!' drops from E-flat to C. ${ }^{38}$

Stowell also distributed English translations of 'Song of the Locust' to several individuals, including Hill (HMSP, folders 25, 38; AHPP, box 16). The three sections have varying subtitles: the first, 'Solo', 'Kai-taki', or 'Leader'; the second, 'The Song', 'Umere' (cheer or applaud), or 'Chorus'; and the third, 'Kia Kori', 'Get Active', or 'Chorus and Locust Song'. These slight variations, and those in the performance directions and the English lyrics of Stowell's copies suggest he distributed them over a period of time. His translation of the second and third sections below are taken from the copy held in Hill's papers:

The Song

E, whakarongo ai au

Ki te tangi mai

A te Manu nei

A te Tarakihi

I te weheruatanga o te po

Chorus and Locust Song

Tara-ra-ta ki-ta ki-ta

[cicada call]

Tara-ra-ta ki-ta ki-ta

Wiri o papa to-wene to-

wene

Wiri o papa to-wene to-

wene

Hope whai ake!

Turi whatiia!

Ei Ei Ha [exclamations]
0 , listening as once I did

To the breezy song

Of this bird of birds

Of the Tarakihi (Locust)

In the mid-division of the night.

Tara-ra-ta ki-ta ki-ta

Tara-ra-ta ki-ta ki-ta

$\mathrm{O}$ quivering sides sound your refrain

0 quivering sides rustle and cling-to

Upward moving waist

And so busy knees

Ei Ei Ha
[Actions]

[Keep thigh slapping, foot stamping, and extending and withdrawing arms as in

the introductory section]

One clap of hands. Quiver them and turn from side to side [repeat]

Slap waist once, keep hands quivering always Slap knee Place one arm across chest, the other erect beside the head

\footnotetext{
37 In comparing Stowell's recitation to other contemporary wax cylinder recordings it seems his pitch and tempo variation are part of his performance rather than the result of the mechanism winding down.

${ }^{38}$ Hill (1952a) recalled that on an occasion when he perceived Stowell to perform a melody 'all sung on one note', Stowell replied that he had actually ranged over 'an octave'. Hill was keen to establish whether Māori used microtonal modes, but Stowell may have been expressing metaphorically the breadth of range he himself could distinguish in the song.
} 
Andersen $(1978,382)$ notes in his analysis of this haka, for which he too used Stowell as an informant, that the syncopation of the third section, in which the first beat of the metre is left empty of words, is characteristic of Māori rhythms, and that 'the Maori poet has secured one of the many rhythms of the cicada'. Elsewhere he notes that the cicada's call is the 'bird song' prized above all others by Māori (Andersen 1923, 765). Andersen $(1978,372)$ explains the significance of the words of Māori songs: '...every song had its point; its definite object. With a song an orator would drive home an argument [...] each one was then a culminating point; a telling allusion; a flash of revelation'. In 'Song of the Locust', the rhythmic call of the cicada alludes to the division between night and day and symbolises the transformation of 'flying onto higher things and beings' (Max Cryer authorised by Henare Te Ua, pers. comm. 10 April, 2014). Stowell noted that although his English translation corresponded to the Māori words, 'it by no means gives the native spirit, or, thrill, of the original' (HMSP, folder 25). However in all versions he asks the performer to 'note the perfection of the rhythm and the peculiar treatment of the strong beat of the bar'. Stowell may have felt that the correct performance of the cicada rhythm would compensate somewhat for the unavoidable inadequacy of the English translation in transmitting to the audience the song's cultural allusion.

Hill collected 'Song of the Locust' from Stowell and arranged it for voice and piano on an unknown date, and published it in Songs of the Maori (1926, 1213). In his eighties he stated that the haka was a 'very old song' that he had arranged exactly as Stowell had given it to him, 'tune and all' (1952a). However, the diatonic wide-ranging melody characteristic of European song and modern waiata suggests the tune was a recent development. Stowell's almost monotonous recitation, Hill's composer's note inviting the performer to sing his arrangement, 'as printed, or rhythmically shouted as the Maoris do it' (emphasis added), and his application of a melody to another haka, the Tūwharetoa 'He Haka Ngeri' (AHMM, box 35), taken together suggest to me that it was Hill who added the melody. ${ }^{39}$ Hill also added $\mathrm{C}$ minor harmony, perhaps influenced by Stowell's ultimate melodic interval, and changed the compound metre to an

${ }^{39}$ Hill's transcription of Stowell's recitation and his manuscript arrangement are not held in his papers at ML. 
allegro 3/4, perhaps wishing to avoid connotations of European dance idioms and pastoral themes (for example Hill's film cue 'Forest Scene' is in 6/8).

What we may not appreciate from Hill's version alone is the extent to which he retained features of Stowell's recitation and transcription, although he does acknowledge Stowell's importance as an informer and interpreter in the collection's front pages. Hill used Stowell's title, through-composed three-part form, rhythms, syllabic word setting, explanation of the importance of the syncopation, and like Stowell, privileged the Māori lyrics by placing italicised English lyrics beneath them. As in 'Waiata Poi' and 'Home, Little Maori, Home' he kept the most important lyrics, here the cicada's name and call, in the Māori language within the English lyrics. The 3/4 metre he adopted resulted in irregular three-bar phrases in the introduction, which he valued, ${ }^{40}$ and despite his apparent melodic invention, as noted above Hill also valued Stowell's performance style of 'rhythmic shouting'.

Stowell may have influenced Hill's view of Māori rhythm. He (17 October 1923, HMSP, folder 9) once explained to Gladys Watkins that 'Maori melody is rhythm, rhythm'. For Stowell the melody of Māori music is defined not by consecutive pitch relations but by consecutive, irregular pitch durations and accents. Mrs Roberts, a correspondent of Andersen's, also recognised the 'nonmelodic' quality of Māori melody: 'I sometimes wonder if the points we do not reproduce exactly in attempting to imitate primitive or any exotic music are not more those of tone-quality, attack and release, glides, etc., than actual pitch...' (Roberts quoted in Andersen 1978, 440). While Roberts discusses 'primitive' musics, Stowell's comments to Watkins, who is playing Māori songs in the European idiom of Stowell's own choosing, imply that the aesthetic of this cultural characteristic should inform her performance. Hill's retention of the characteristics of Stowell's recitation suggests that within the confines of popularising Māori music, he aimed to preserve Māori musical values.

${ }^{40}$ Hill admonished McKinlay for lengthening this phrase to four bars (McKinlay c.1928; Hill 1952a), and McKinlay apparently apologised (McKinlay 192-, AHPP, box 3). 
$\underline{\text { Rewi's Last Stand: 'War-like sounds' of Musical Conversion }}$

Hill was respectful of his Māori sources and appreciated the unique characteristics of Māori music and language, but his values and beliefs were also informed by contemporary racialised ideologies. The Timaru Herald of 4 October 1913 reported 'In Mr Hill's view, the Haka [sic] and war dance, with their wonderful rhythmical shoutings and expressive gestures, gave a vivid idea of the emotion at the back of a storm'. In reply to the enquiry as to how Māori could represent a storm with the limited melodic range of pre-European Māori music, Hill referred the interviewer to the repetitive Ds in Wagner's Die Walküre, 'Why, this is the same glorious monotony that I have heard in the Maori war songs'. His comparison of haka and 'serious' nineteenth-century German music with its strong associations of nationalism hints at his desire to ennoble Māori in the name of the nation. ${ }^{41}$ Continuing, Hill clarifies that he considers rhythm the most important element of haka, and indicates that for him haka is central to Pākehā identity:

If it were only for the rhythms, Maori would still have something to add to our modern music. Every Maorilander knows (or ought to know) the wellknown 'Kamate Ka mate' [sic], and its vigorous rhythms. Many of us have heard the 'Haul up the Canoe', and where have we met with rhythm to better this? What accents! What a swing! How it sways and surges, like the roll of a great and proud war canoe. (emphasis added)

Hill's theory of the evolution of Māori music, recorded during an interview with Ashley Heenan in 1952, shows how he also linked indigenous rhythm with primitivism:

...first of all, we get to the Maoris rhythmic shouting. Well then, I always thought that there might be a stage follow[ing] that, like these very old chants, laments, and even love songs that did use smaller intervals. Then there was another stage in which the range was a little more extended and these songs could be taken down with our system of notation. (Hill 1952a)

Hill's employs both Black and White Maori stereotypes to describe how haka can at once represent the nation's authentic origins through 'primitive' rhythm and indigenous civility on a par with that of the European through rhythmic melody. Although his comments here span forty years, Heenan's own comments in the

41 Grainger also compared Māori music favourably to Wagner's (see Barwell 2005, 7). 
1952 interview on the evolutionary theory of 'primitive' musics mirror Hill's exactly and show that the influence of indigenous rhythm in Maoriland imaginings is an enduring one. Indeed, for many Pākehā today the haka 'Ka Mate' remains a corner stone of national identity. Within this racialised nationalist discourse surrounding haka the Māori cultural allusion to transformation heard in 'Song of the Locust' is translated for Pākehā into potential for the racial other's Progress and entry to New Zealand.

In his popular song adaptation of 'Song of the Locust', I argue that Hill unconsciously turned to a stereotype of primitive melody that accentuated rhythm. Rhythm had long been employed as a rhetorical device for otherness in European music, but Michael Pisani (2005, 85-86) argues Henry Bishop's 'Yes, 'tis the Indian Drum' from Cortez (1823) marks a paradigm shift to a 'more indexical lexicon of "Indianism" that took hold in the early nineteenth century'. This 'war-like sound' is characterised by dotted rhythms, the regimental character of an English military march, the 'simple yet ominous effect' of a reiterated note broken by quick alternate hopping of a fourth or fifth, and pulsing, drumbeat-simulating chords in the often minor mode accompaniment (ibid., 86, 118). A further 'conspicuous semantic device' is a pattern of three descending semiquavers of scale degrees $5,4,3$ or $3,2,1$, the first note always accented and the motif highlighted through repetition. Pisani says that along with Alla Turca grace notes these devices made up a '...virtual tool box of signifiers to connate savagery and paganism [that] emerged with startling clarity in American sources by the 1850s' (ibid., 122).

Hill employs some of these 'war-like' devices in his popular song arrangement, particularly in the introduction (example 1 below). An ominous mood is set by his minor mode and repetitive harmonically static phrases. But musical Indianism is most obvious in the melodic line that descends through scale degrees 5 to 1 incorporating repetition of figures that descend through scale degrees 4, 3, 2 and 3,2,1, the downbeat in each case further emphasised with an accent. Although some of these figures include quavers, the triple time meter retains the three-note effect. This device is particularly emphasised within the secondary dominant harmony of the final phrase. At the mention of the 
cicada's 'breezy song' the descending three-note figure is incorporated into Stowell's syncopated rhythm (example 2 below). However on the word 'tarakihi' the melody quietly 'takes off' and undulates over static harmony in flowing crotchets, losing any connotations of Indianism and in alluding to the cicada's flight rather than its call, any Māori ones too.

Ex. 1. 'Song of the Locust', bb.1-13.
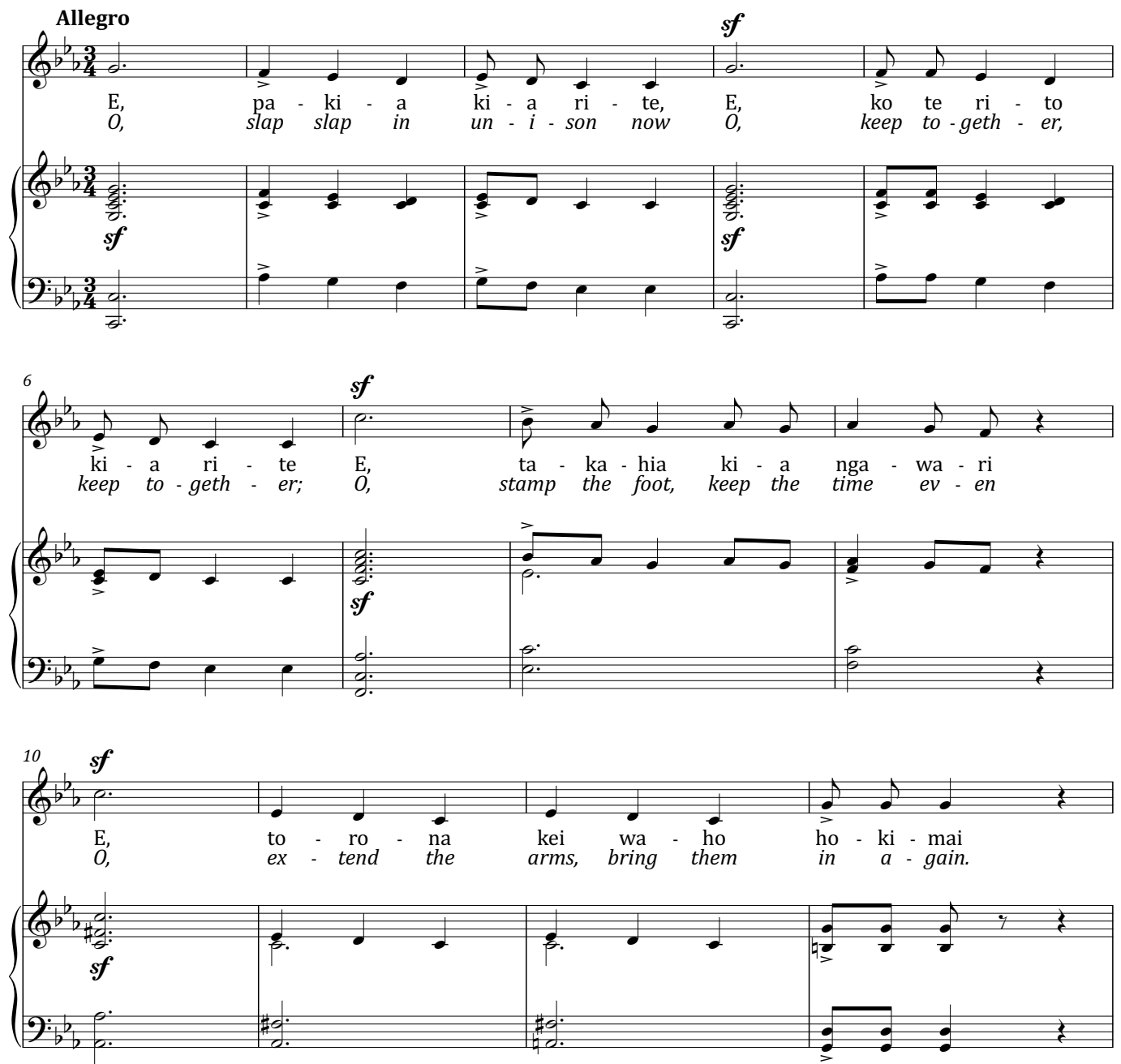

Ex. 2. 'Song of the Locust', bb.17-20.

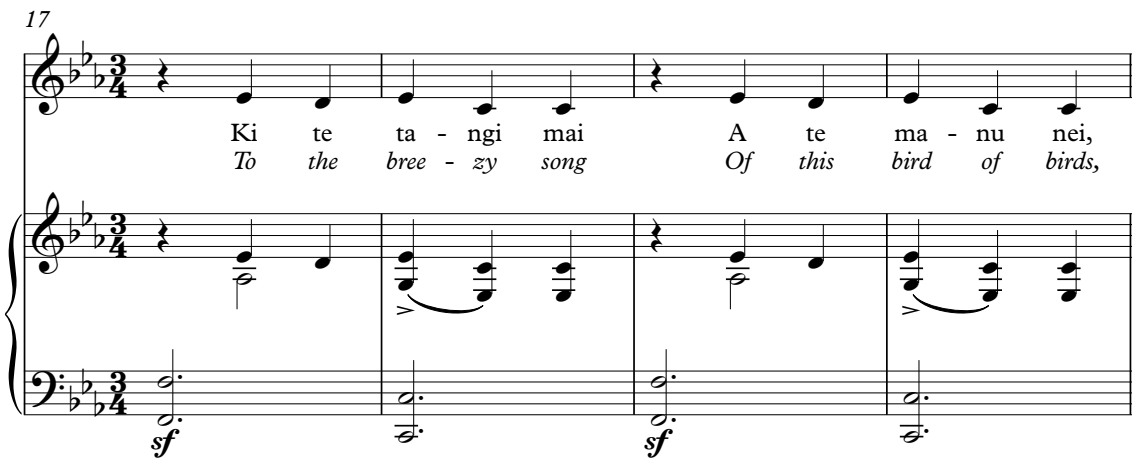


As in Stowell's transcription, the syncopated, monotonous call of the tarakihi begins the third section (example 3 below), however rather than stand out as the focus of the song, the accompanying dominant harmony suspends time as we await the return of the opening melody in the second part of the third section, by which Hill splits this last section in two and creates a melodically rounded form. On the final words 'Hope whai ake! Turi whatiia' he introduces the device of a reiterated note broken by descending hopping fifths, an interval which in retrospect cements the repetitive descending five-note outline of the opening phrases.

Ex. 3. 'Song of the Locust', bb.27-30.

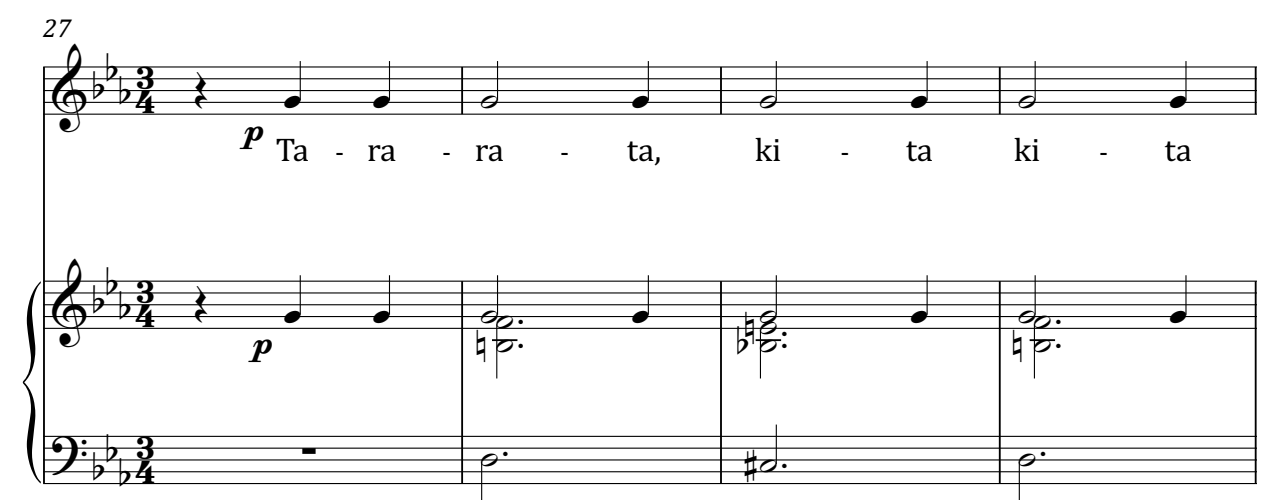

The triple metre and a piano accompaniment that largely doubles the vocal line limits the song's potential as a percussive march. In Rewi, however, Hill put the Indian drum device to work. John Ford's Stagecoach (1939) was released the year before Rewi, and 'Perhaps more than any other film, [it] cemented in the public's mind what the classical Hollywood Western was all about - thrilling action sequences among breathtaking scenery of the Old West in which the white male hero defeated the Indians...' (Benshoff and Griffin 2009, 109). In Stagecoach 'Indian' drumming signaled the arrival of Native Americans before they appeared on screen (ibid., 108). When Stagecoach opened in Sydney in June 1939, the music was described as 'among the best brought to the screen...you'll hear all the famous Western songs and ballads running through the picture to add the right note and emphasise the drama...' ("Stagecoach" a Grand Thriller', Sydney Morning Herald, 19 June 1939, 7S).

Ford's film was unlikely to have directly influenced Hill, although it is possible. Hill had apparently finished writing the score for Rewi in early 1939 
(Frontier Films Ltd., 24 February 1939, AHPP, box 4), although the music remained to be recorded in mid June (Hayward 15 June 1939, AHPP, box 4). The next month Stagecoach opened in Auckland ('Amusements', Auckland Star, 14 July 1939, 16). By August 1939 Rewi was reportedly near completion ('Maori War Film', Auckland Star, 12 August, 1939, 7), however the first preview screening was not held until February 1940 ('Private Screening Held', Auckland Star, 26 February 1940, 3). Whether or not Ford's film in particular influenced Hill, by this time 'Indian' drums had become a cliché (Benshoff and Griffin 2009, 108), and advertising for Rewi such as 'Sway! to the rhythm of the war canoe chase' ('Amusements', Auckland Star, April 1940, 22) suggests this film shares the 'Indian' aesthetic of the Hollywood western.

'Song of the Locust' is heard first in Rewi during the waka chase scene as the cue, 'Canoe Pursuit'. Pākehā hero Robert is reunited with Ariana by the riverside on his return to the Waikato from Auckland with Governor Grey's warning that Māori who continue to 'remain in arms and wage war against Her Majesty must take the consequences of their acts'. The music begins quietly as Ariana warns Robert that he is in danger and they prepare to flee in a small dugout. Maniapoto men alerted to Robert's presence borrow a visiting war party's waka taua and give chase. The waka chase commences with quick cuts between the parties and close ups of the heavily tattooed face of Ariana's rival love interest Tama Te Heuheu as he urges his crew on from his position as waka leader. Hill's music for Rewi is largely made of repeated sections unsynchronised with the action, but here the music's beat matches the pursuers' paddle strokes. Robert and Ariana eventually evade their pursuers and the music fades as they find safety on the riverbank.

The 1940 audience would have been familiar with this song through domestic and public performances, McKinlay's c.1928 commercial recording for Columbia, and its probable use in primary schools as discussed in Chapter Two. However, the opening bars of 'Canoe Pursuit' instantly transform the lightly textured popular song into a menacing aural signifier. Retaining the minor mode, Hill emphasises the descending three-note figure of the introduction of the song with a rhythmically simplified three-note figure, contrasting articulation, and a 
low register (example 4 below). ${ }^{42}$ The most striking difference however is the introduction of an ominous drum motif. The percussive four bar introduction and the extra bar's rest at the end of each melodic phrase creates even four bar phrasing. This, with the single percussive pulse on the first beat of each bar, in turn creates a hypermeter over four bars and a slow march rhythm in keeping with Bishop's 'war-like sound'.

Ex. 4. Rewi's Last Stand. Cue 12: 'Canoe Pursuit', bb.1-8.

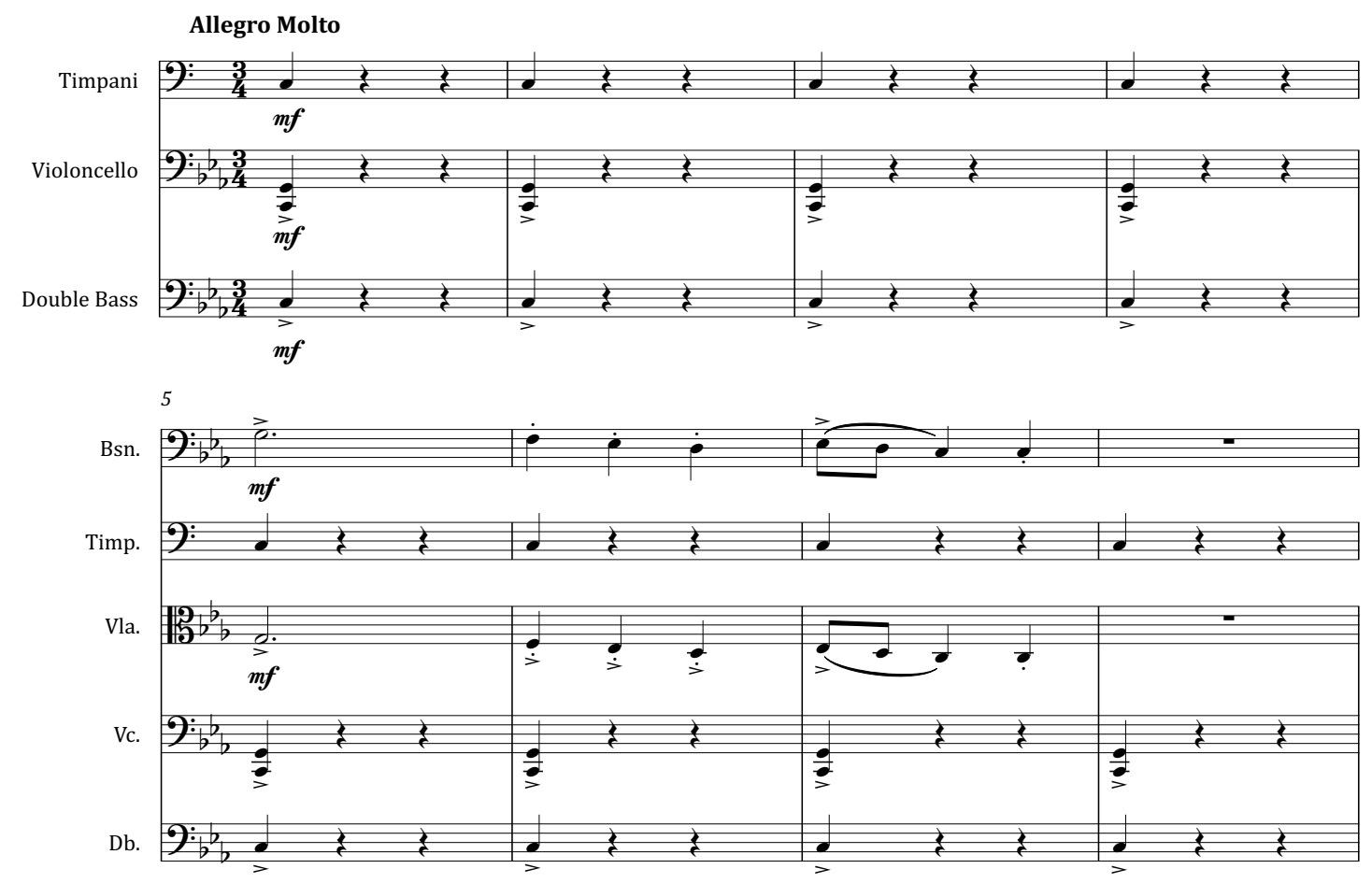

Hill then develops the second section of his song arrangement. He removes the melody, retains the syncopated rhythm in the higher instruments, and introduces in the lower instruments a figure that descends through a fifth as in the song's opening phrases but also through the effect of the syncopated accompaniment emphasises a three-note descent (strings extracted in example 5 below). This three-note figure is chromatic to allow for the section's part descent through a harmonic circle of fifths in long phrases. By retaining but obscuring the strong descending three-note figure from the song's opening, removing the haka's most significant cultural association of the cicada's call, and adding a percussive 'war-like sound' synchronised with a narrative of

42 All cues are reconstructed from manuscript orchestral parts (AHMM, box 23). Please also refer to the appended complete cue reconstructions. 
threatened violence against the white man, a non-martial posture song and dance alluding to transformation turns into a war song anticipating destruction, and Māori become the Indians of Hayward's western.

Ex. 5. Rewi's Last Stand. Cue 12: 'Canoe Pursuit'. 'Maniapoto' Motif, bb.30-41.
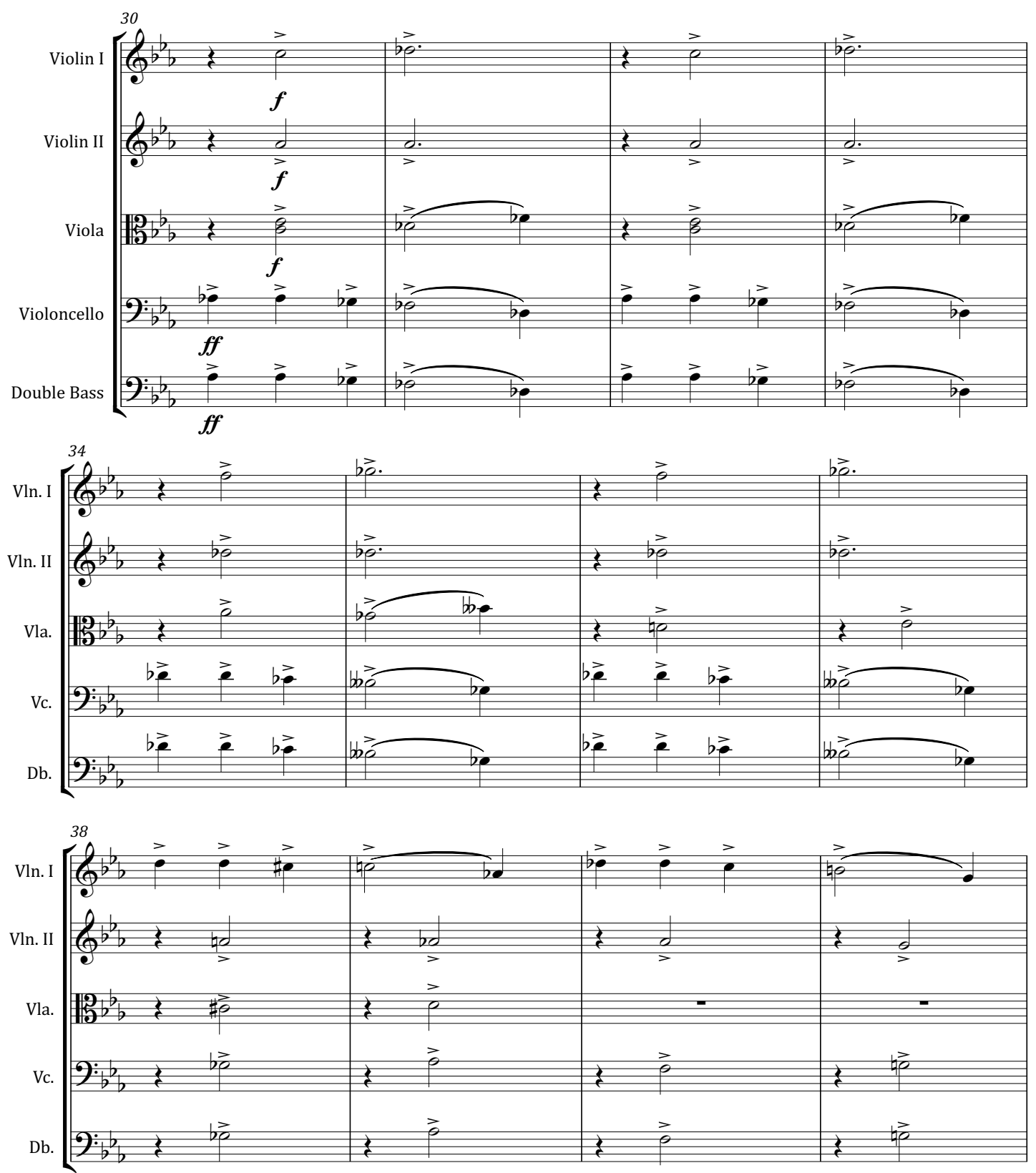

Hill uses 'The Song of the Locust' again soon afterwards during the scene 'Maoris Listen to Rewi on the Marae', where Rewi argues against engaging the Crown at Ōrākau. Like many other scenes concerning the historical narrative, this one demonstrates Hayward's romanticised desire for authenticity in the name of nationhood. The map of the greater Auckland area that opens this scene is reproduced directly from Cowan's New Zealand Wars (1983, 1:307), while 
Rewi's cautionary words on the marae are a condensed version of two prophecies of doom that he experienced prior to the battle of Ōrākau, as related by Cowan (ibid., 369): Rewi's description of himself as the lone koko (tui) singing at dawn, and his dream of a kite, which he flew outside Ōrākau church, falling to the ground and smashing to pieces.

Hayward also went to some lengths to recreate authentic settings, in one case travelling as far as the Urewera (Tūhoe territory) to film thatched houses (Hayward c.1971). The possibility that the thatched houses in the marae scene are those filmed in the Urewera highlights the fact that it was Tühoe who agitated for the defence of Ōrākau and made up the majority of the Māori force; most Maniapoto had already left the area (Cowan 1983, 1:370).43 In Hayward's marae scene, however, it is Rewi's own people who oppose him, one man proclaiming: '[unintelligible] is my home and I'll stand here at Ōrākau'. By striving for an authentic setting and generalising Māori representation Hayward creates the impression that only Maniapoto were present, bolstering the effect of Rewi's later words of heroic defiance and strengthening the myth of Ōrākau. Rewi's efforts to dissuade Māori from defending Ōrākau are unsuccessful and the scene closes as men perform a celebratory 'war haka' to a reprise of 'Canoe Pursuit'. This aural signifier, first heard as accompaniment to Maniapoto warriors chasing Ariana and Robert, now fixes in the minds of uninformed audience members the identity of the defenders of Ōrākau as a Maniapoto community.

Through Hill's 'war-like' music and Hayward's mise-en-scène of authenticity Maniapoto are established as Savages barred from modernity. To enter an idealised racially integrated 1860s/1940s New Zealand society they must be transformed and from this point forward in Rewi Hill manipulates the Maniapoto motif in the cues 'Haka of Defiance' and 'Maori Defiance' to civilise Maniapoto and create equal opposing forces. Originally the cue 'Haka of Defiance' (96 bars including repeat) segued from the cue 'Battle Music' (323 bars including repeat). In the extant film only the first fifty-six bars of 'Battle Music'

${ }^{43}$ Rewi had actually visited the Urewera the year before to raise support for Waikato Māori (Cowan 1983, 1:368). 
survives, the action cut short soon after the bugler's call to charge. A timed shooting script of the battle scene shows that from here the original battle shots have been re-ordered, and others have been eliminated, for example: shell bursts, falling soldiers and 'warriors', Rewi's rejection of a tohunga's 'Maori Gods', officers discussing strategy, 'Irishman gag dialogue', and Ben's words, 'We heard them [women and children] crying for the dead in the night' (AHMM, box 22). It may be because of this re-editing that the cue 'Haka of Defiance' is now missing.

The title 'Haka of Defiance' refers to an exchange of haka between Māori in the pā and approaching Māori reinforcements. As described by Maniapoto chief Tupotahi in Cowan's history $(1983,1: 382)$, defenders inside the pā performed a Kīngite haka that likened the Government to a land-hungry bullock:

$\begin{array}{ll}\text { He kau ra, } & \text { Oh, a beast, } \\ \text { He kau ra! } & \text { A beast that bellows__ } \\ \text { U__u! } & \text { Oo__oo! } \\ \text { He kau Kawana koe } & \text { A beast art thou, O Governor, } \\ \text { Kai miti mai te raurekau } & \text { That lickest in the leaves of the raurekau__ } \\ \text { A he kau ra, he kau ra! } & \text { A beast_oh, a beast! } \\ \text { U__u__u! } & \text { Oo__oo! }\end{array}$

In response the reinforcements chanted the Tūwharetoa chant 'Uhi mai te Waero'. In The Last Stand the sequence of haka exchange is shortened and Hayward's disembodied voice over explains for British audiences that Māori 'link their savage spirits over the distance'. But according to Hill's music by this stage in the original film the Savage stereotype was already being subverted.

To describe how Hill's 'Haka of Defiance' challenges Māori primitivism I rewind for a moment and describe the Crown motif, 'The British Grenadiers'. The 'Grenadiers' has been associated with the British Army since George Handel presented the march to the Grenadier Guards before the premiere of his 1726 opera Scipio, in which it featured ('Band of the Grenadier Guards - History' 2014). In Rewi it is fixed as an aural signifier for the Crown by a jaunty fife and drum tune during an establishing shot of a soldier writing 'HEAD QRS 60" Reg' over the Te Awamutu Mission sign, and in somber D minor woodwinds as a bullock draws an Armstrong gun towards the pā (example 6 below). 
Ex. 6. Rewi's Last Stand. Cue 19: 'Bullock Teams Drawing Guns', bb.1-12.
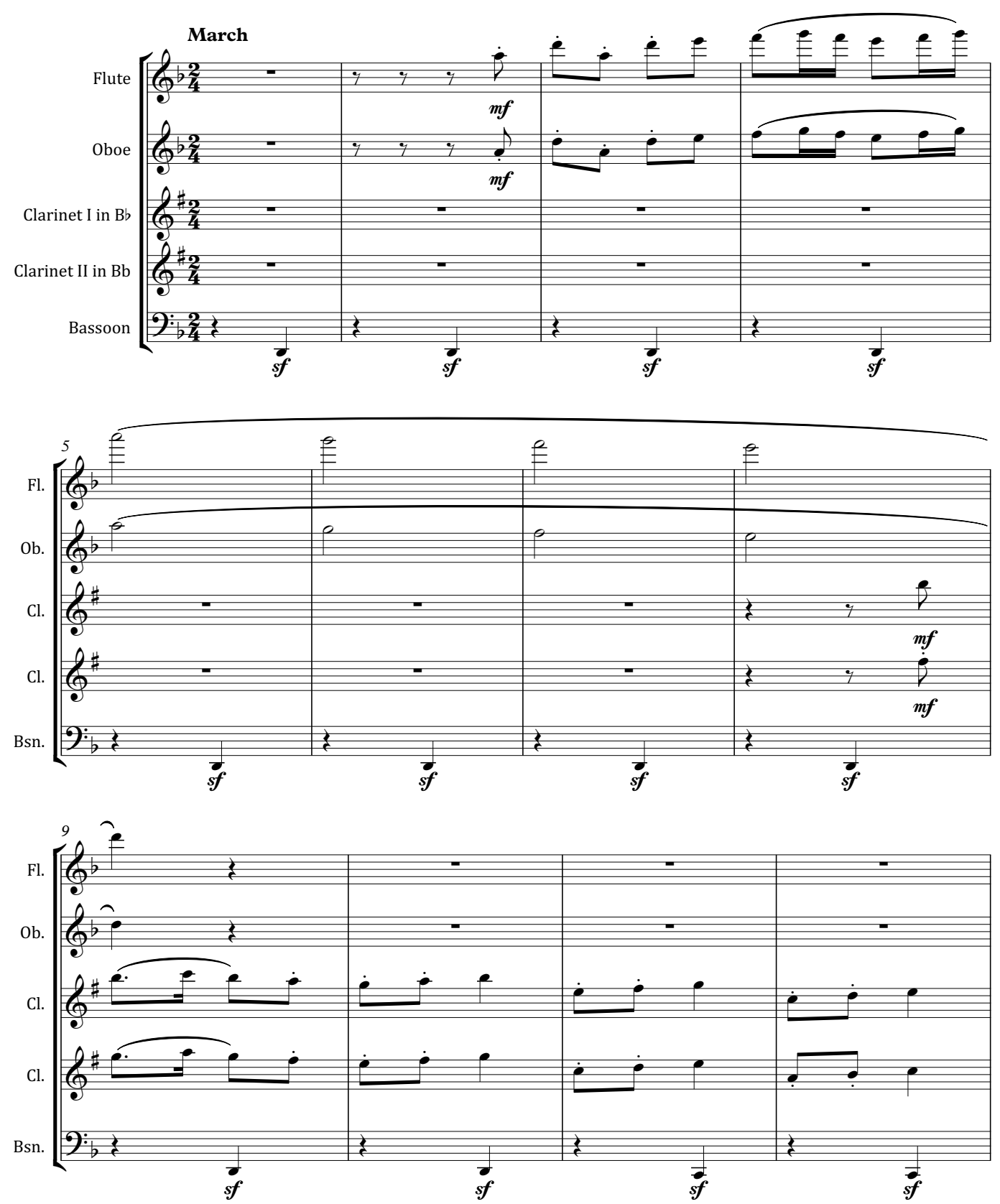

The Crown motif opens and pervades the C Minor 2/4 'Battle Music' cue but is altered to make a belligerent, semi-flattened three-note rhythmic motif (example 7 below). This rhythm accompanies the soldiers' march forwards towards the camera and a shot tracking along the line of Māori crouched ready in their trench. Then as Rewi surveys the battlefield the original melodic major mode Crown motif breaks through in the trumpet and modulates up in a sequenced 'bugle call'. Perhaps in a cross-cultural reference to the compound time of haka the tail of this melody is transformed into triplets to 'alert' the Māori force. This 'call to arms' and the following re-transition to the original key 
anticipate the bugler's diegetic call to charge. The battle commences, the semiflattened Crown motif returns - and Rewi as we know it abruptly cuts to a bugler recalling Crown forces.

Ex. 7. Rewi's Last Stand. Cue 21: 'Battle Music'. 'Crown' Motif, bb.1-3.

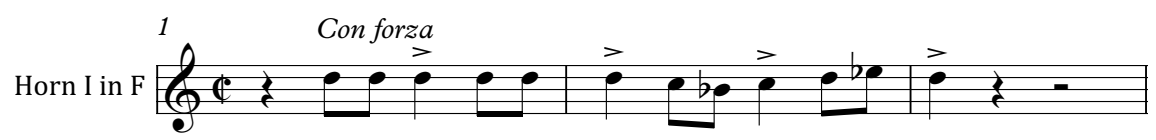

It would be reasonable to assume that in response to the Crown motif in 'Battle Music' and the narrative of haka exchange 'Haka of Defiance' would contain the Maniapoto motif - and it does, but not in its obvious form. The threenote figure makes an appearance in two altered forms: as a cadential figure where its scale degrees are governed by local harmonic requirements; and from bar 105 in a melodically flattened figure, in a similar treatment to that of 'Grenadiers' in 'Battle Music' (brass section extracted in example 8 below).

Ex. 8. Rewi's Last Stand. Cue 21a: 'Haka of Defiance'. 'Maniapoto' Motif, bb.105-108.

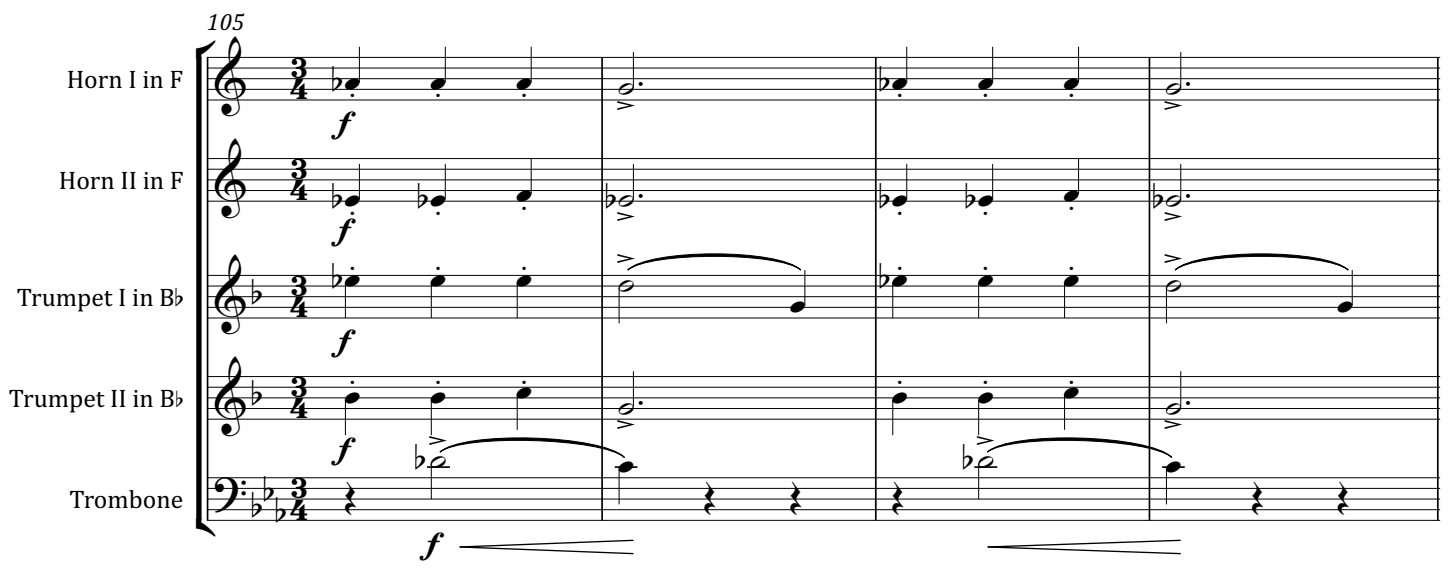

The accented syncopation in the trombone has the effect of making the motif's first note anticipatory and re-creates by augmentation the three-note rhythm of the Crown motif. The borrowing of culturally specific material between the battle cues and the 'shared' three-beat motif appears to symbolise desire for racial integration.

Hill's mixed cultural motifs support the Ōrākau myth, but rhythm alone by Hill's own reckoning connotes primitivism. I suggest that the primitivism in this cue does not only represent Maniapoto. While the haka triplet figure in 
'Battle Music' has no effect on the Crown motif after their 'encounter', in 'Haka of Defiance' a completely melodically flattened Crown motif in the brass, timpani, and lower strings running against the grain of the triple time signals radical change (brass section extracted in example 9 below). It heads a climatic passage characterised by extreme range and volume, the introduction of cymbal and bass drum, and a flute figure which heralds an eventual modulation to the (appropriately enough) subdominant minor. In this way in an act of imperial barbarism the 'Crown' forces its monotony onto the following flattened Maniapoto motif, turning what was a cadential figure into a theme of finality and a metaphor for the process of colonisation.

Ex. 9. Rewi's Last Stand. Cue 21a: 'Haka of Defiance'. 'Crown' Motif, bb.41-44.

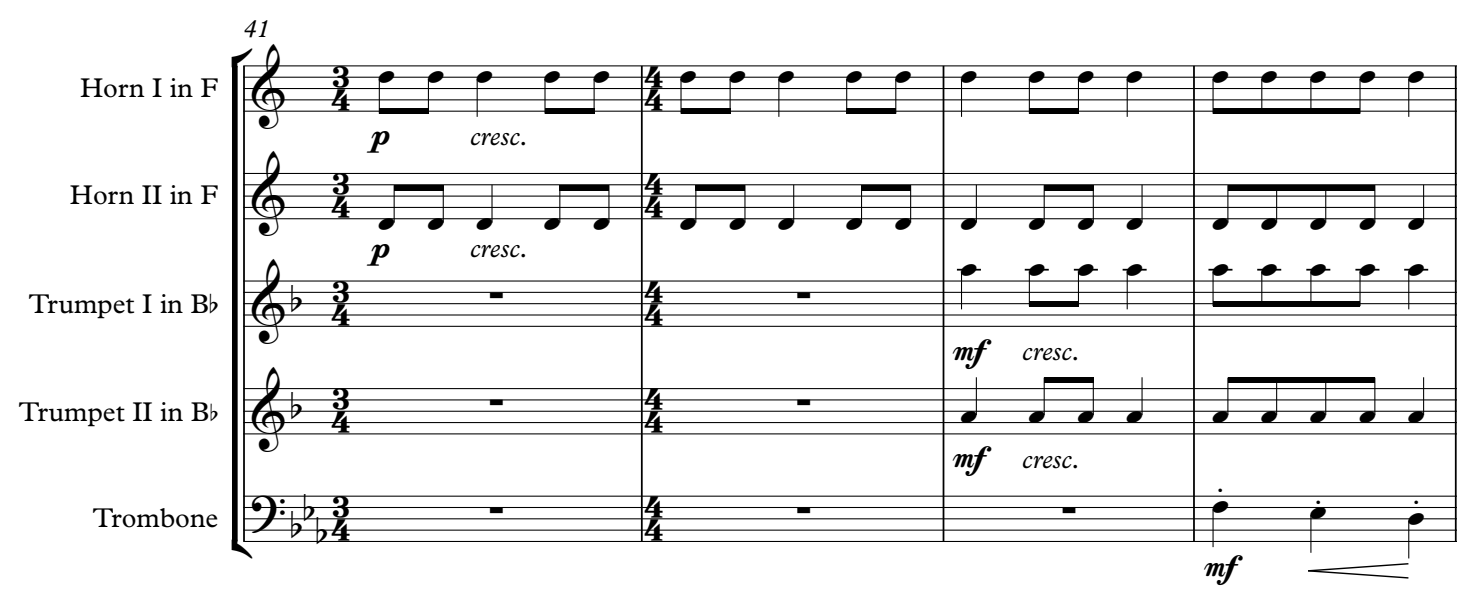

The mood of 'Haka of Defiance' also describes the reality of violently achieved cultural assimilation. With its relentless, repetitive rhythms, long sweeping phrases, cycling harmony, and lack of melody its character is tragic and reflective; the battle's outcome a fait accompli. Although there may be 'haka rhythms' in the music (Hayward 1960), there is no defiance. Hill may have used the technique of anempathy here, a film music technique whereby the mood of the music is in direct contrast to the onscreen action producing a sense of tragic irony. No wonder this scene was cut short for British audiences. For a New Zealand audience buying into the myth of Progress founded on historical racial conflict it makes more sense. Only from a truly monstrous event such as internal war can a harmonious nation be born.

Hill's final cue ostensibly representing Maniapoto as they escape Ōrākau Pā at the close of the battle, 'Maori Defiance', is loosely in the style of a Baroque 
fugue as defined by Paul Walker (2001, 319). A five-bar-long fugue subject in F Minor enters in the bass instruments accompanied by a dark continuous timpani trill as Māori realise their desperate position and prepare to leave the pā. Next the answer is presented in the mid-range instruments in the dominant key (cello subject and violin I answer extracted in example 10 below). The high woodwinds, strings, and trumpets conclude the exposition with a restatement of the subject. The middle section of the cue breaks from the style of Baroque fugue by introducing a new theme that recalls the flattened Maniapoto motif. The bass instruments then reintroduce the fugue subject in the tonic. Unusually, the last full statement of the subject is in the dominant key. To find a fugue in film music is rare and I argue that Hill's decision was quite deliberate. Blythe's (1994, 3-5, 7) description of the three ways in which Pākehā imagined the racial other in early New Zealand film, i.e., stereotyping, naming, and temporal distancing, can explain why Hill made this choice.

Ex. 10. Rewi's Last Stand. Cue 29: 'Maori Defiance'. Fugue subject, bb.1-10.
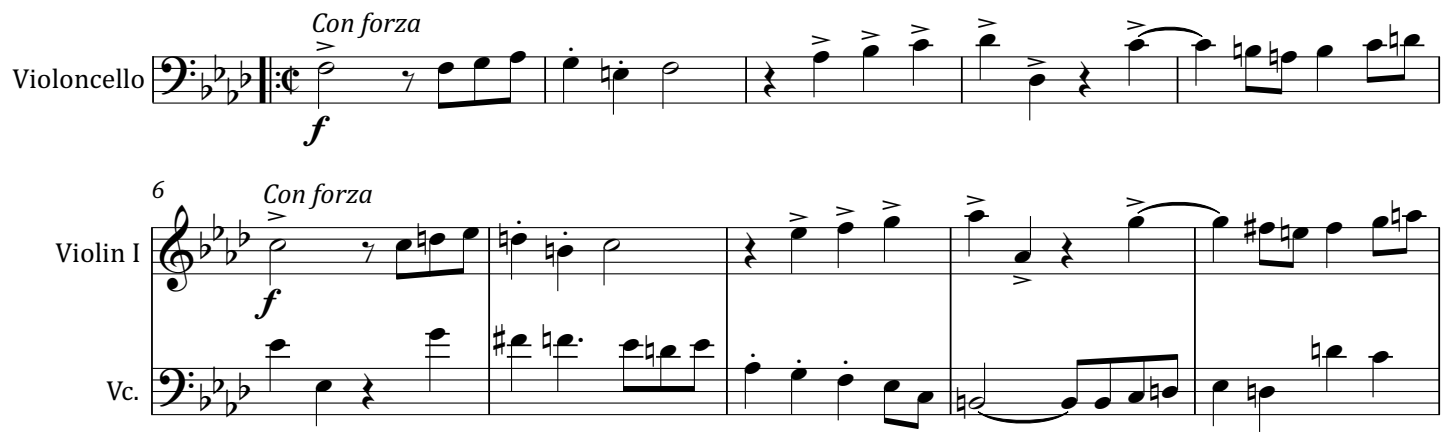

Hill needed to reverse the effect of his initial Indian stereotype and encourage the audience to imagine Māori as the Pākehā self. To 'raise' Māori he represented them with a stereotype of civilised European culture. Fugue's association with intellectualism and learnedness stretches from the sixteenthcentury Italian ricercar's function to 'search out' or 'research diligently' thematic repetition through to its nineteenth-century revival by the 'musical cognoscenti' by way of the eighteenth century's 'Golden Age' of German fugal writing and treatises (Walker 2001, 322-330). During the nineteenth century the German theorist F.W. Marpurg defined fugue by its 'Harmonie' or 'vertical sonority rather than horizontal part writing' (ibid., 329). The harmonious counterpoint of fugue signified for Hill harmonious relations between equally 'evolved' races, 
and through this cultural assimilation masquerading as political bicultural integration he upheld Hayward's civilising mission.

The fugue appears to thematically support this musical conversion. On the small scale the 'primitive' accented syncopated scale figure and leaping (perhaps hopping) octave of the subject's third and fourth bars is preceded by notes that define 'rational' tonality and followed by the Crown motif. This containment is reflected on the larger scale where the Maniapoto-like rhythmic motif and Crown motif 'battle it out' for dominance in the middle section, while the 'civilising' fugue subject imposes order from without, its final dominant presentation preparing eight bars of resounding almost entirely 'home key' tonic notes. Primitivism is subdued, and the racial other is admitted to the mysteries of western art music, redefined as the Brown Briton, and enters into modernity and a Pākehā-defined home present.

However, while the fugue connotes civility, an examination of language uncovers the reality of this historical event and the irony of Hill's choice. The word 'fugue' can be traced back to the fourteenth-century 'fuga', 'to flee', and 'caccia', 'to chase' (Walker 2001, 318). This refers to the imitative characteristic of canon, but in Rewi also mimics the onscreen action of the opposing forces. After three days without food and water, Māori defenders break out of Ōrākau Pā and are hunted across open country by Crown forces, bayonetted, and shot. In Rewi 'Song of the Locust' first helps to construct a fictional chase by an aggressive indigenous enemy, but by the film's closing moments it has been deconstructed and comes to describe the reality of horrific British pursuit. The fugue's representation of rational civility and the Crown motif's cultural allusion to a tradition of honourable British military service appears to absolve British forces at the moment they commit their worst atrocities.

The stark reality of internal interracial violence was in part ameliorated by another connotation of the fugue - that of temporal distancing. Since the nineteenth century fugue revival when fugal theory became increasingly orientated towards the past and composers studied in particular J.S. Bach's keyboard fugues, the fugue has been seen as an archaeological relic (ibid., 330). 
This temporal distancing cushioned the shocking reality of historical conflict during a period when Māori and Pākehā were once more engaged in war by lending the scene a romantic, timeless quality and relegating the battle of Ōrākau to the legendary moment of the nation's birth.

Kiri Te Kanawa, 'Tarakihi', and Māori Land

The original haka 'Song of the Locust' alluded to the potential for transformation. Hill's adaptation shows just how much potential it contained when confronted by the effects of colonisation. What began as the cicada's call became a Māori song, then a 'Māori' song, and then 'Māori Indian', 'Maniapoto', and safely contained primitive motifs. We may hear the first transformation from insect to Māori haka as 'authentic Māoriness' in its 'essential pre-European' qualities, and all the following imagined collective identities as solely colonial imaginings, but imagined communities are political constructs with fluid boundaries, always forming and reforming in response to individual experiences at any given time and place. Like 'Home, Little Maori, Home', from its time of publication Hill's arrangement of 'Song of the Locust' held cultural significance for Māori and it seems the Hill's treatment of the song in Rewi did not detract from this; indeed it may have enhanced it.

Initially both Pākehā and Māori performed 'Song of the Locust' in various cultural contexts. In 1928 Ernest McKinlay's bilingual commercial release was favourably reviewed in the New Zealand Herald (22 December), and from this year it was performed live on the radio, for example by Madame Gower-Burn's Grand Operatic Quartet ('Wireless Programmes', New Zealand Herald, 15 February 1928, 15). Throughout the early 1930s it was included in public Wellington concerts, for example Trevor Thomas performed it during 'Authors' Week' in 1936 (Evening Post, 23 April, 4). In 1939, perhaps due to Hill's temporary residency, it seems to have been popular in Auckland: McKinlay performed it on 1YA on Anzac Day (Evening Post, 24 April 1939, 6); boys of the Anglican Māori school St Stephen's sang it at an inter-school festival (Auckland Star of 17 August 1939); and in August Alfred Hill performed it himself with the 'Alfred Hill String Quartet' on 1YA ('Today's Broadcast Programmes', Evening 
Post, 16 August 1939, 17). In the wake of a return season of Rewi to Wellington, Henare Tahiwi (Ngāti Raukawa) sang 'Song of the Locust' at two patriotic Ngāti Poneke concerts at the Wellington Town Hall ('Maori Entertainment' 1941). ${ }^{44}$

In contrast, from the 1960s 'Song of the Locust' was almost exclusively recorded by Māori, nearly always under Māori titles, sometimes as a choral item, and often accompanied by guitar. ${ }^{45}$ These performers often, but not always, had links to the Waikato. For example, Inia Te Waita (Ngāti Raukawa) sang 'Tara Ki Hi' on Maori Songs (1962), attributed erroneously to Kaihau; Hinerangi Deller (born Hikuroa) arranged the song as 'Ta Ra Ki Hi' for the Maniopoto [sic] Voices (1966), attributed as traditional; and Kelly Koroheke of Waitomo performed a very slow version called 'Waiata-a-Te-Tarakihikihi' on the group He Toa Takitini's Maori Music from the Waikato (197-). This last recording describes the song as a 'classic Maori chant', but its title, which literally translates the original, describes best its transformation from recited haka to modern waiata.

There was a decline in recordings of 'Tarakihi' during the final decades of the twentieth century, but this changed in 1999 when London-based Kiri Te Kanawa (Ngāti Maniapoto; Ngāti Porou), who remembered hearing The Maniopoto Voices sing the song during the 1960s, decided to include it on her CD Maori Songs (Max Cryer pers. comm. 10 April 2014). ${ }^{46}$ As of June 14 2014, Te Kanawa's website (damekiritekanawa.com) includes a promotion for her new CD Waiata in which she describes these latest Māori songs (which include some 'nice lullabies') as modern, nostalgic, and singable. Te Kanawa says of the experience of making this CD that it was lovely to come home to 'sing your own music in your own country'. Her comments suggest that for her the modern waiata she sings represent her nation and her Māori ethnicity.

\footnotetext{
${ }_{44}$ The programme for these concerts features Te Miha on the cover, suggesting she had contact with Ngāti Poneke during her earlier brief residency in Wellington.

${ }^{45}$ As 'Pakia Kia Rite', it should not be confused with Kingi Tahiwi's 'Aue e Te Iwi e/Pakia Kia Rite', often reduced to 'Pakia Kia Rite'.

46 Margaret Orbell was studying 'Song of the Locust' at this time (Max Cryer, 19 February 2014, pers. comm.). Te Kanawa may have heard this group when she visited Te Awamutu for the Ōrākau centenary commemorations.
} 
Carl Doy arranged 'Tarakihi' for Te Kanawa. To balance the quieter lullabies on Maori Songs he added a Māori choir and a drum track to emphasise the song's irregular phrasing (figure 5 below) (21 May 2014, pers. comm.). Aware that 'there are no traditional Māori drums' and certain he did not want a 'Pacific log drum' sound, Doy thought 'a modern rock kit with heavy tom toms would work well', but in the London studio the drummer added slapstick. Doy has since been asked on many occasions if this slapstick is the sound of a traditional Māori instrument. Despite the addition of what could be imagined as Polynesian drumming, Doy feels 'Tarakihi' has an innate 'Māoriness' because New Zealanders recognise the lyrics as Māori, and the 'choir's vocal performance and chanting is so strong that it couldn't be anything but Maori' (ibid.).

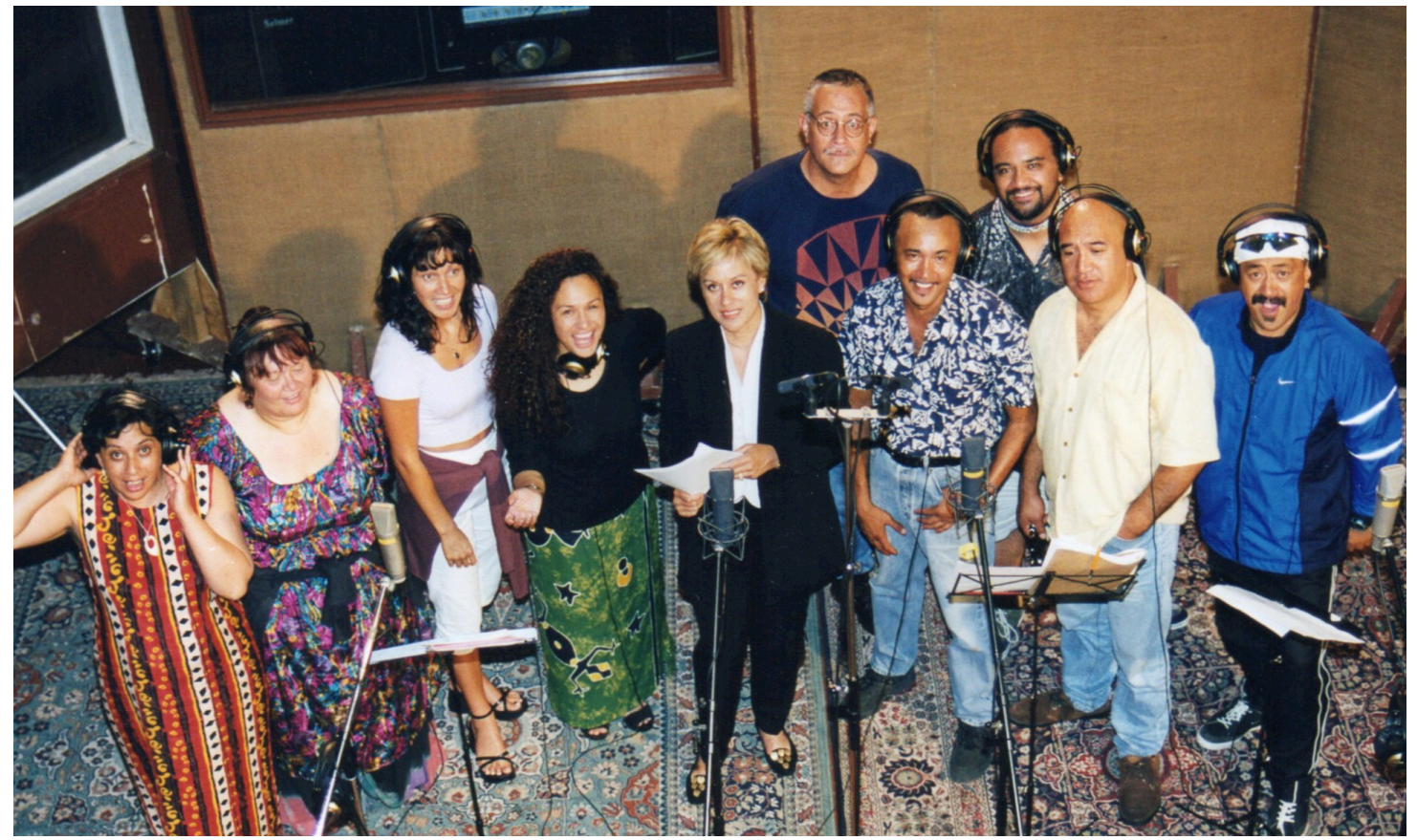

Fig. 5: Kiri Te Kanawa (centre) with (L to R) Mahinarangi Tocker, Mahia Blackmore, Taisha, Cathy Reti, Dilworth Karaka, Peter Morgan, Robert Wiremu, Armand Crown, and Tom Napier. 1999. Courtesy of Max Cryer.

New Zealand audiences may indeed consider that 'Tarakihi' represents a Māori collective because of the use of Māori language. While McKinlay performed the song in both Māori and English, as during the 1960s today it is only performed in Māori. They may also consider 'Tarakihi' a Māori song because certain ethnic identities are highlighted and obscured in recent recordings. Te Kanawa's version is described as an 'ancient Maori chant by an unknown composer'; The National Māori Choir, who have performed with Te 
Kanawa, recorded it in 2000, unattributed; Elena Te Nahu (Ngāti Kahungunu) recorded it in 2003 and attributed it to Maniapoto, Hill, and Doy; ${ }^{47}$ and Elizabeth Marvelly (Te Arawa) recorded Doy's arrangement in 2007, attributed as traditional. Since the 1960s most recordings have been made by Māori women and although Doy is often cited in recordings since 1999, Hill's contribution has been mentioned only once since McKinlay's 1928 release.

Additionally, Māori, and in the wake of the Māori cultural renaissance some culturally aware Pākehā like Doy, may recognise within 'Tarakihi' other features strongly characteristic of Māori music. Hill's opening irregular threebar phrases, which Doy wished to make a feature of, are perhaps interpreted as the 'quaint' phrasing characteristic of early twentieth-century 'transitional' Māori songs (McLean 1996, 311), while the monotonous cicada call and syncopated rhythms remain easily recognisable characteristics of haka, despite Hill's arrangement. Hill's musical Indianism too may be heard as syncretic with characteristics of haka: the accented downbeat of the three-note motif within the triple time recalls the strong internal pulses within haka's compound metre often accompanied by stamping and slapping, while the closing Indian 'hopping fifths' could be reinterpreted as whakaū.

The Māori musical characteristics of 'Tarakihi' have implications for the original audience of Rewi. As described above, due to the anempathetic mood of 'Haka of Defiance' and foreknowledge of the battle's tragic outcome I interpret the monotonous rhythm from bar 41 as a dominating version of the 'Crown' motif that connotes colonial oppression. For original Māori audiences in particular, however, who recognised both the musical characteristics of haka and the 'war-like sound' of Hill's popular song in 'Canoe Pursuit', and were familiar with narrative details of this battle, this motif may have been heard as the cicada's call. As such it may have represented both historical and twentiethcentury resistance against Crown injustices under the Treaty. Despite these contrasting interpretations, Hill appears to have had an idealised, integrated nation foremost in his mind - the same monotonous repetitive rhythm

\footnotetext{
${ }^{47}$ Although there is a tantalising linguistic connection between the word 'tarakihi' and the town of Kihikihi, Te Nahu's attribution to Maniapoto is unsubstantiated at this time.
} 
accompanies Robert's much earlier victorious 'bicultural' taiaha fight against the Ranger swordsman (see Chapter Three), before the 'Grenadier' tune is introduced.

In the nature of imagined communities, many New Zealanders today may also regard 'Tarakihi' as both a Māori song and a sign of bicultural nationalism. As of 23 May 2014 Doy's website (http://www.carldoy.com/biography/page2) states that Te Kanawa's performance at Gisborne on New Year's morning 2000 was broadcast to a live televised audience of approximately one hundred million people. For some this 'Māori war song' song now commemorates New Zealand's place as the 'first country to welcome the new millennium'. Doy notes that since then 'Tarakihi' has become a regular item in pre-game entertainment at international rugby tests (Doy, 21 May 2014, pers. comm.). In this latter example the combative atmosphere of sport, Māori song, and 'Māori' song join together to apparently break down racial segregation in New Zealand society.

Te Kanawa's recording also appears on government broadcast funding agency NZ on Air's Iwi Hit Disc (2000). This is one of a series of initiatives that ostensibly targets specific broadcasters and audiences, for example: Iwi Hit Disc (indigenous radio stations), Kiwi Hit Disc (pop and rock stations), and Indie Hit Disc (breakout artists) (Neill 2005, 155-156). However, NZ on Air's music manager Brendan Smyth makes it clear that Hit Disc songs are selected for commercial appeal to promote a local, i.e., New Zealand, music industry (ibid., 156). Iwi Hit Disc is described on its coverslip as a compilation of Māori songs selected for their 'potential to crossover to mainstream radio'. In an echo of 1920s government broadcast propaganda, NZ on Air fixes a song between Maoriland and Māori land to the nation.

In response to the high profile of 'Tarakihi' as a representation of 'New Zealandness' we might expect a resurgence of Pākehā performances of this song. Certainly, some non-Māori choirs have performed it live. As of June 142014 the Womansong Choir includes 'Tarakihi' in its 'Aotearoa NZ and the Pacific' repertory (http://www.carolshortis.com/Carol_Shortis/choirs/womansong). The term 'Aotearoa NZ' attempts to negotiate what Blythe $(1994,6-8)$ describes 
as a 'schizophrenic' double bind of power: Pākehā recognise ethnic or apply racial difference and Māori are segregated ('Aotearoa'); simultaneously Māori are integrated under the Treaty ('New Zealand'). This identity oscillation may be a contributing factor as to why there appears to be no recently recorded Pākehā performances of what today appears to be on balance a song of Māori land.

\section{Conclusion}

In the early twentieth century Stowell shared 'Song of the Locust' with Hill and others in the spirit of greater interracial understanding. In his twin desires to preserve Māori culture and create New Zealand, Hill arranged this haka as a popular song. In Rewi the song's potential as a site of Maoriland identity formation was taken to an extreme with Hill's application of western musical stereotypes of the Savage warrior and European civility. Hill's song was not associated with a particular ethnicity or iwi before 1940 but possibly in response to its prominence in Rewi it afterwards became a popular item among Waikato Māori, perhaps as a sign of affiliation with the Māori defenders of Ōrākau and those who portrayed them on screen. Since 1999 'Tarakihi' has been re-claimed largely by Māori women to represent a gendered ethnicity. Today Pākehā communities and government agencies continue to use the 'Māoriness' of this song to construct their own sense of the nation through Maoriland, although in less overt ways than in Hill's time. It seems a shame, however, that while today Māori recognise and celebrate 'Tarakihi' as a taonga, over the past sixty years Pākehā have forgotten their identities represented in this song. 


\section{Conclusion.}

I approached Alfred Hill's 'Māori' songs with trepidation. In my preliminary reading I learned that Hill's music was considered by scholars largely as sentimental Victorian dross or anachronistic Romantic art music; that it was music of the frontier: distant from, peripheral to, and paradoxically dependent on imperial cultural centres; and that Hill's 'Māori' music did not represent early twentieth-century New Zealand in musical style or ideology because these concepts did not (yet) exist in the local context. I learned very little about Hill's 'Māori' songs at all. I was afraid I would find these and Hill's film music to be musical signs of colonial hegemony masked as popular entertainment of inferior quality - thereby condemning him on both old and new fronts. This fear was founded in ignorance. When I 'got past' what other people had said about Hill I began to find him for myself through his music, his words, his homes, and his communities. Hill's 'Māori' songs are music of the frontier, but not one familiar to most Hill scholars.

My analyses of 'Home, Little Maori, Home' and 'Song of the Locust' were based on two main theoretical concepts: Firstly, imagined communities that appear to describe ethnic, racialised, gendered and national collectives but in reality are individually imagined political constructs inhabited by no one. Secondly, the two predominant British settler myths of origin: Progress and Paradise; Paradise configured in the local context as Maoriland, an imaginary site of Pākehā identity formation, made tangible in cultural artefacts, within which notions of 'them' and 'us', 'them as us', and 'us as them' are worked out in past, present, and future homes made by Pākehā for Pākehā, for Māori, and at times for Pākehā and Māori to live in harmoniously together.

This thesis has shown that through his respect for Māori, his drive to save 'real' Māori music, and his perceptions of race, Hill produced Maoriland songs that contributed significantly to the ethnic, gendered, and national identities of himself and other Pākehā, and further to a nexus of Māori, war, and music that upheld Pākehā narrations of the nation, especially in the case of his score for Rewi's Last Stand. When Pākehā heard 'Māori' war songs in the early twentieth 
century in connection with World War One, commemorations of this war and the battle of Ōrākau, and sport such as lawn bowls, they in effect reimagined the myth of Ōrākau; a myth which serves to express the desire for a post-colonial nation. When we open our eyes and ears to Maoriland, however, we begin to find it everywhere. As a Pākehā, I interpret the young smiling Māori women dressed in kahu kiwi drenched by the rain and standing inertly behind International Rugby Sevens winners receiving their medals, in the wake of Māori 'warriors' blowing Pūtara, as Maoriland maidens. Maoriland will remain part of Pākehā narrations of the nation for as long as New Zealanders uphold the Treaty of Waitangi as a bicultural framework for the nation, negotiate decolonisation, and produce historiographies of war - that is for the foreseeable future.

Hill's 'Māori' songs are, however, artefacts of cultural colonisation that demonstrate the ambivalence of both Pākehā and Māori individual identities and imagined communities. In the first half of the twentieth century Hill was a member of a 'knowledgeable group' (Ballantyne 2012, 187) of collectors, composers, scholars, and performers of New Zealand songs with Māori themes and musical materials. This community includes but is in no way limited to Knocks, Ngata, Best, Andersen, Papakura, Te Rangi Pai, Kaihau, Stowell, Cowan, Walsh, McKinlay, Te Waita, and Williams. While members of this community corresponded on the subject of Māori music, in practice they often made little distinction between the ethnicities (even in some cases such as 'Home Sweet Home', the nationality) of composers or performers of these songs. As such Hill's 'Māori' songs appear to form part of a specific early twentieth-century crosscultural New Zealand song genre. A challenge for future researchers is to develop a language that can express the in-between homes they live in.

Many members of this community were cultural go-betweens, and I argue that for approximately twenty years from the early 1890s, through his time spent with Māori communities and individuals Hill was too. This study has reconfirmed his longstanding relationship with Tūhourangi, and suggested that he also knew members of Ngāti Raukawa at Ōtaki and politically influential individuals in Wellington. It has also raised the possibility that his relationship with Tūwharetoa began long before his visit to Taupō in 1930. Early 
relationships between Hill and other iwi are unknown at this time. It seems he did not take up Goldie's invitation of 23 October 1916 (AHPP, box 2) to accompany him to Ruatoki in Tūhoe territory to collect 'the real stuff', but on 20 April 1938 the Auckland Star reported that James Carroll had once introduced Hill to the Tūhoe prophet Rua Kēnana, who praised his work. The cultural gobetween may provide a useful context for future research of early twentiethcentury Pākehā Māori music by Hill and others.

More study is required through archival research and time spent with Māori communities before it can be claimed Hill retained the status of cultural go-between after he committed himself to a career in Sydney from 1916. During later visits to Māori communities at Tūrangawaewae and Rotorua he was received as a person who embodied significant mana (prestige), and although not bilingual he retained the ability to move easily between Māori and Pākehā worlds. As integrationist policy strengthened during the first half of the twentieth century speaking Māori was actively discouraged and English became the dominant language of internal commerce, politics, and education for all New Zealanders. Therefore the definition of a cultural go-between from this time may need to be adjusted to include Pākehā like Hill and Hayward who although not fluent in the Māori language in other ways attempted to learn the customs and intentions of Māori people.

The hegemony of Maoriland is unlikely to be redressed by Pākehā, but it may be eroded by recognition that Māori have always lived in contemporary New Zealands. This thesis supports the findings of studies in other areas of the arts (Blackley 1997, 44-55; Petersen 2000, 69-71; Gibbons 2002, 15; Diamond 2007, 18; Mita 1992, 36-39; King 2008, 2; Wanhalla 2011, 116) that show early twentieth-century New Zealand was itself an 'in-between' place where Māori engaged with Pākehā artefacts of cultural colonisation to negotiate their own homes past and present and define individual and communal identities. Māori musicians and music scholars operating within Maoriland attempted to 'reach a conciliation with the expanding British-Pakeha nation' (Blythe, 1994, 17) by choosing between English or Maori language for their compositions, performances, correspondence, and personal names. Examples include 
performers of Hill's bilingual songs such as Princess Iwa also known as Eva Skerritt, Ana Hato, Makereti (Maggie) Papakura, also known as Margaret Thom and Mrs Staples-Browne, and Ramai Te Miha, also known as Patricia Miller and Ramai Hayward; the composers Maewa Kaihau, also known as Louisa Flavell, and Te Rangi Pai, also known as Fanny Howie; and the scholars Āpirana Ngata and Henry Stowell, also known as Hare Hongi.

This indigenous escape from Paradise and Progress through the power of language continues today. An exhibition in the Te Arawa Hall at Rotorua Museum, which presents early twentieth-century artefacts of cultural tourism such as Hato's discs of Hill's songs, is named 'Welcome to Māoriland', while in 2014 Ōtaki was home to the inaugural indigenous Māoriland Film Festival, referring to the town's short-lived 1920s Maoriland Film Company. The addition of a macron to the word 'Maoriland' in these examples demonstrates the power of renaming to challenge the colonial hegemony of past Pākehā narratives of the nation. For me the most powerful example of indigenous naming that came to light during this study, however, is the reclaiming of 'Song of the Locust' by Māori as 'Tarakihi'. This 'saving of Māori music from oblivion', as Hill might have put it, has been so complete that his own place in the history of this song is now obscured. Māori claim their cultural heritage while Pākehā lose part of theirs and the soundtrack of Maoriland is forgotten.

Other themes have become apparent during this research. I have found that there are general ethnic and gendered characteristics to the make up of the knowledgeable group identified above that support the recent gender and postcolonial scholarship of Ballantyne and Burton (2009), Cooper (2013), and Wanhalla (2013). Examples are to be found in the Pākehā men and Māori women who make up of the parentage of Māori women performers mentioned above and particularly in the relationships between Hill and Papakura, Hayward and Ramai Hayward, Cowan and Eileen Stowell, and Knocks and his wife. These examples appear to illustrate the association between the joy and anxieties embodied in the Maoriland maidens of Hill and Hayward's texts and those of the lived experiences of interracial social and sexual intimacies between Pākehā men and Māori women during an era of political racial integration and social 
racial discrimination. As such the imagined communities of ethnicity, race and gender seem useful approaches to further study of Hill's music of interracial affection.

The most unexpected theme that emerged from this study for me was the extent to which Hill's 'Māori' songs and Hayward's Rewi were co-opted by the formal culture of government to uphold bicultural nationalist ideology. This seems to have begun in the mid 1920s with the Waitangi Day radio broadcast that mixed Maoriland and Māori music and the Education Department directive to sing Hill's 'Māori' songs in schools, and continued in the government's support of the production and promotion of Hayward's Rewi and its further wide dissemination through school screenings during the 1960s (Hayward c.1971). While Hill advocated for a national symphony orchestra, a conservatorium for art music, and various institutes for indigenous music his cross-cultural popular songs and film music were at work constructing the nation. A study of historical or more recent Maoriland music in the context of formal and popular institutions and texts, including audiovisual texts, would be a fruitful area for further research of New Zealand's musical nationalisms.

While my argument has focused on Pākehā identity formation, the stories of Hill's Maoriland songs are cross-cultural and their study must be approached from a bicultural position to interpret the power relations of recolonial and decolonising societies. In recognition that Māori are either integrated into Pākehā texts under Pākehā nationalist ideology or segregated in reflection of social realities (Blythe 1994, 8-9), I have combined these approaches, offering an integrated reading that privileges personal Māori and Pākehā stories. Early twentieth-century cross-cultural New Zealand music, which can tell us so much about our past and present identities, seems an ideal area of research to put this approach further to the test. 
Appendix I

\section{Explanation of Reconstructed Cues}

The following appendices consist of three cues from Rewi's Last Stand that I have reconstructed from orchestral parts held in AHMM, box 23. These are intended solely as an aid to the analysis within this thesis. They are only lightly edited to indicate Hill's working method. Inconsistencies in editorial style within and between parts are largely retained, obvious mistakes and omissions are corrected, and rehearsal annotations are omitted. 
Appendix II

\section{Rewi's Last Stand}

Cue 12 'Canoe Pursuit'

Alfred Hill

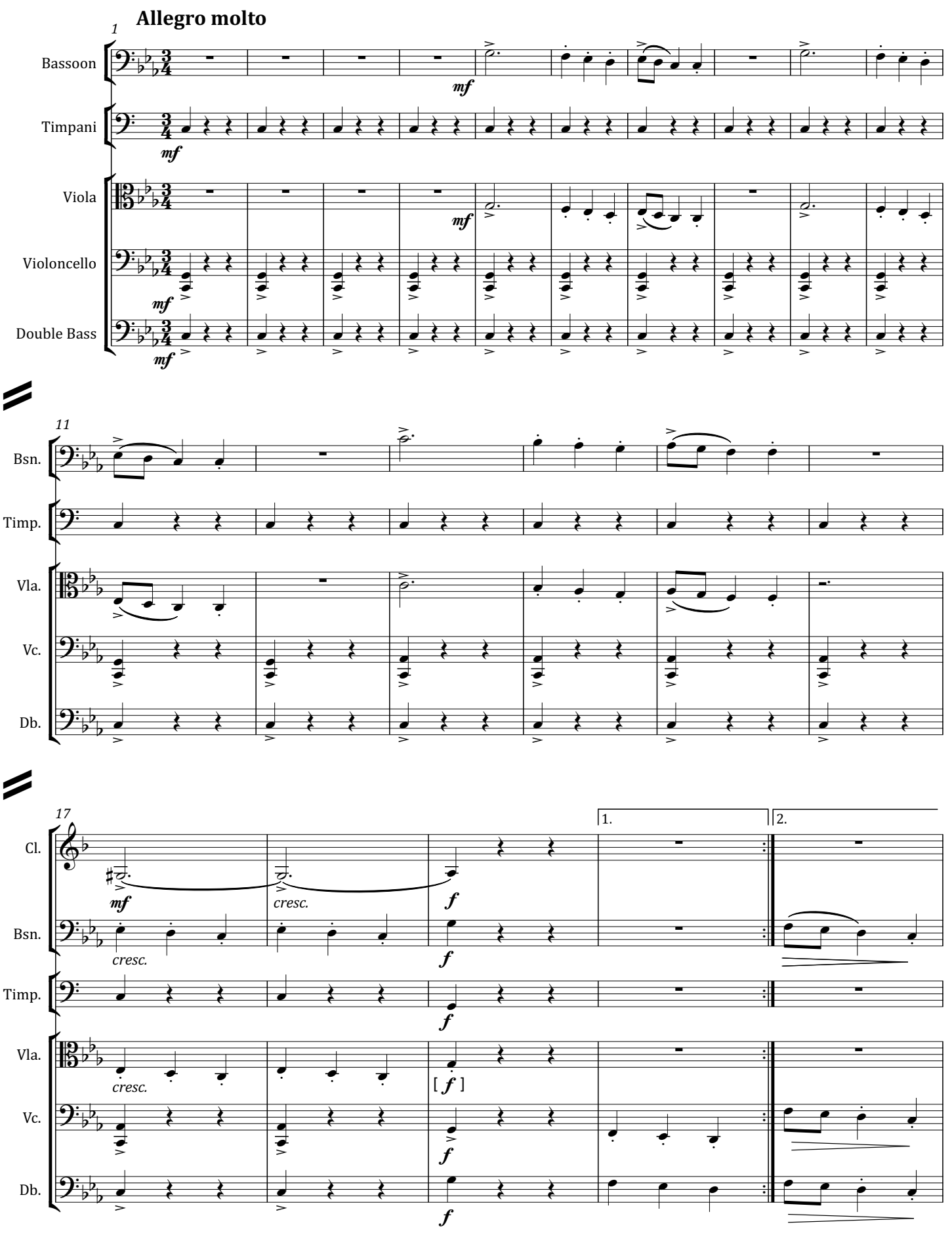



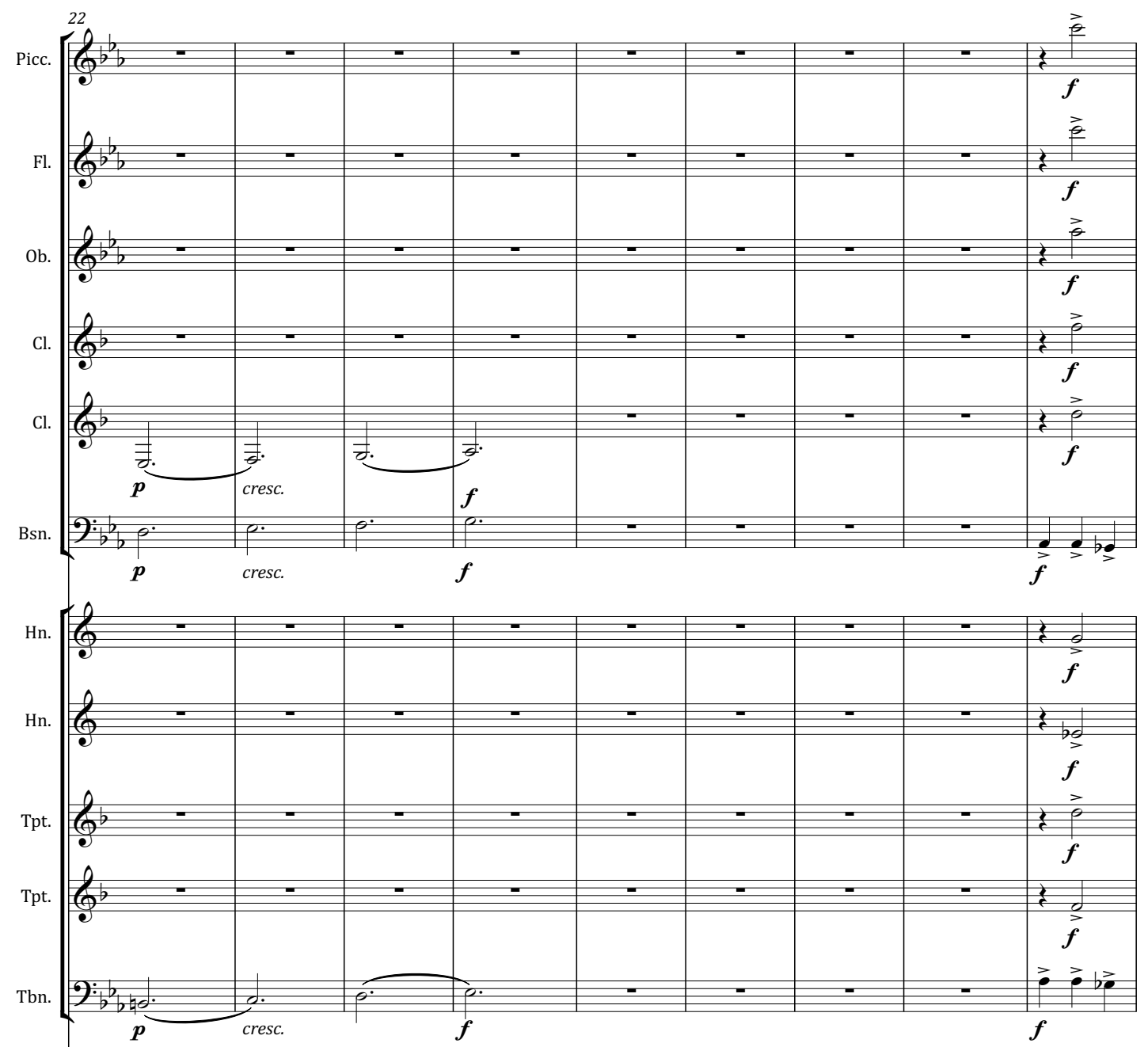

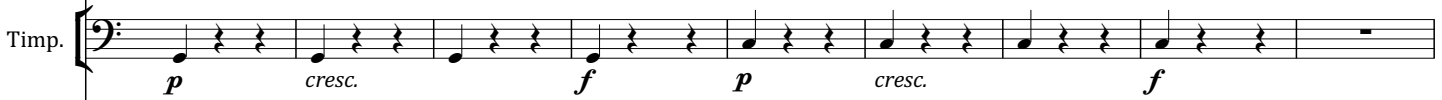

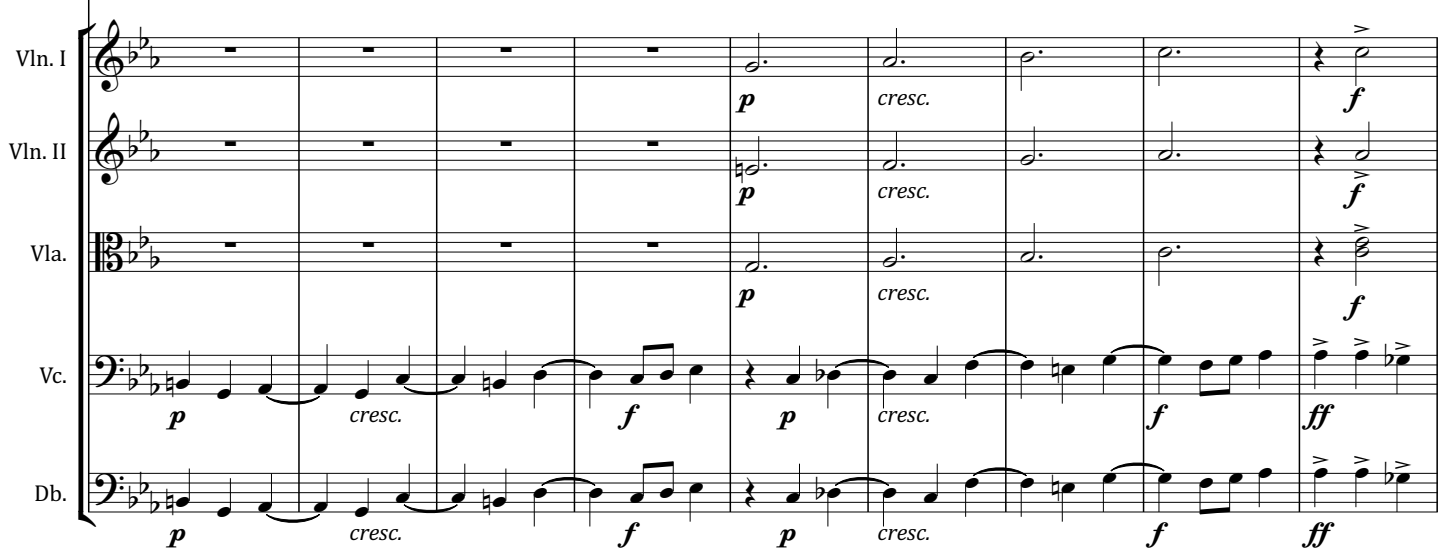



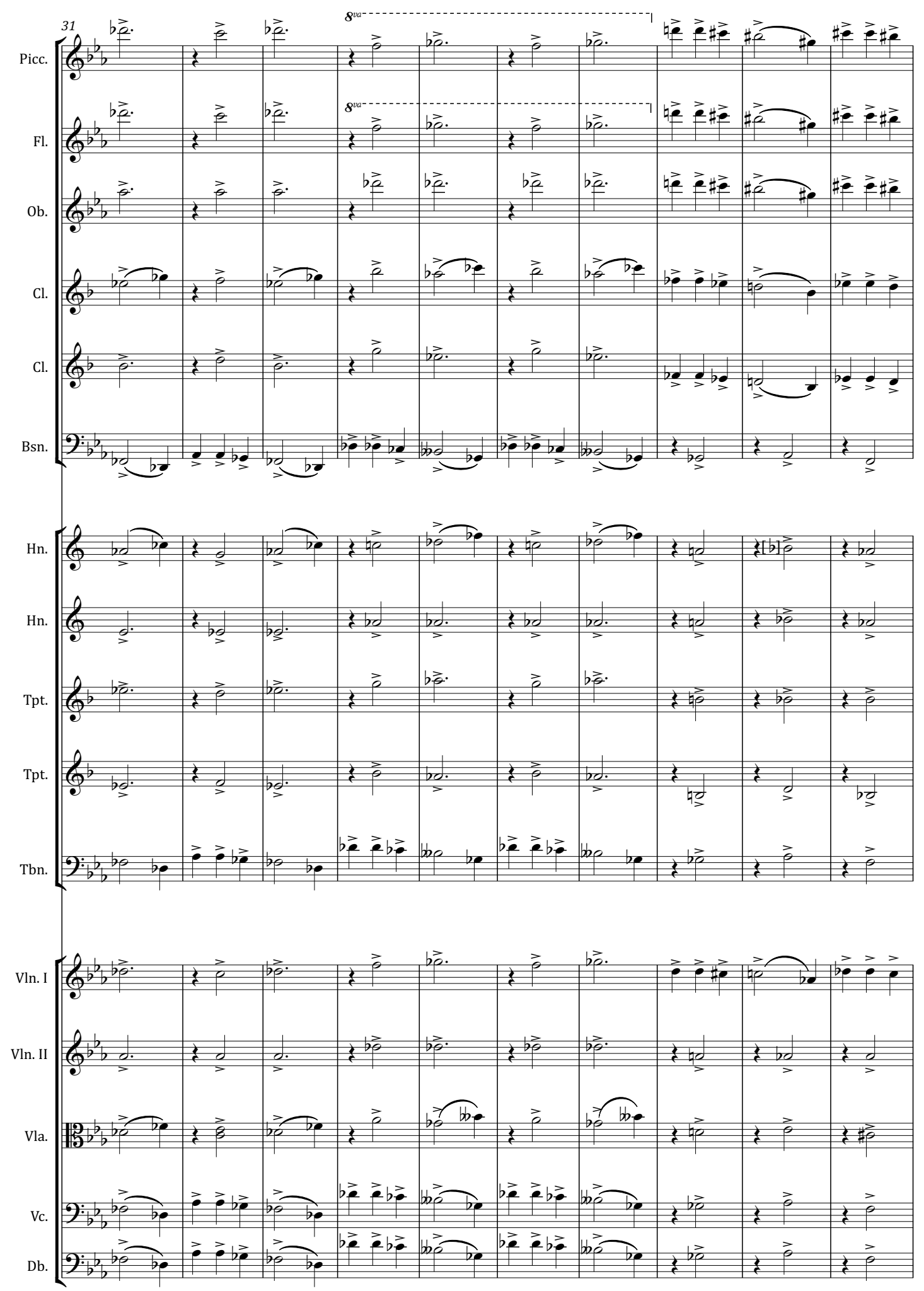

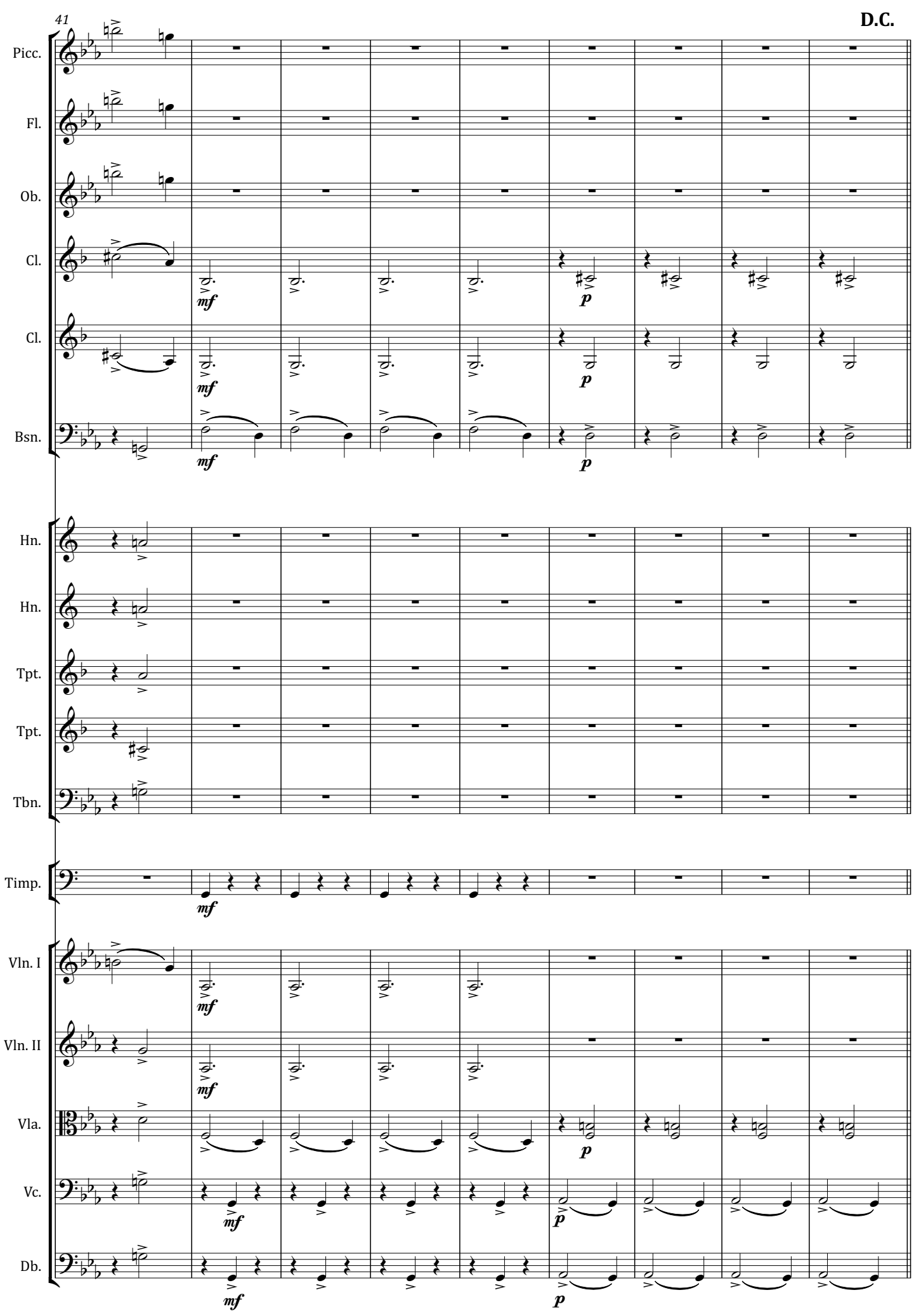


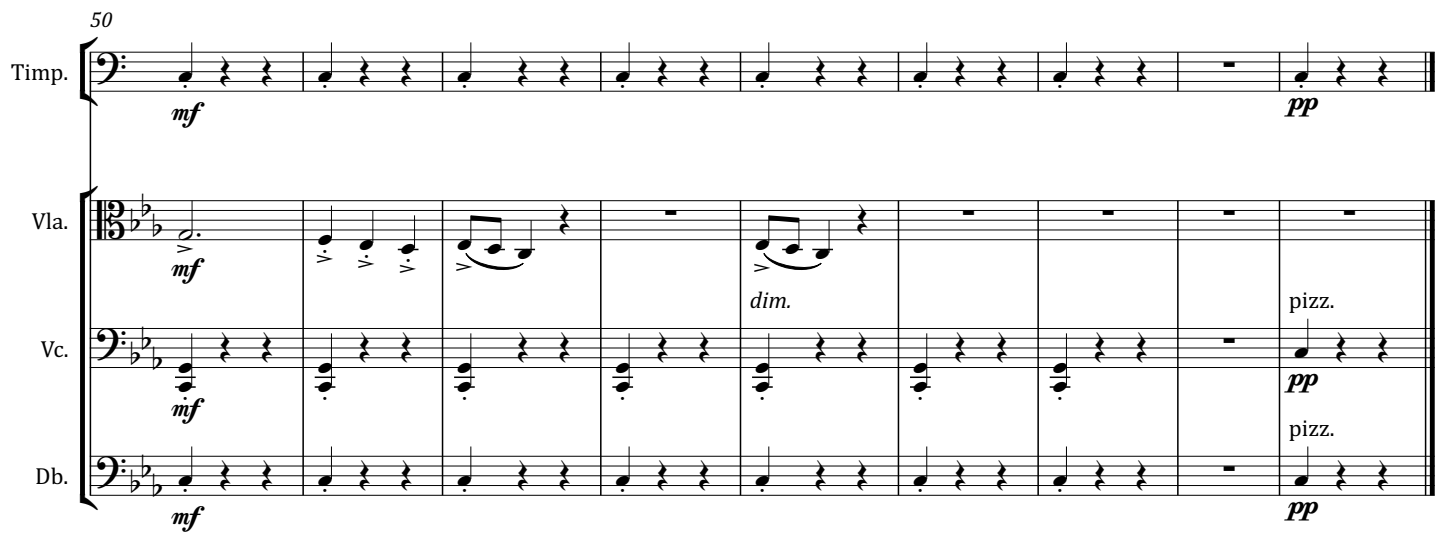


Appendix III

\section{Rewi's Last Stand}

Cue 21a 'Haka of Defiance'

Alfred Hill
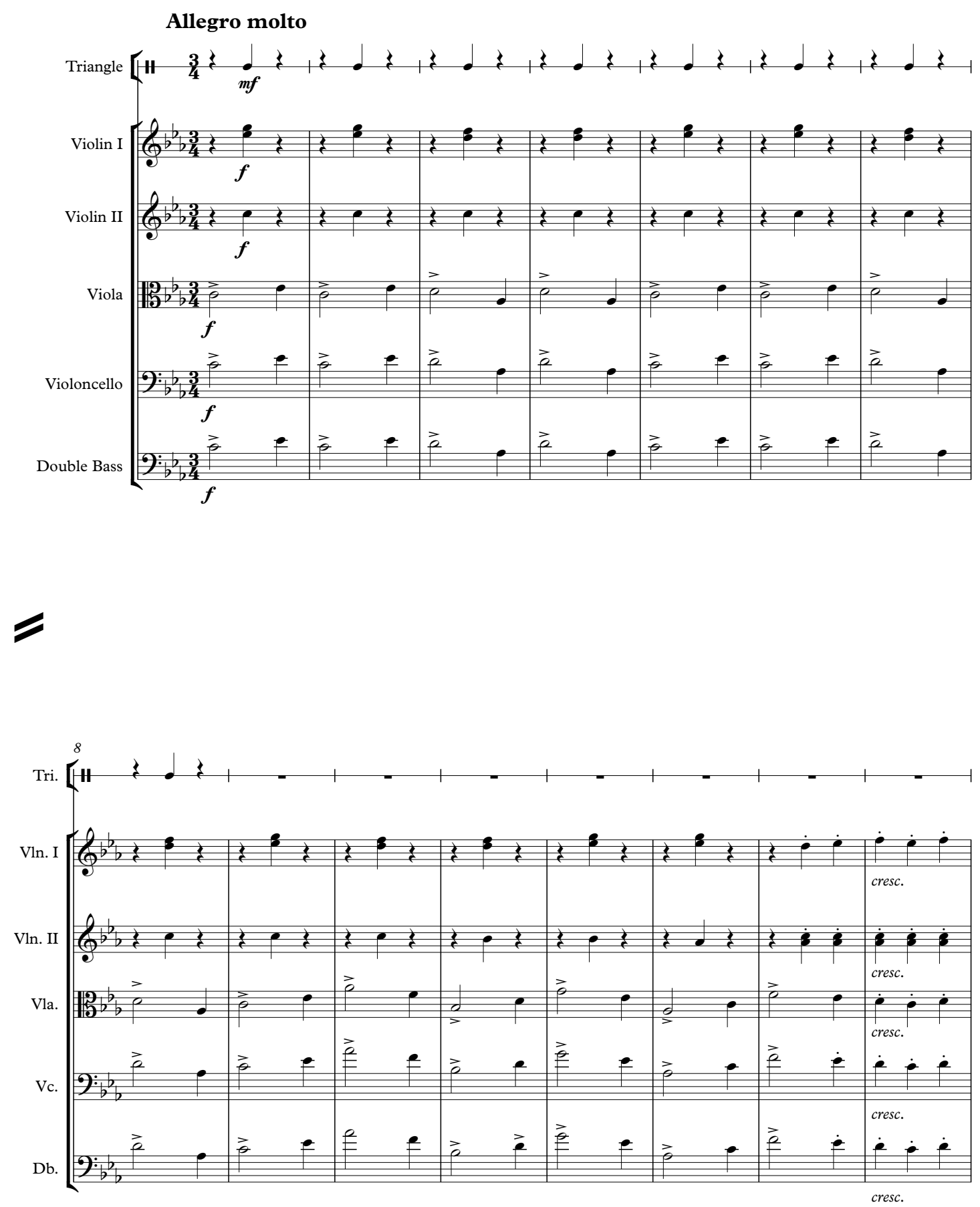


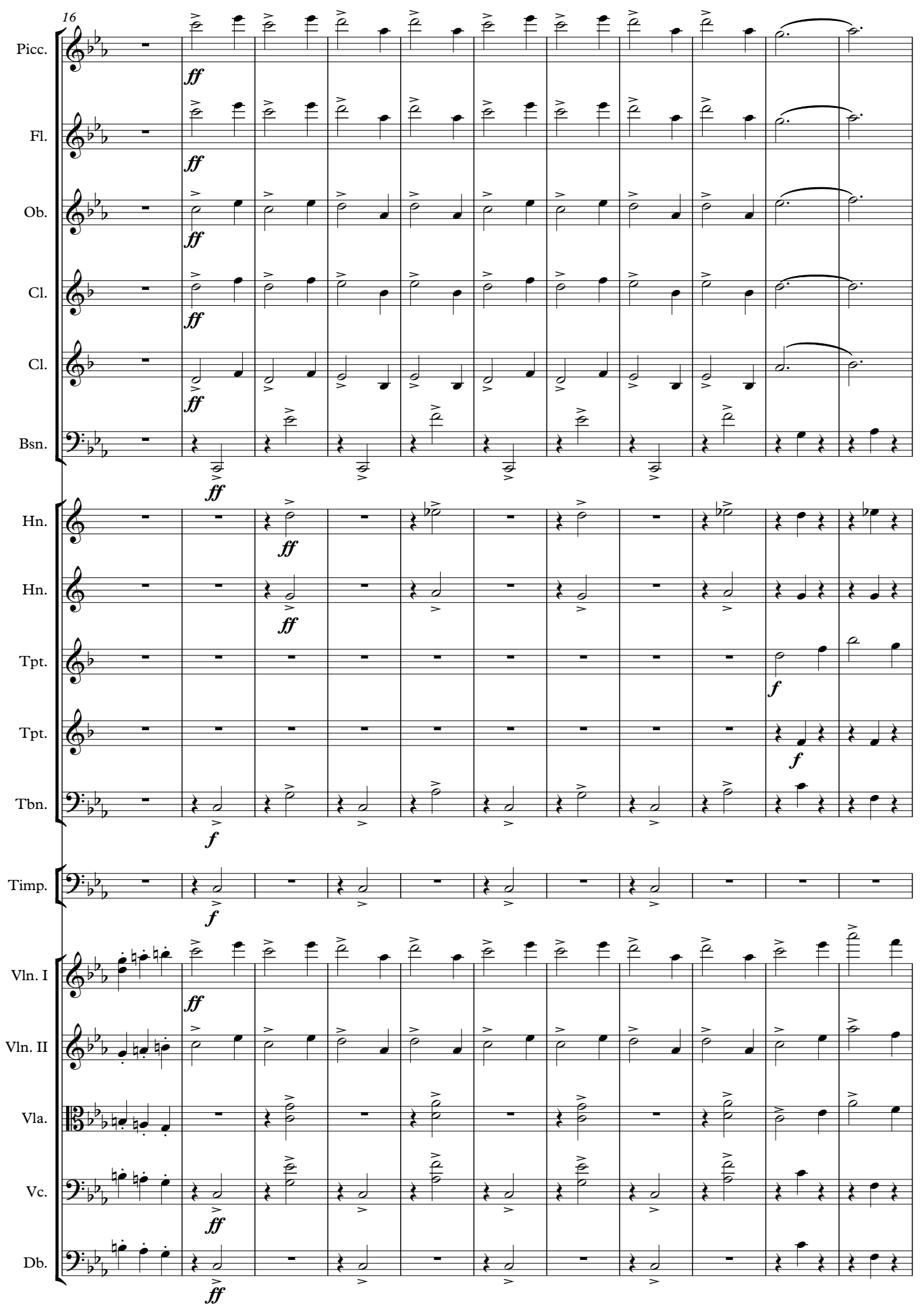




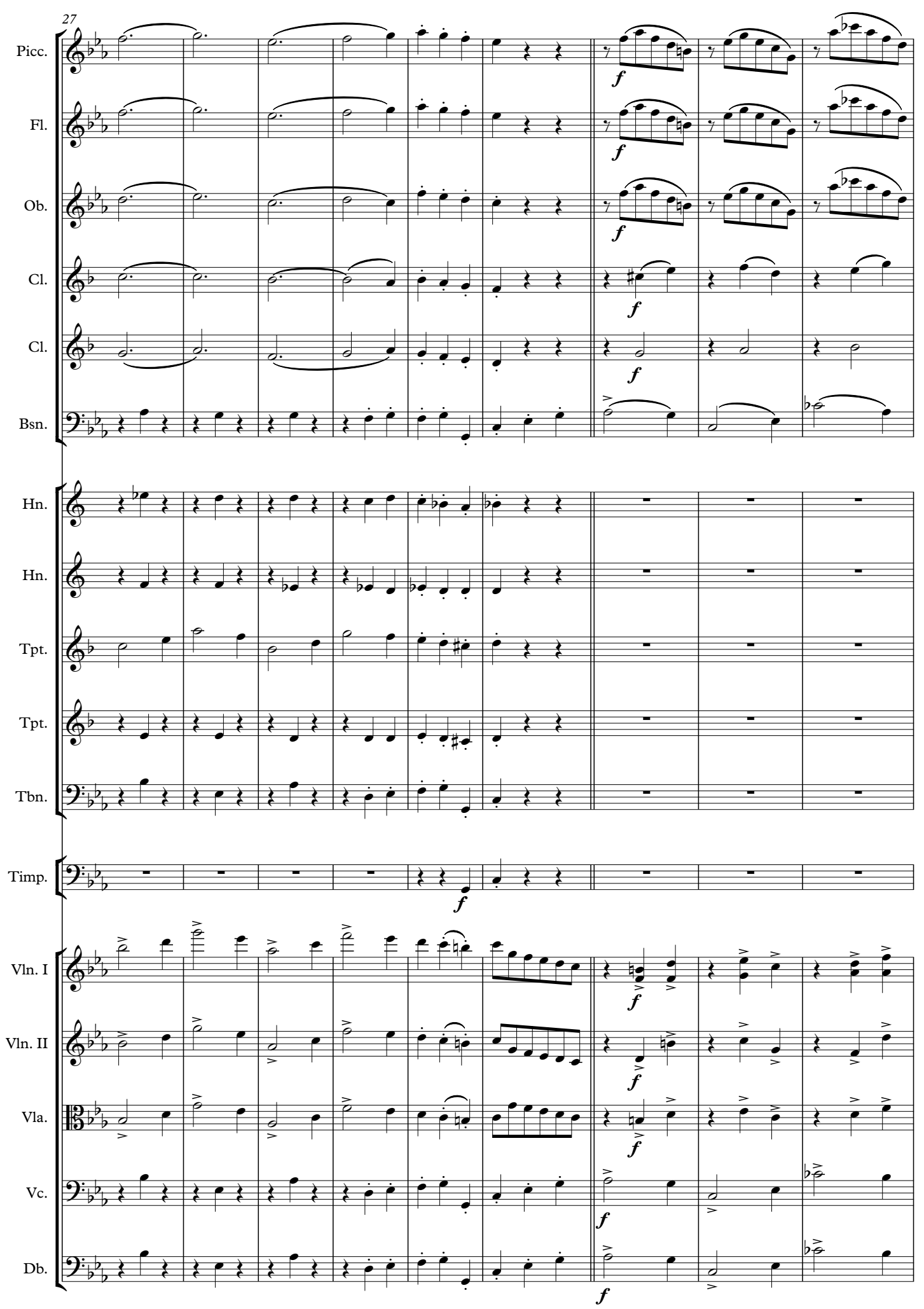



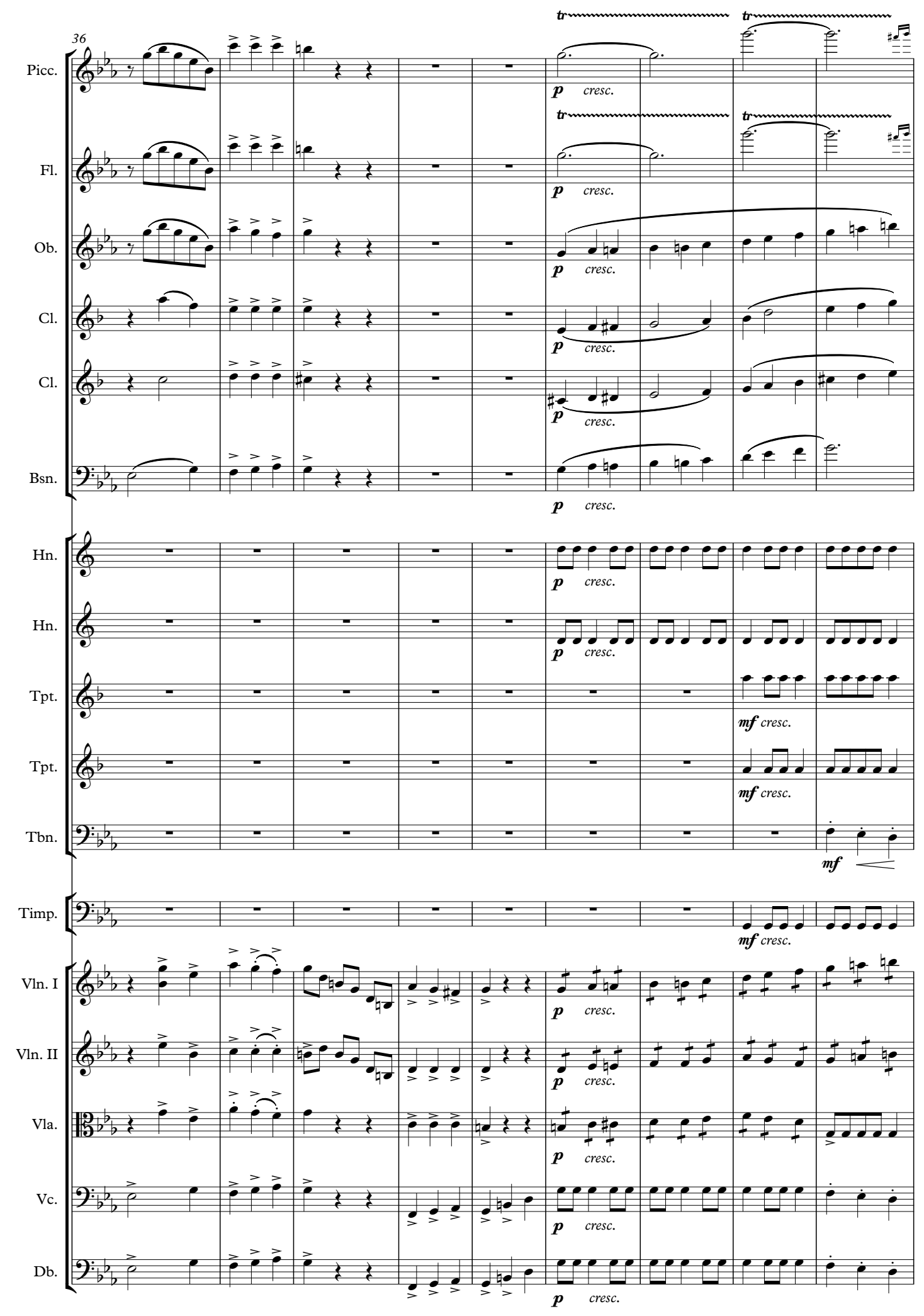

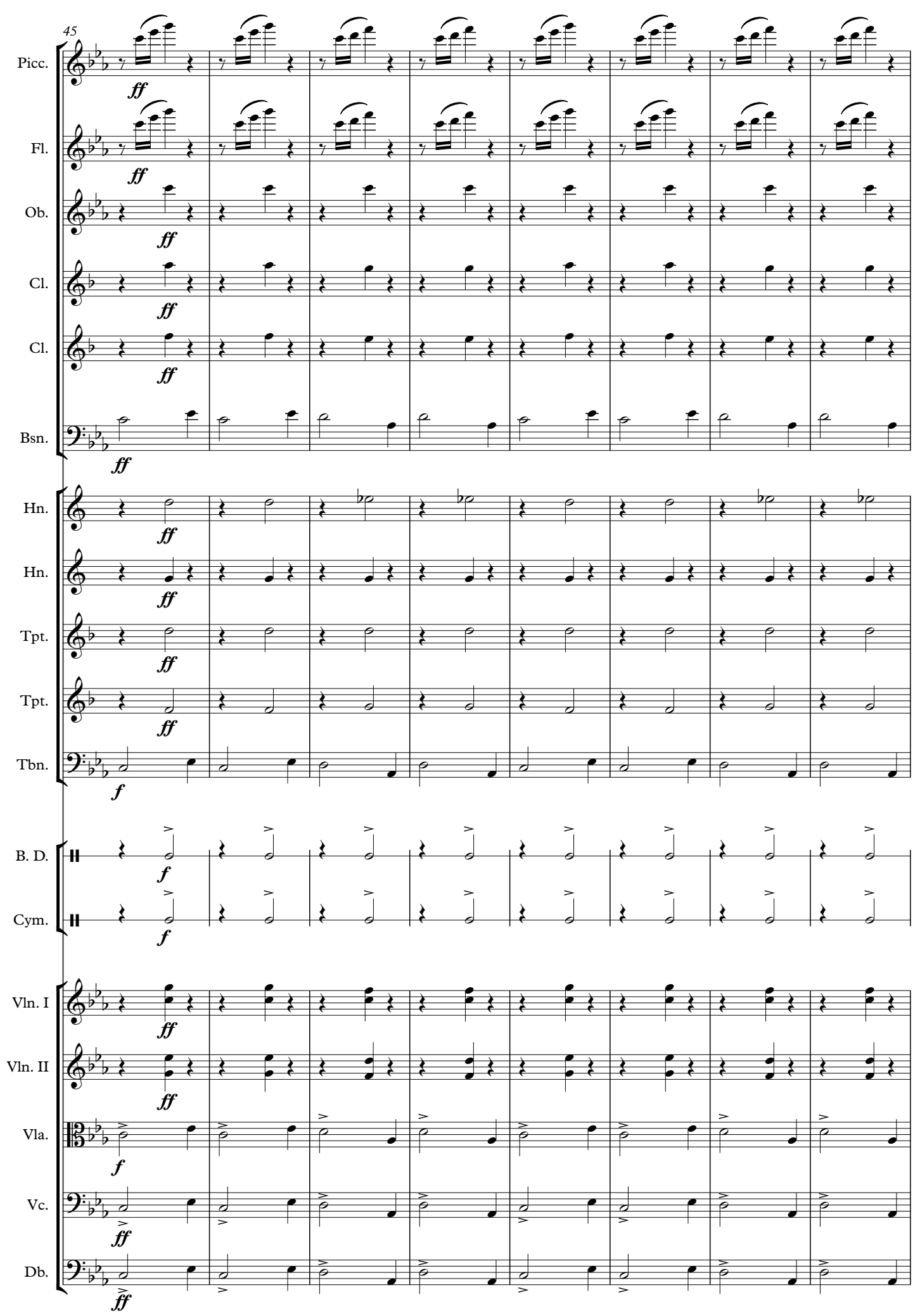

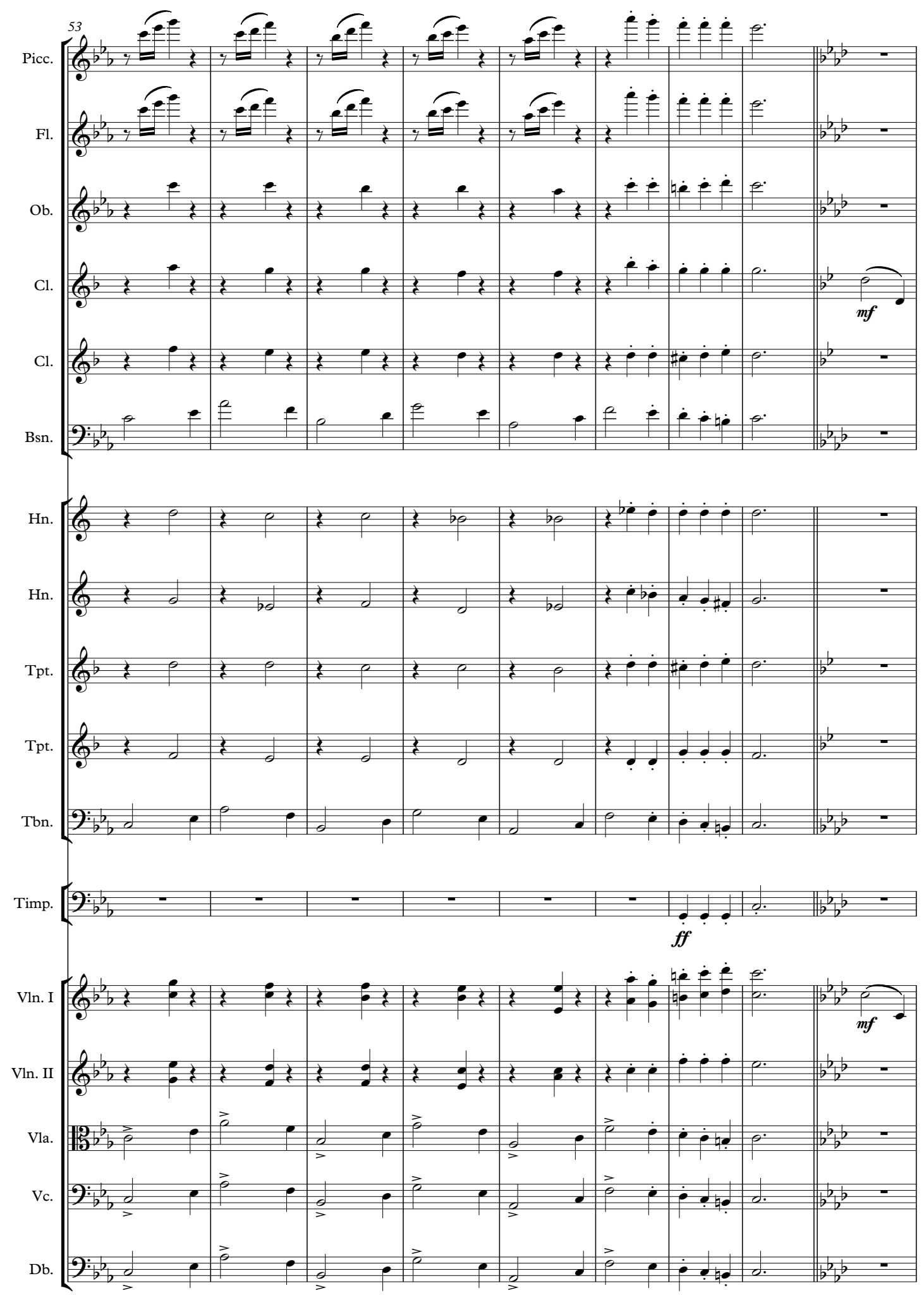


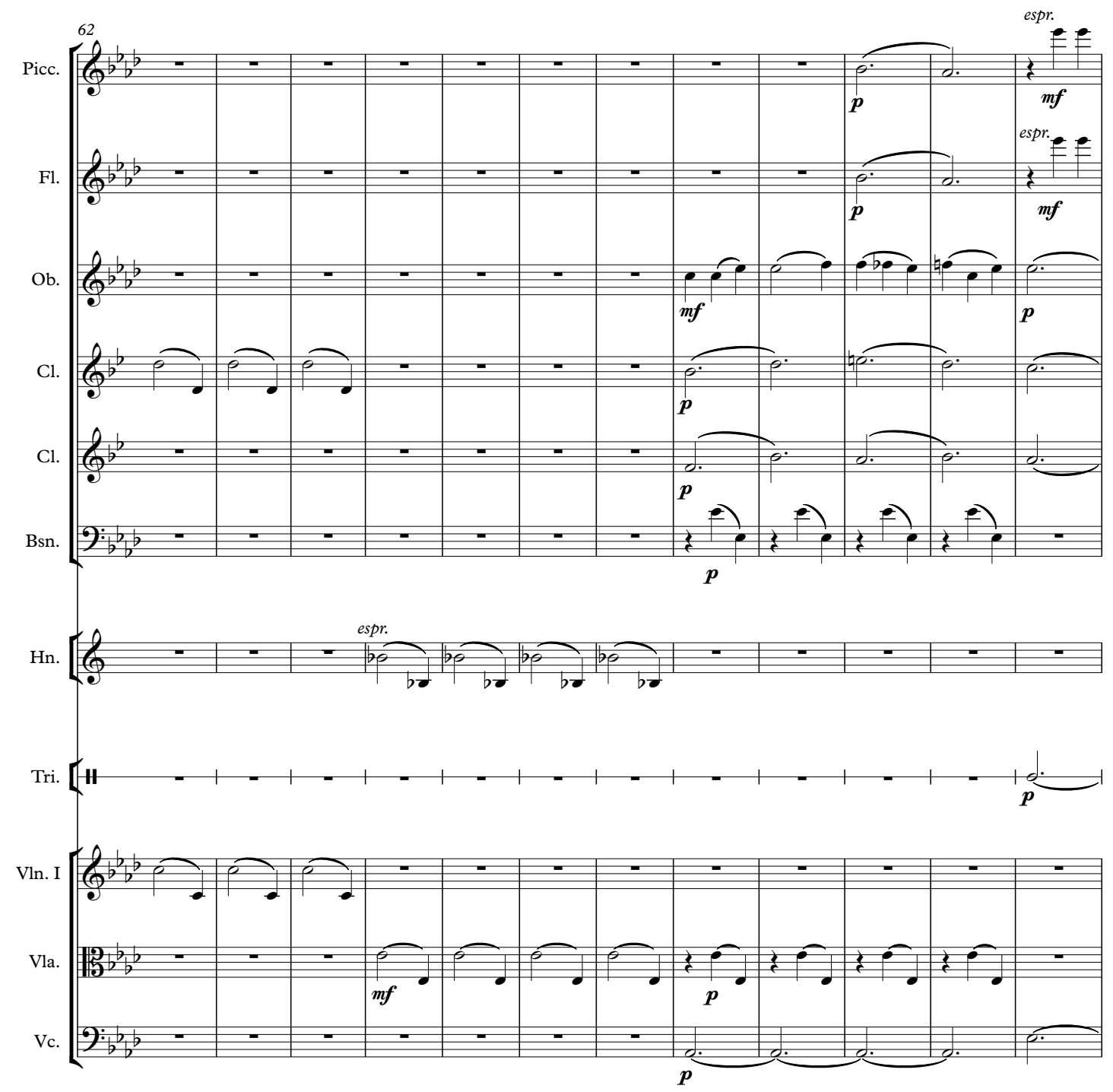



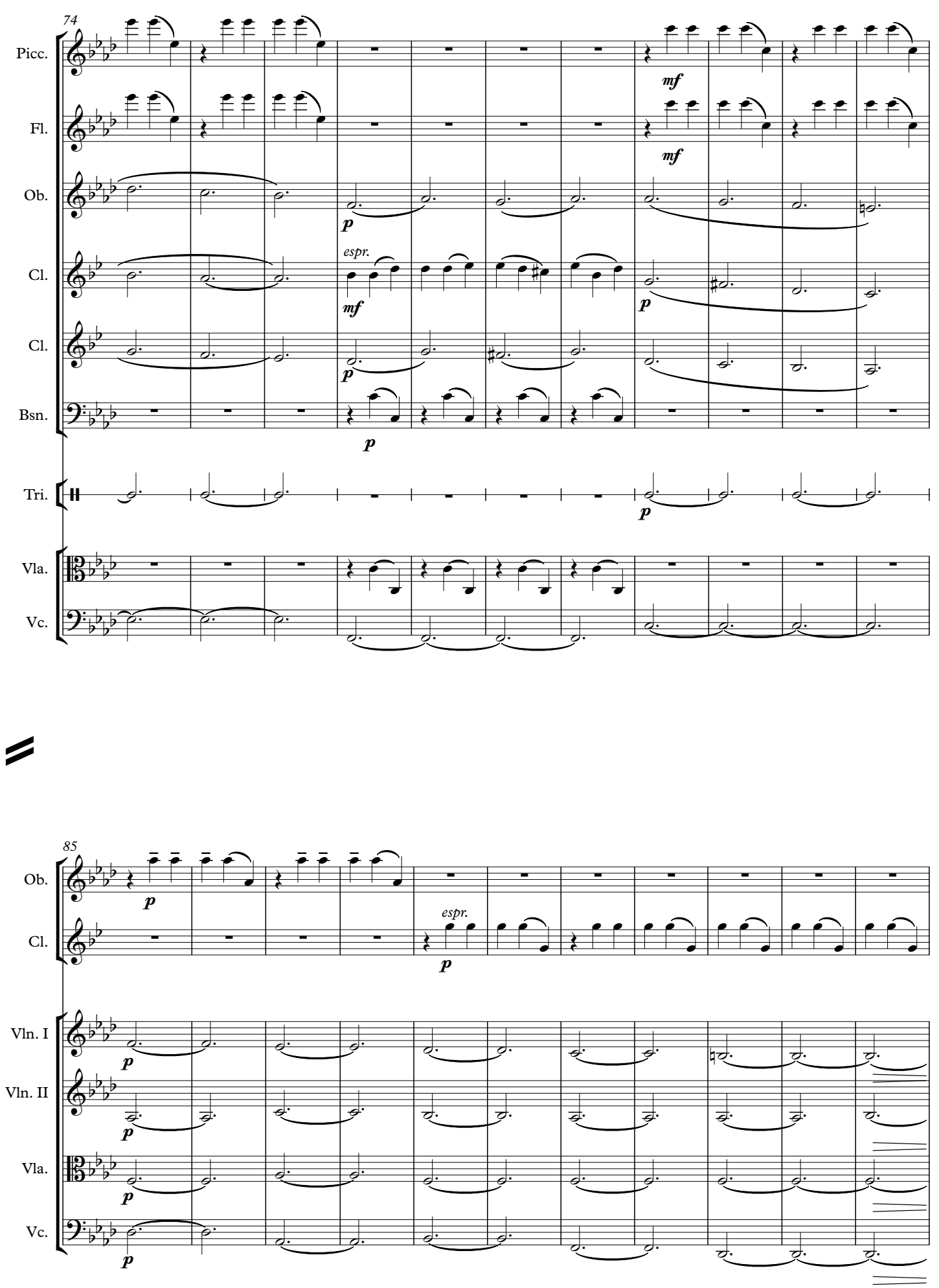


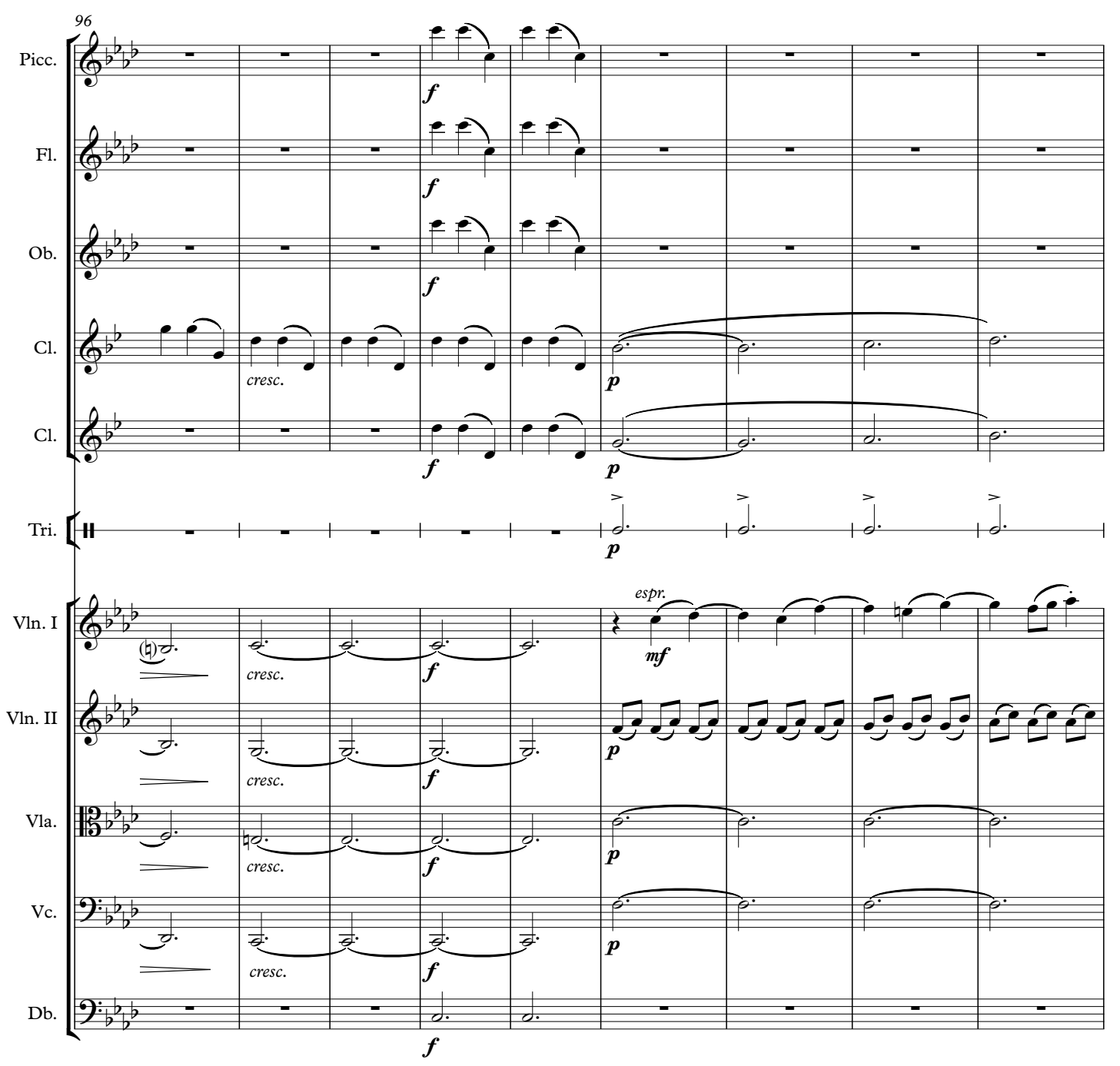



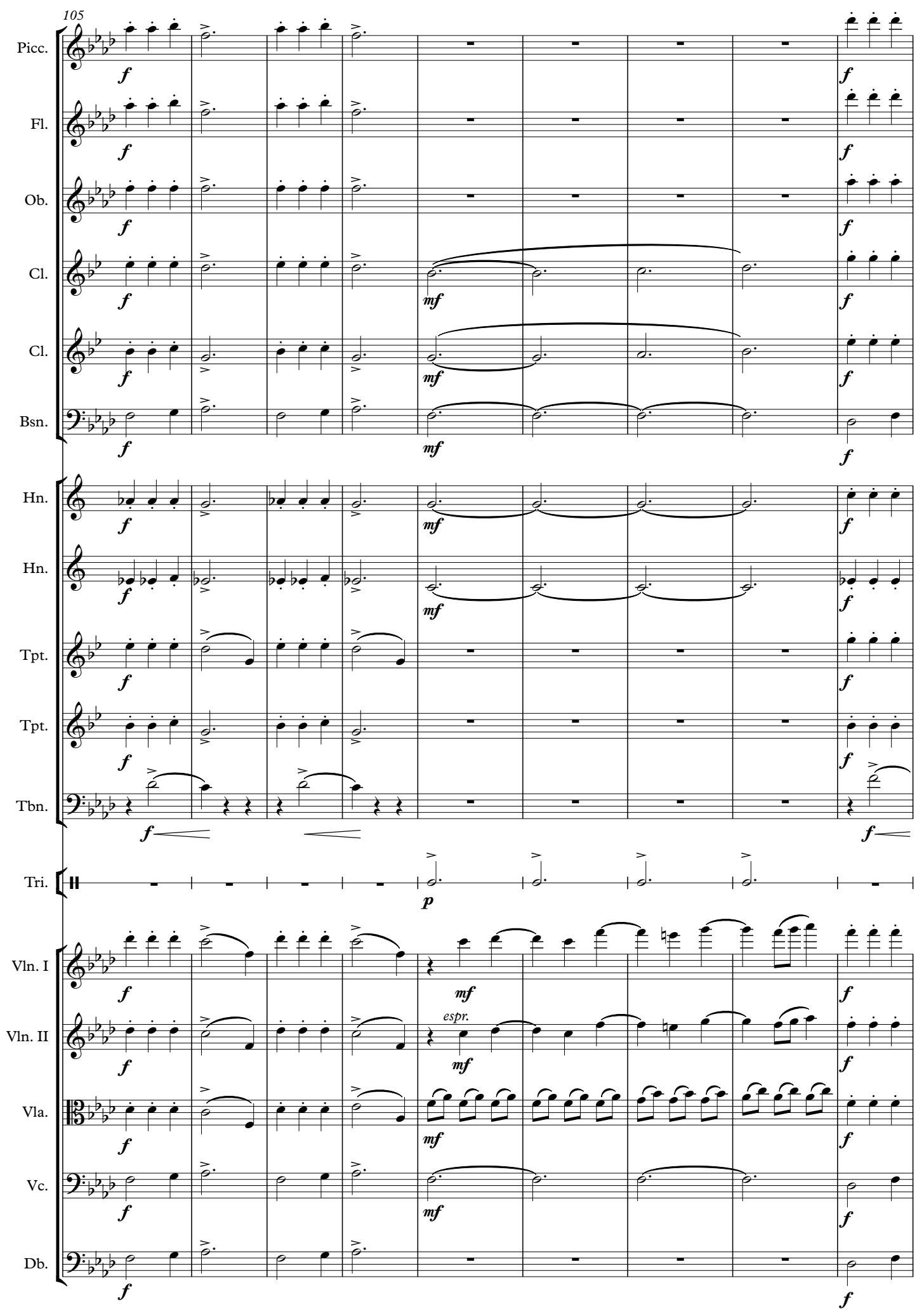

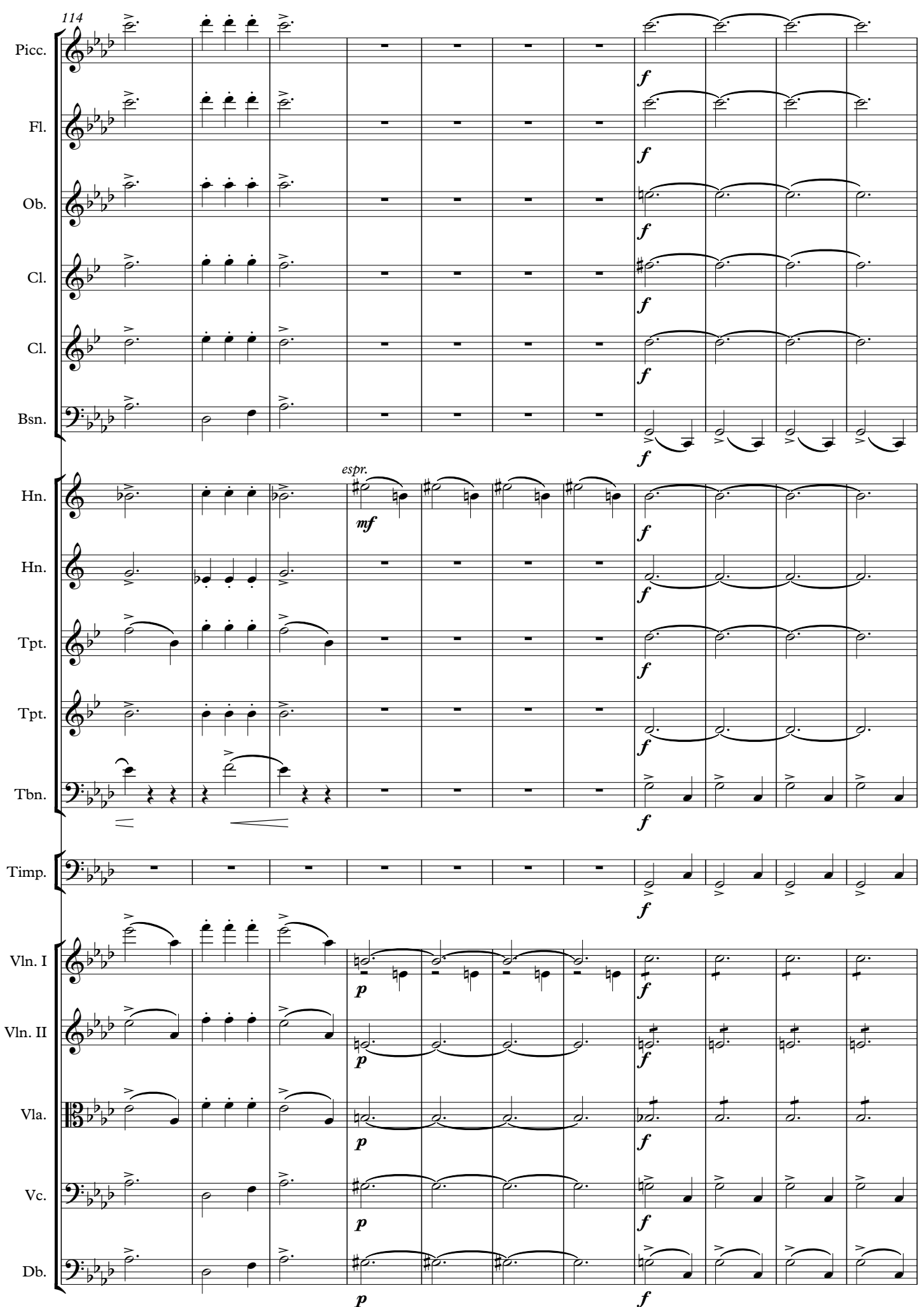

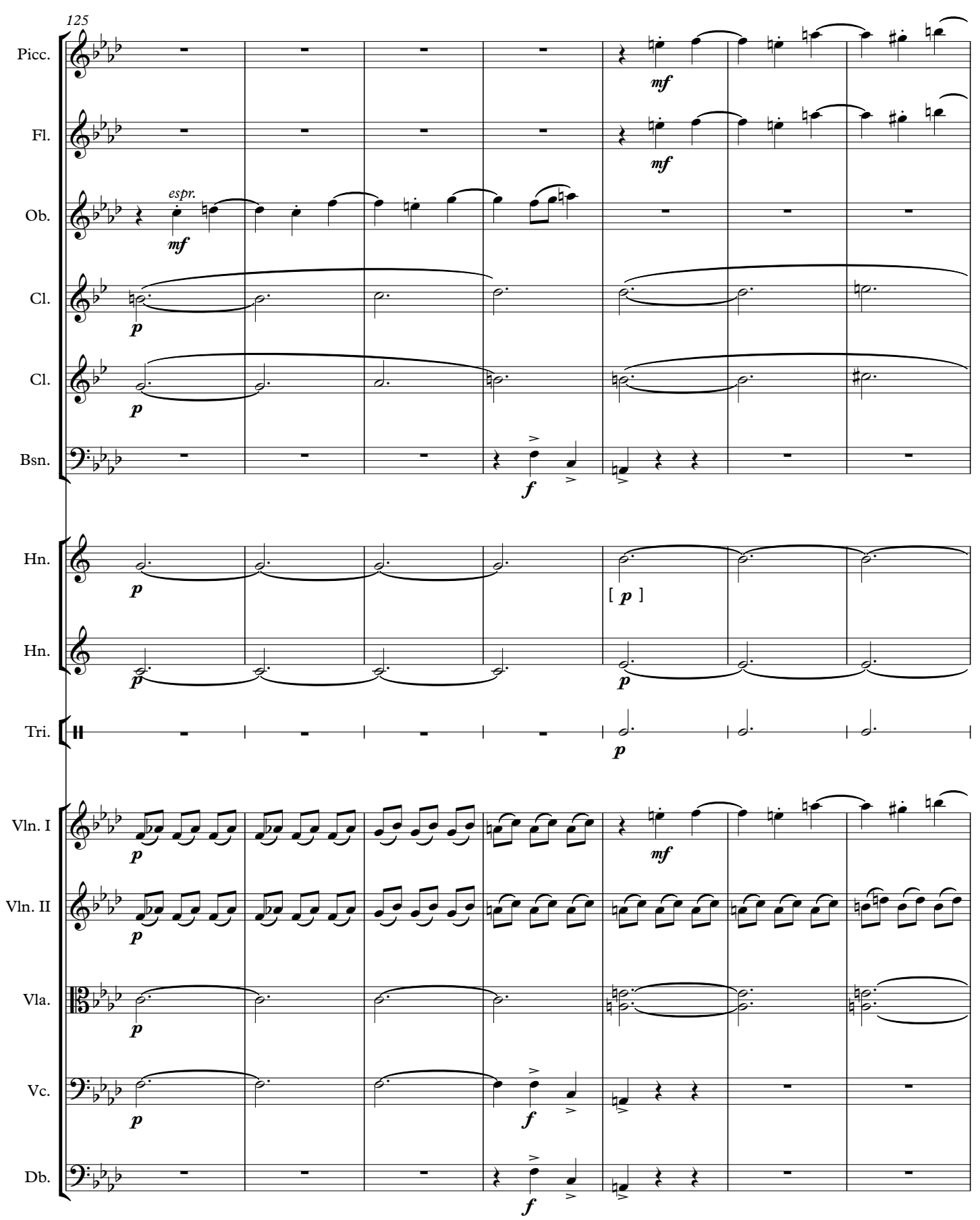

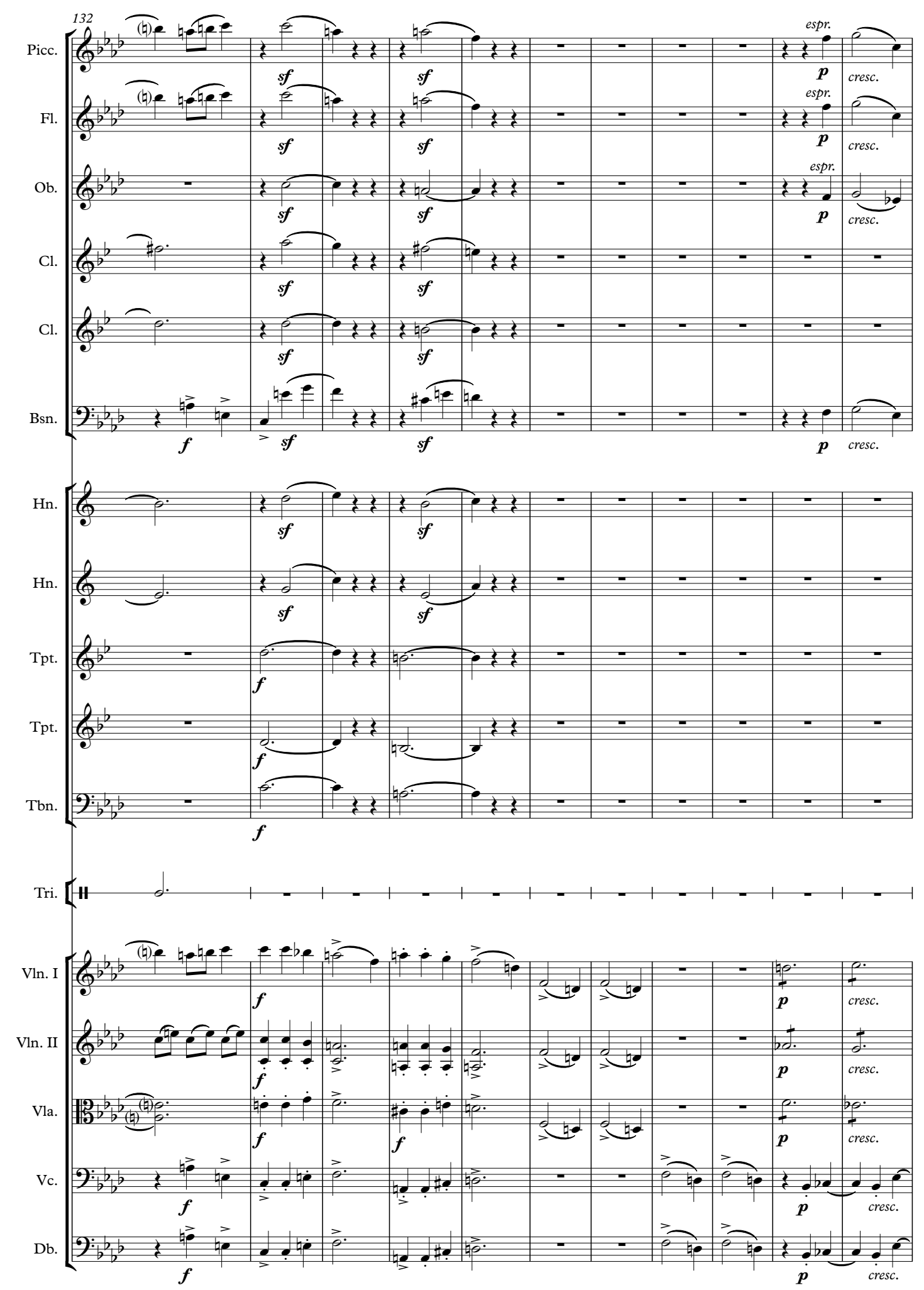

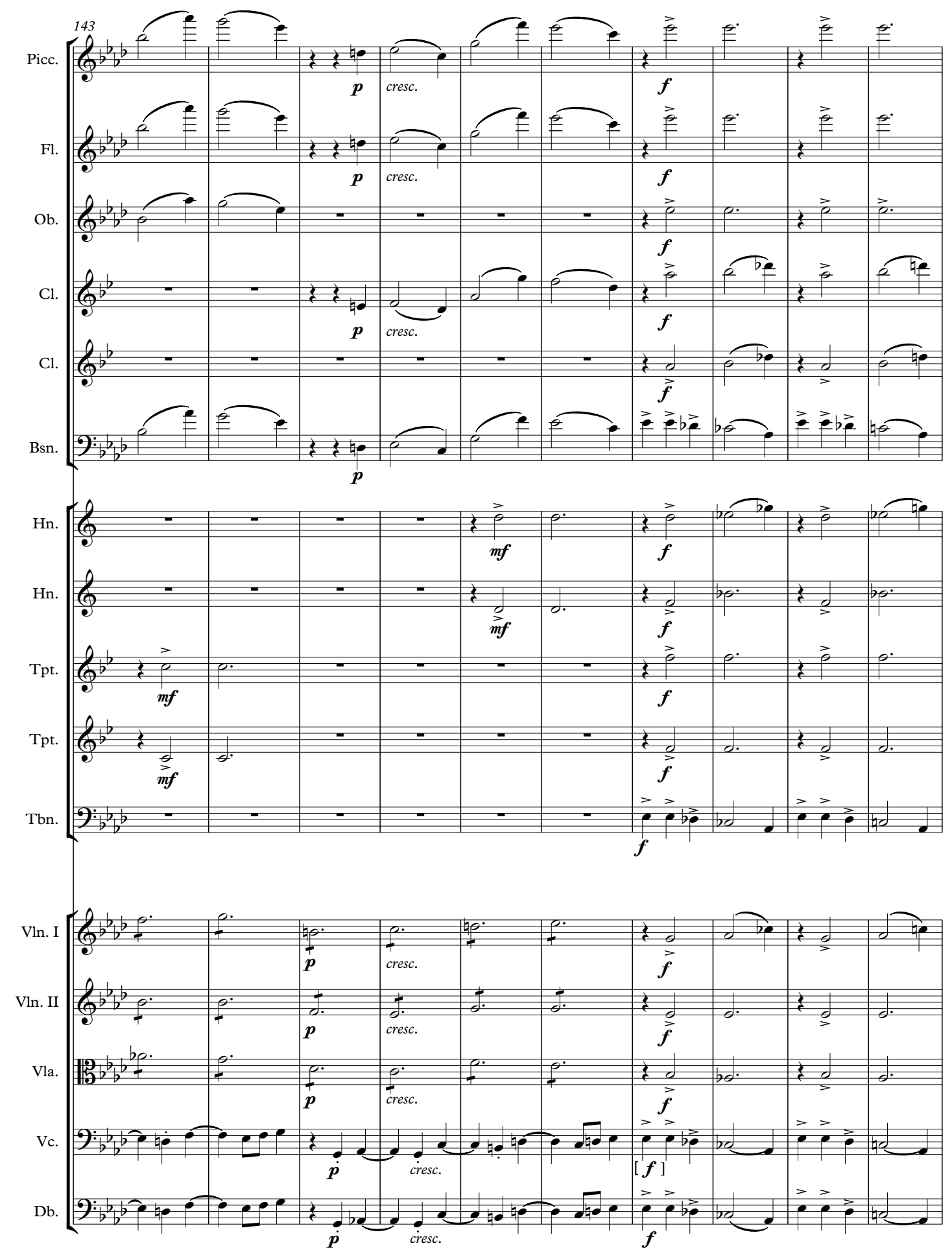
rall. - -
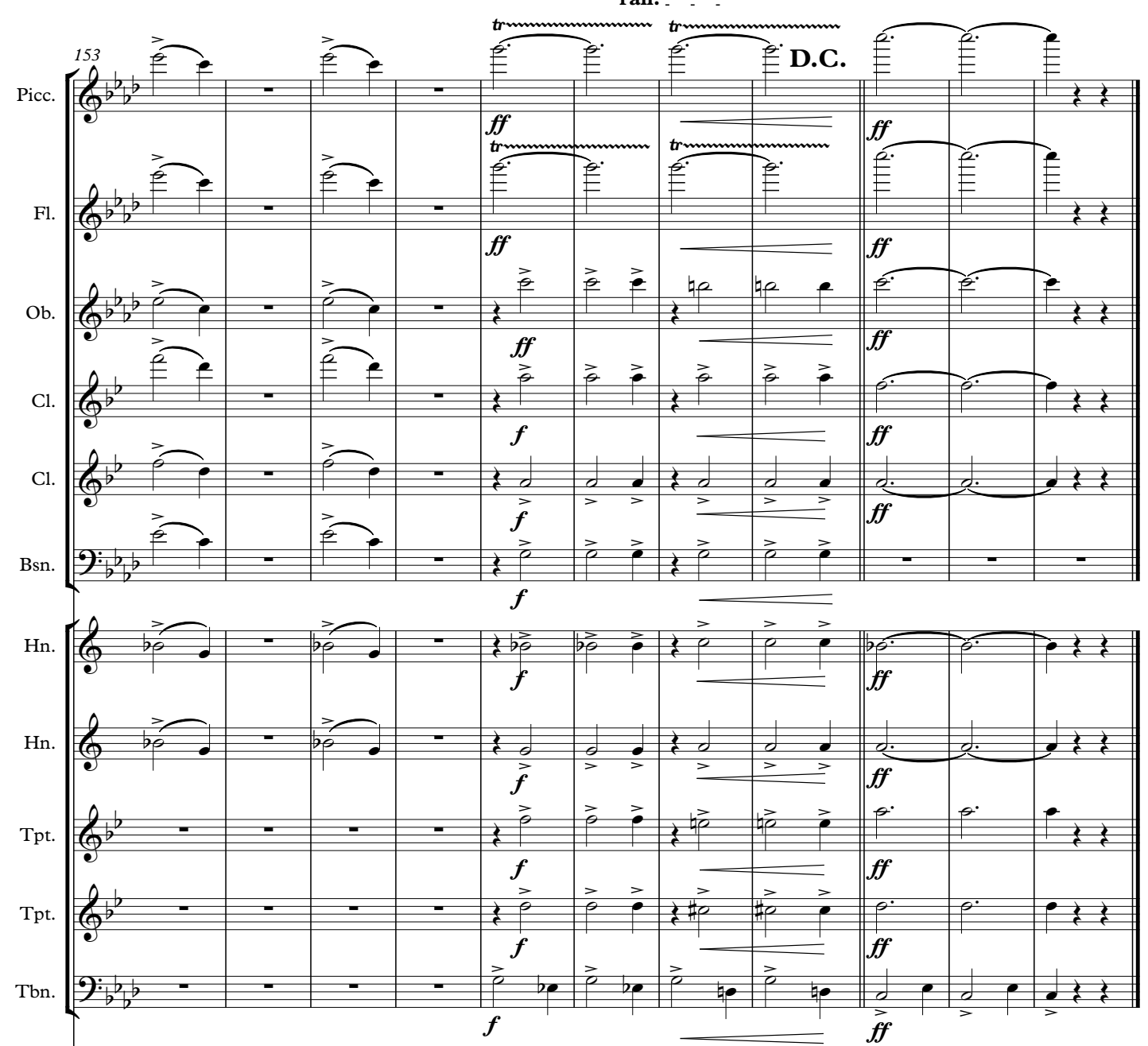

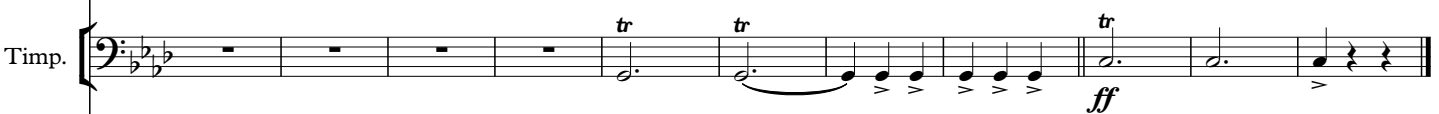

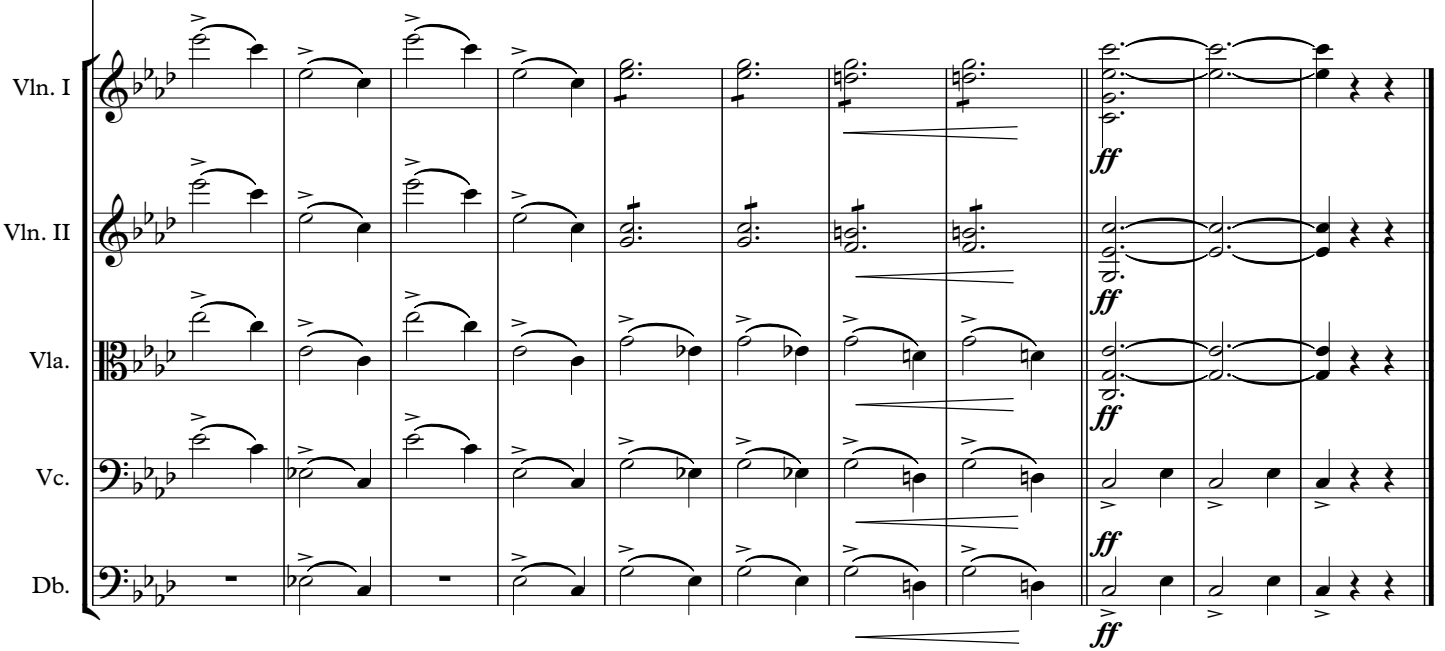


Appendix IV

\section{Rewi's Last Stand}

Cue 29 'Maori Defiance'

Allegro

Alfred Hill
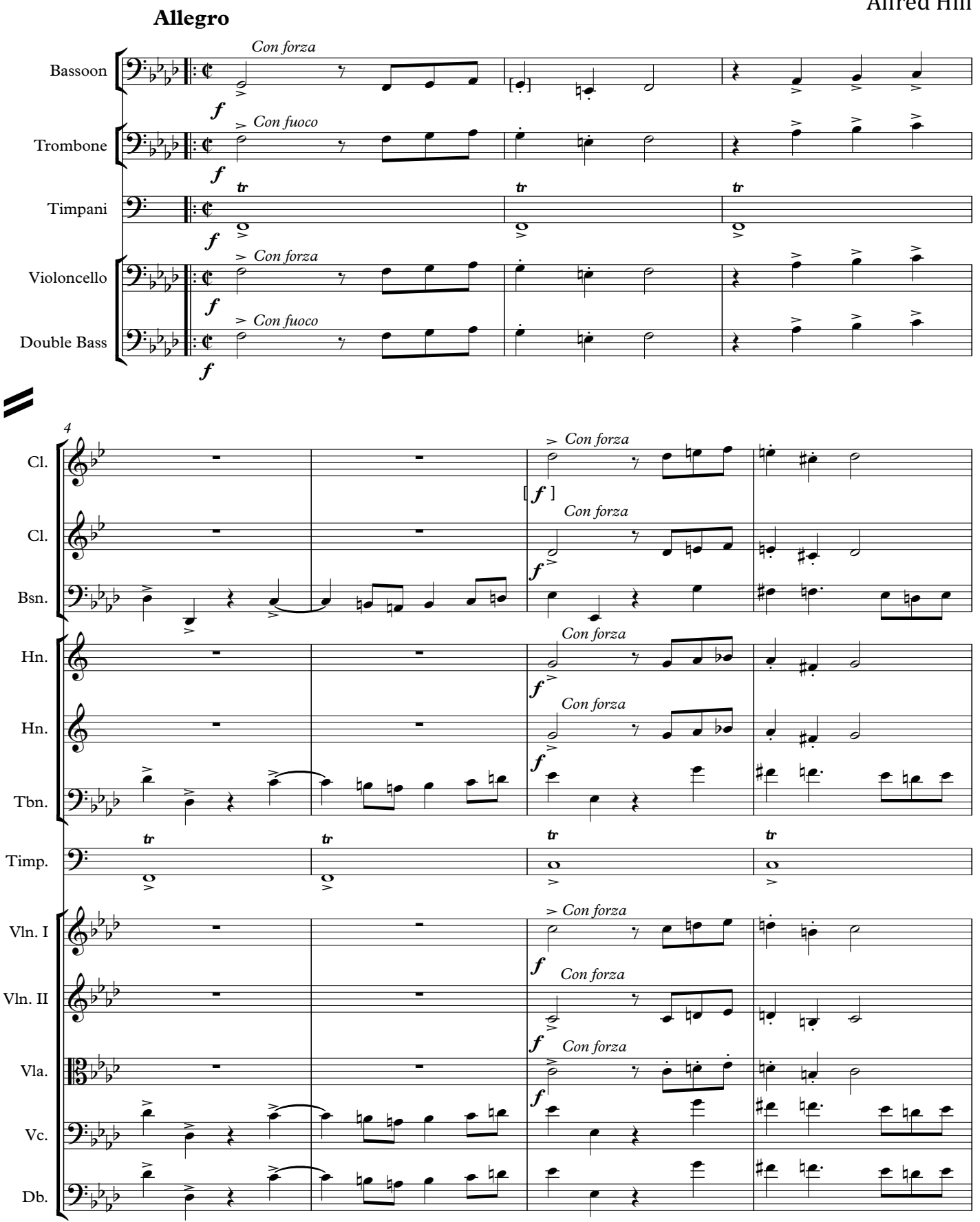

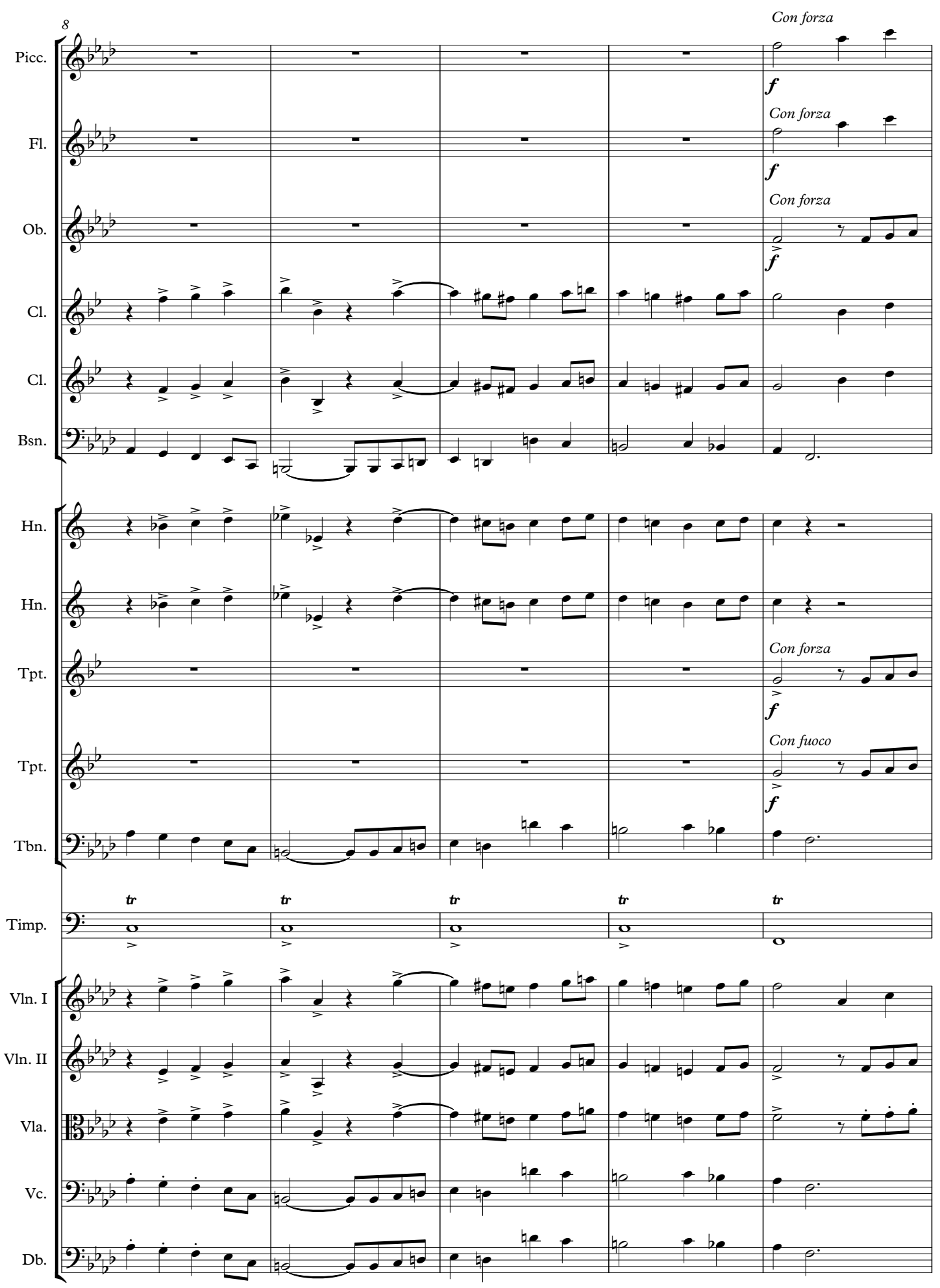


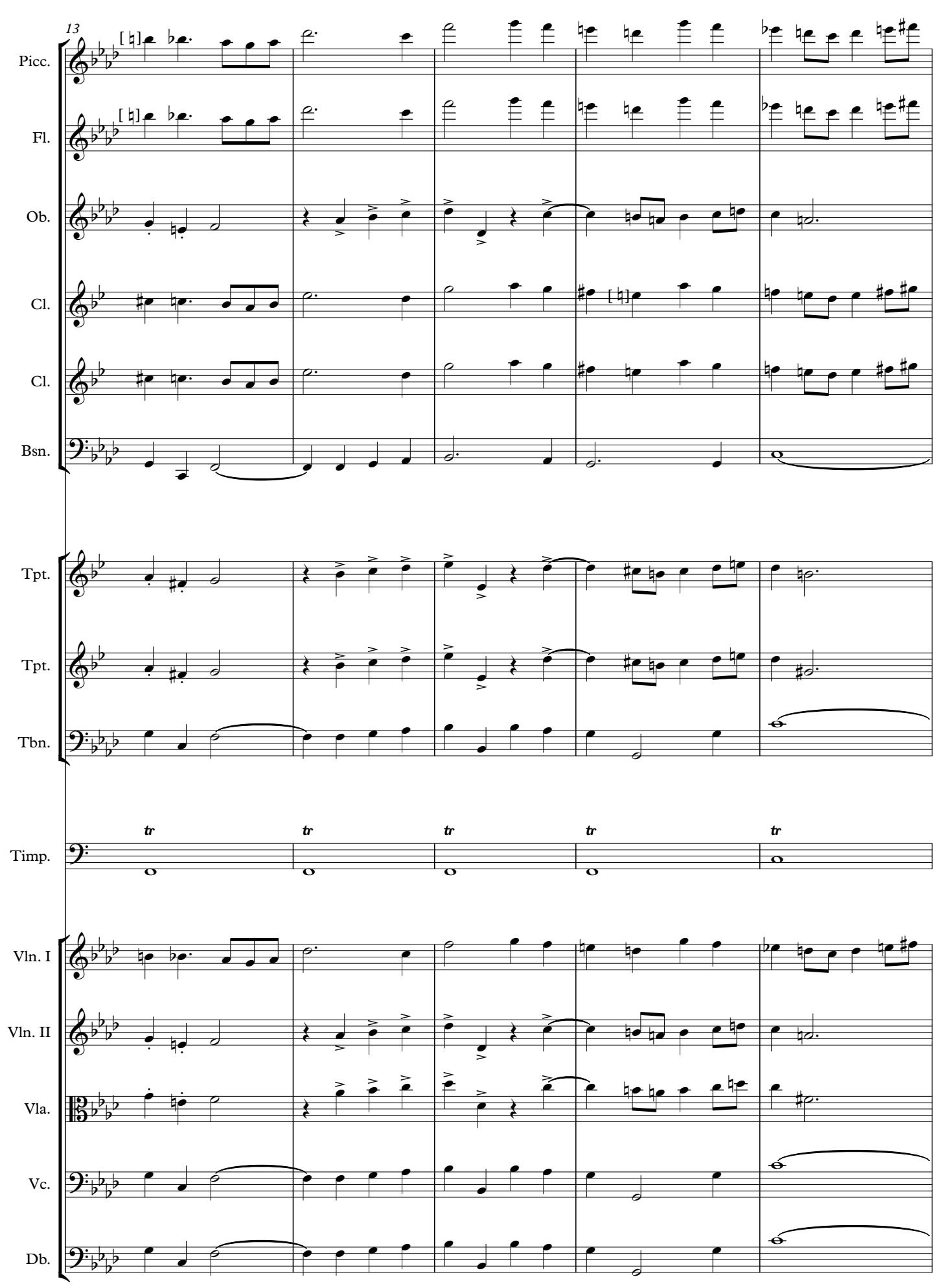




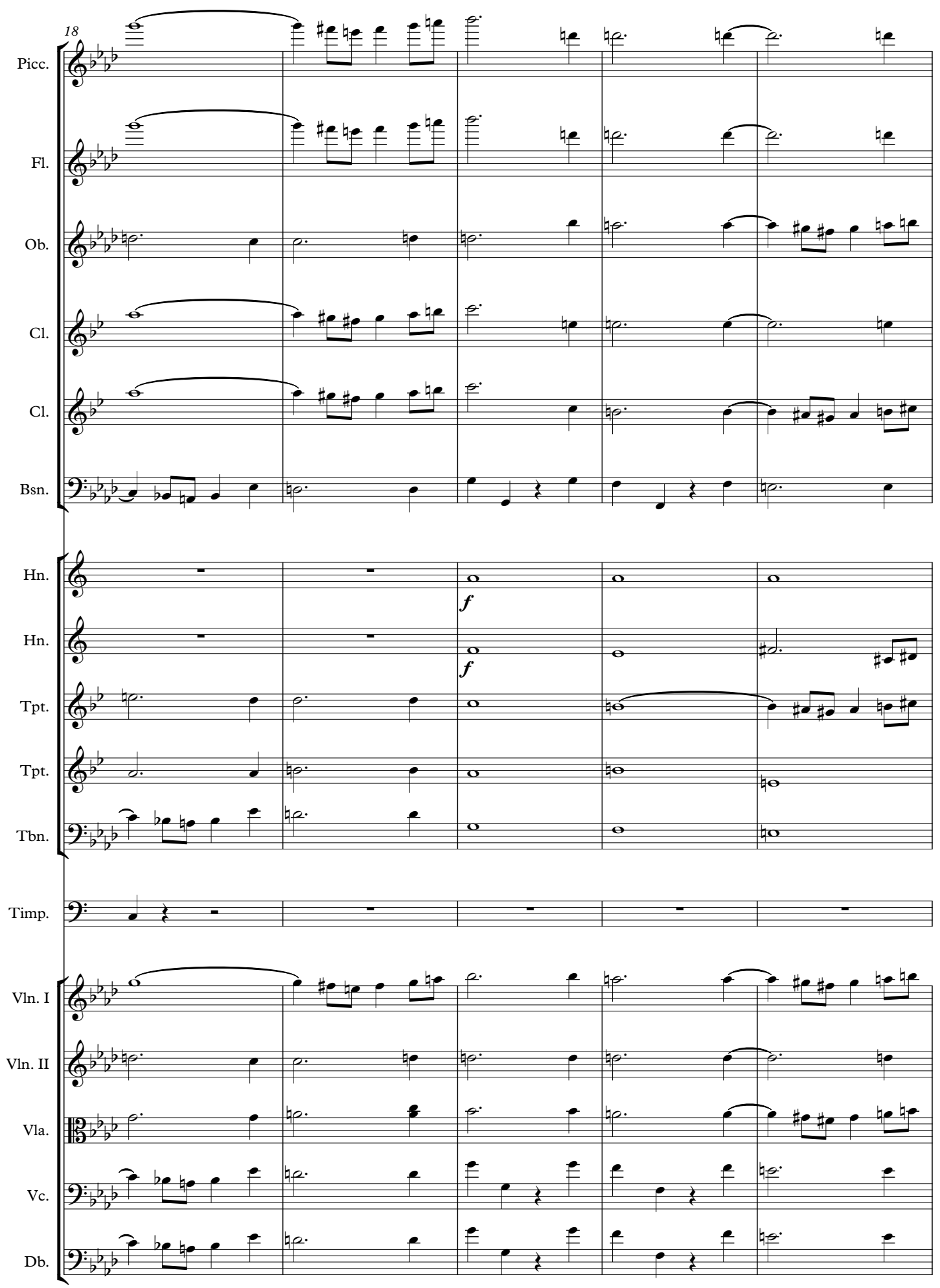




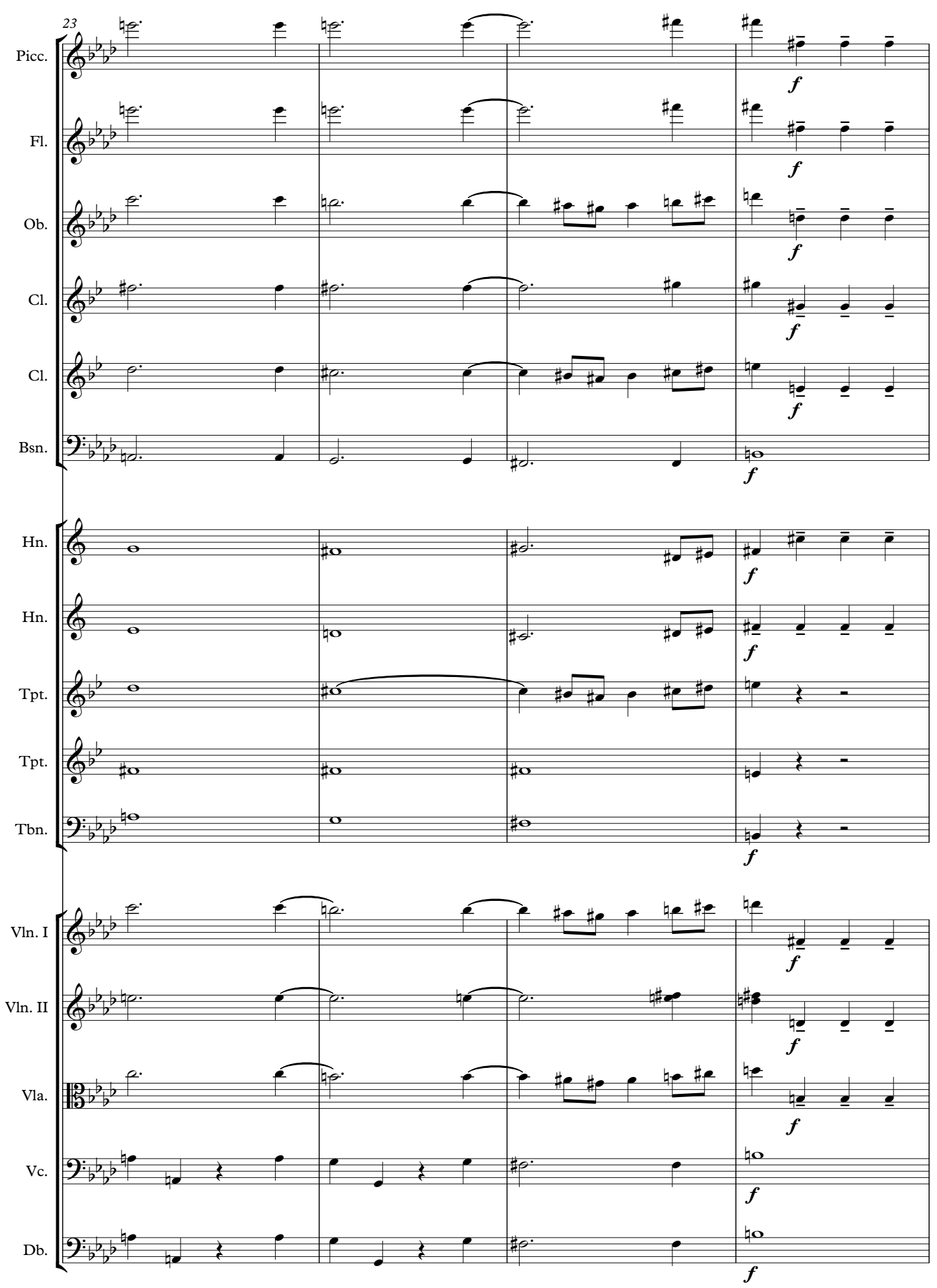




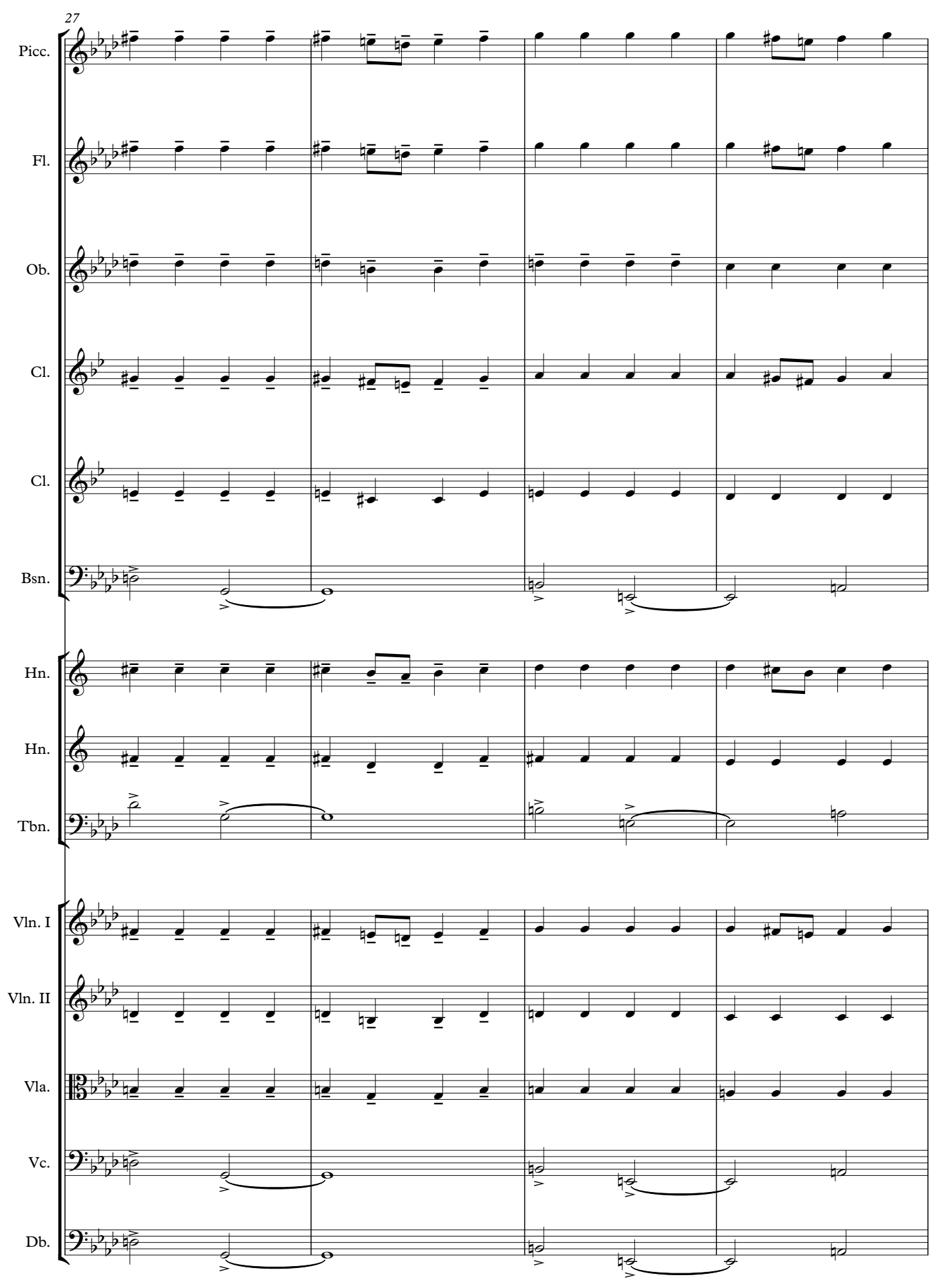



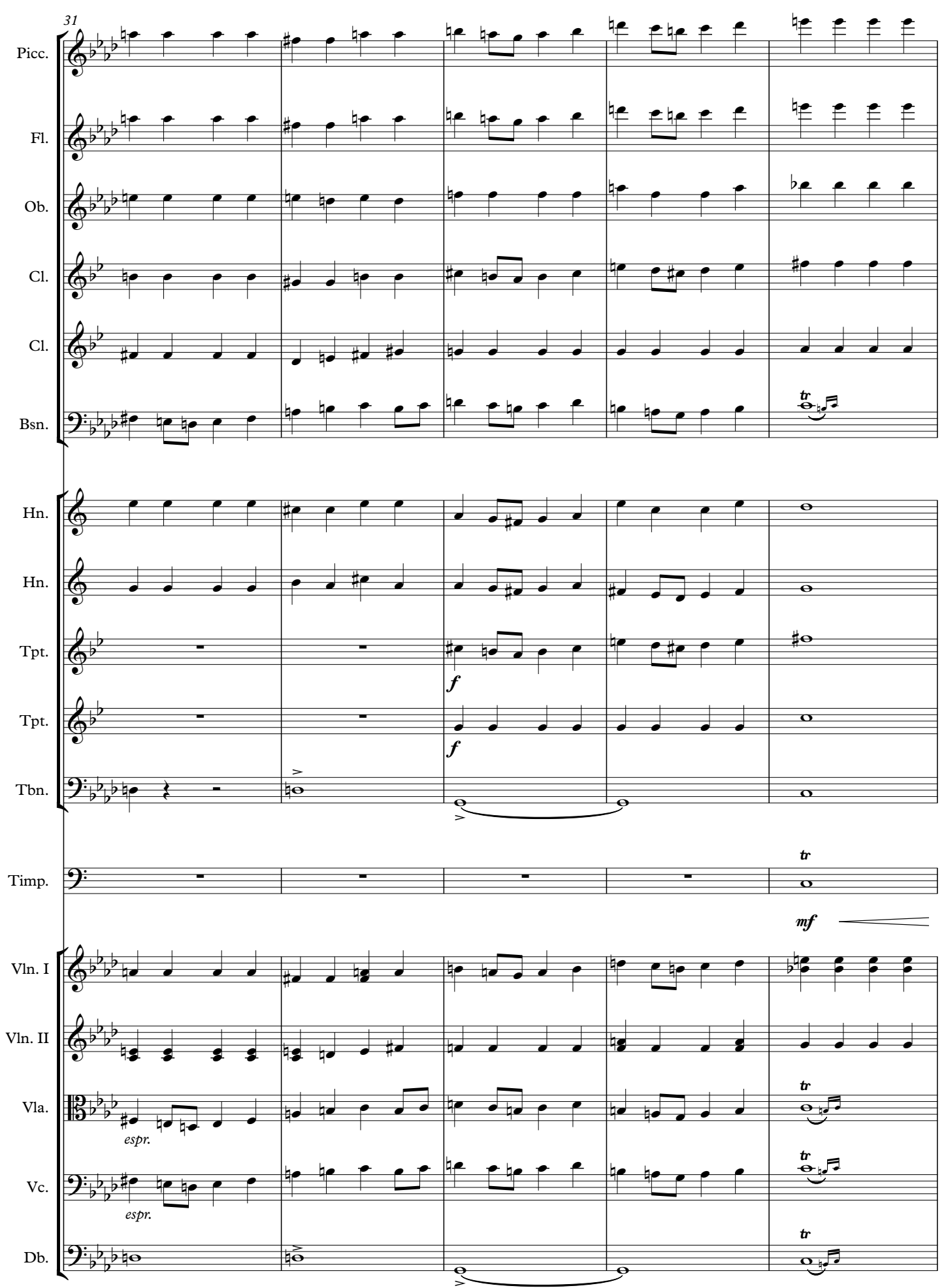


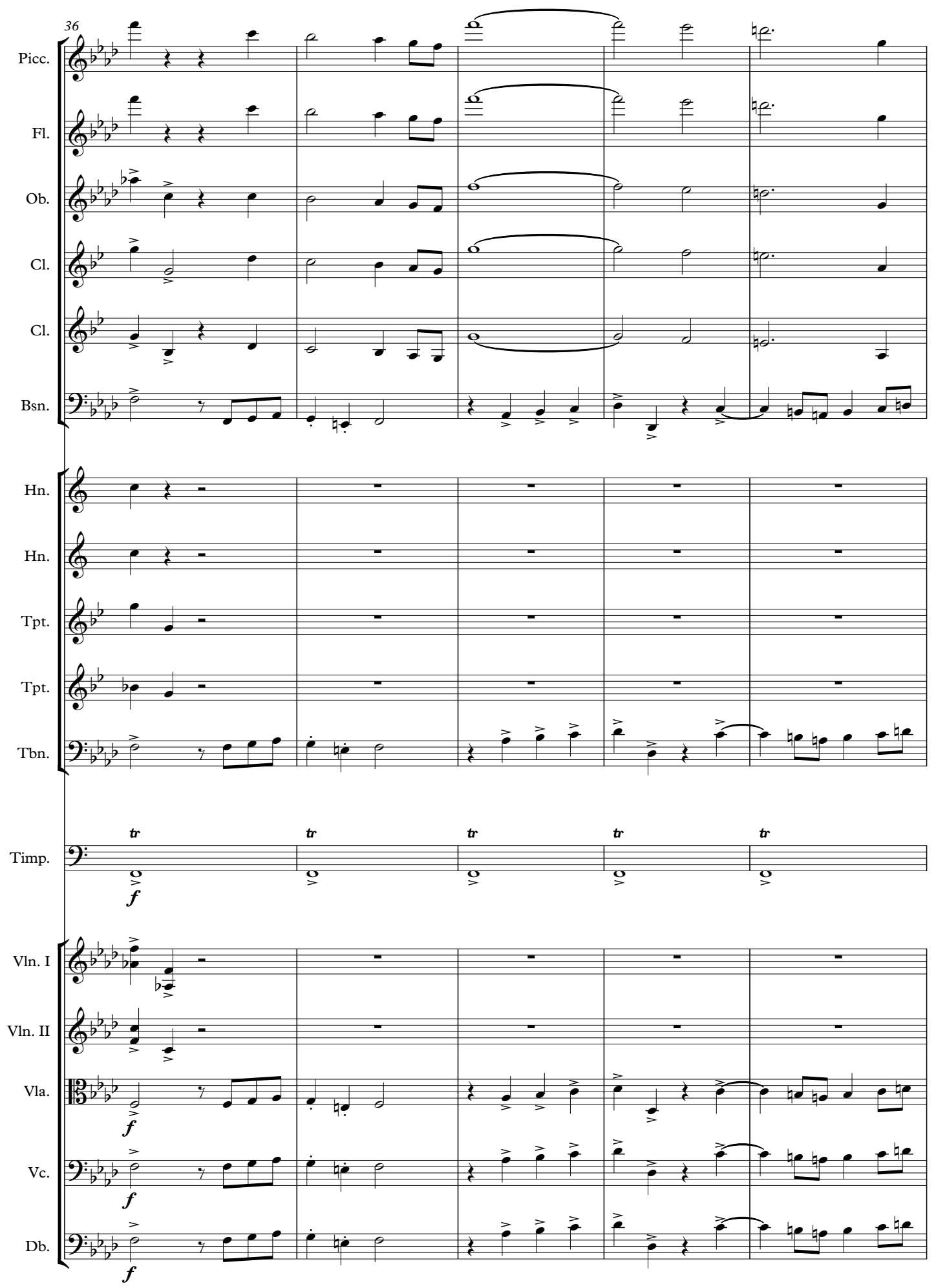




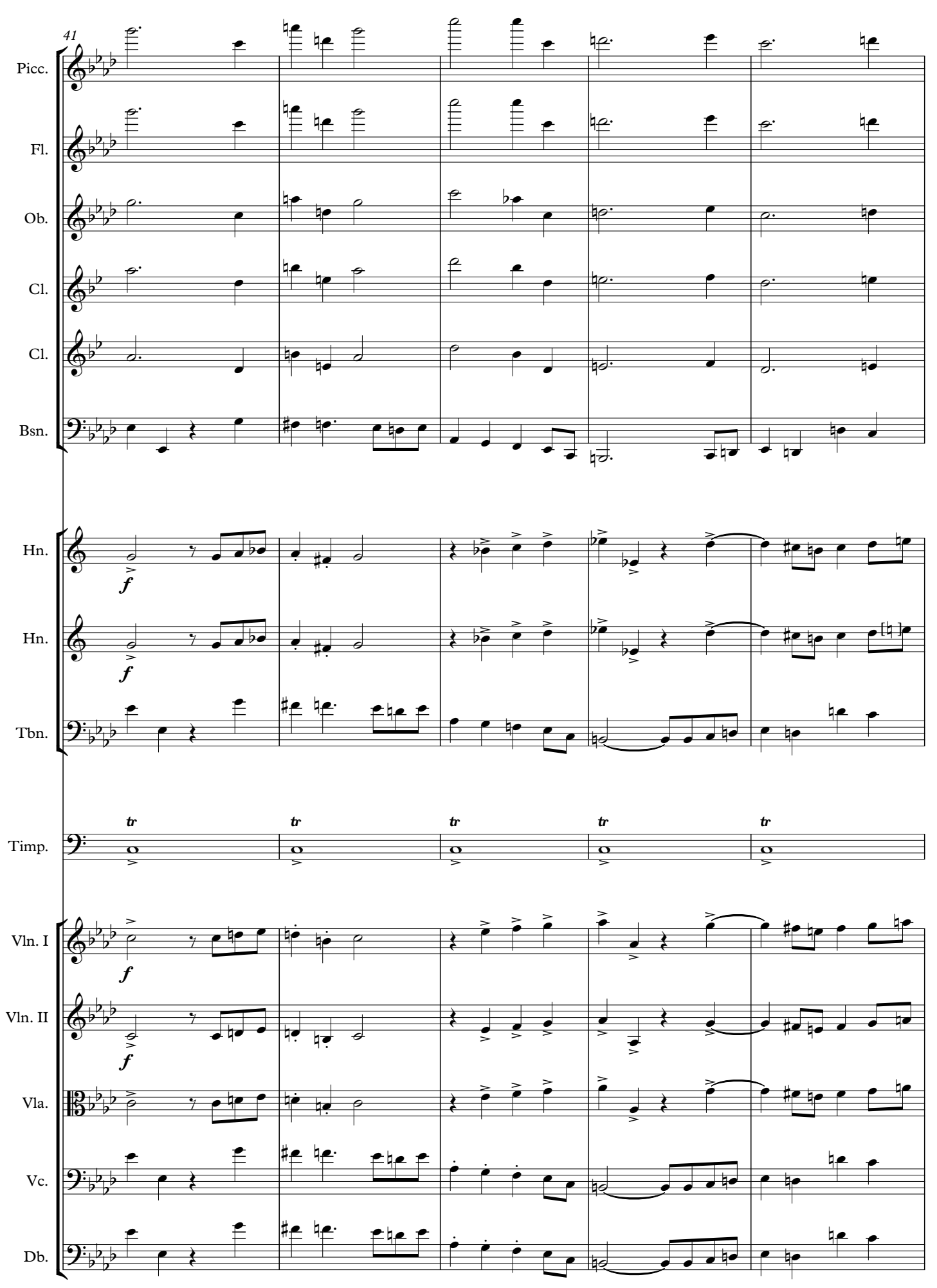



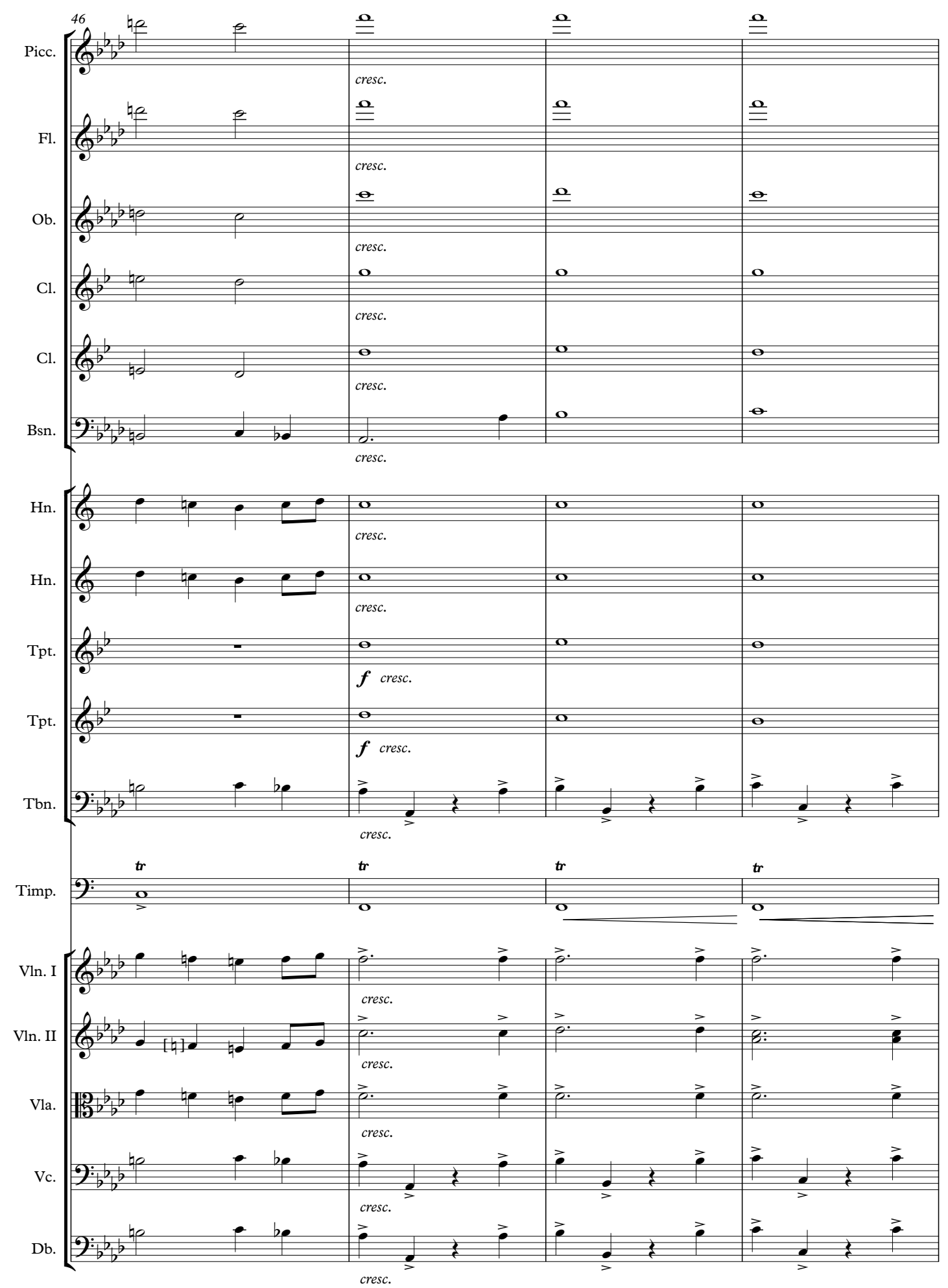

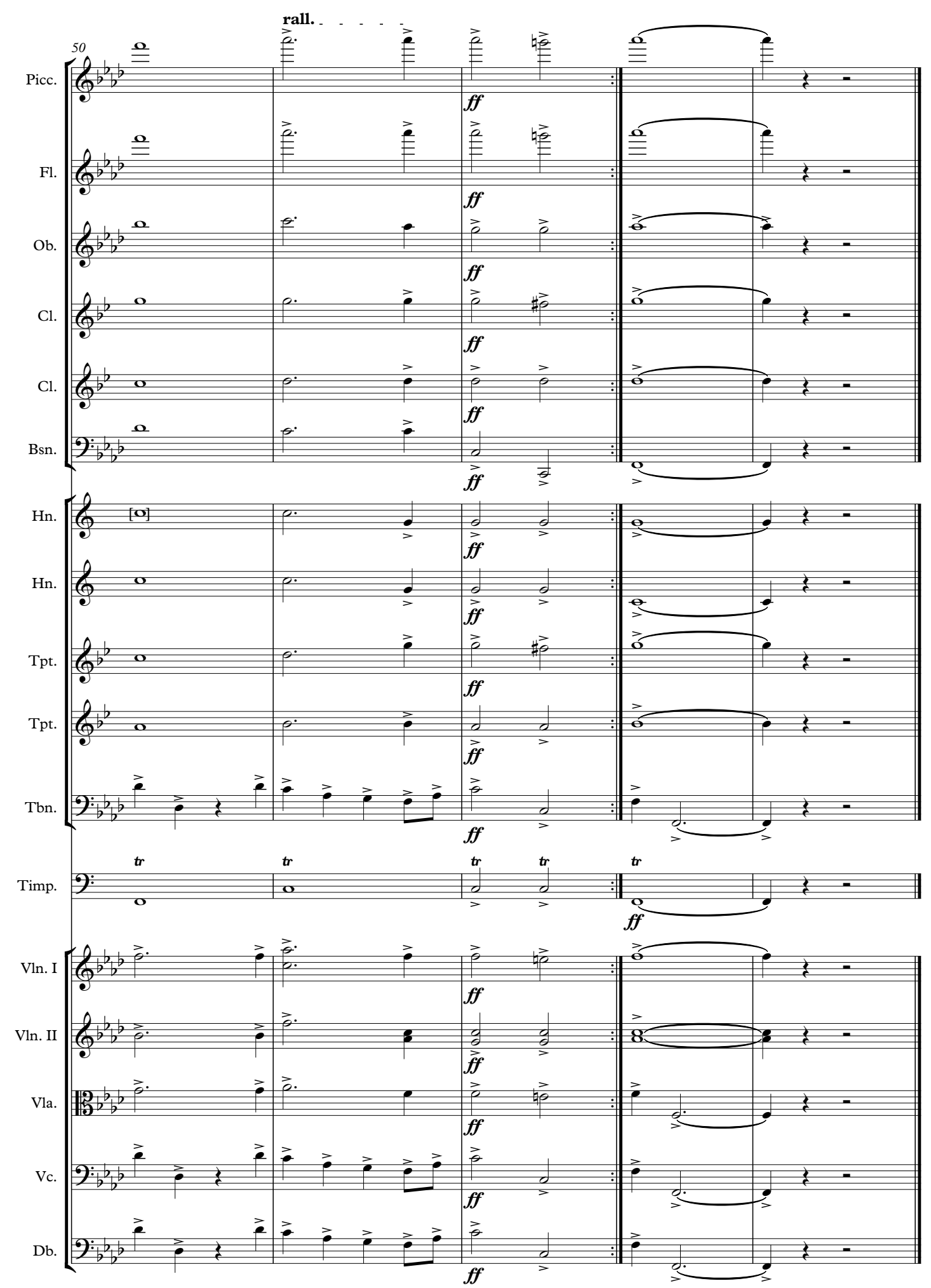
Reference List

Published

Amoamo, Jacqueline. 1993. 'A Creative Life: Ramai Hayward'. In Standing in the Sunshine - A History of New Zealand Women Since they Won the Vote, principal author Sandra Coney, 234-235. Auckland: Viking; Penguin Books.

Andersen, Johannes C. 1923. 'New Zealand and Other Bird-Song: Further Notes'. Transactions and Proceedings of the Royal Society of New Zealand 18681961 54:763-778.

. 1978. Maori Music with its Polynesian Background. Memoirs of the Polynesian Society, vol.10. New York: AMS Press. First printed 1934 by New Plymouth: Thomas Avery \& Sons.

Anderson, Benedict. 2006. Imagined Communities: Reflections on the Origin and Spread of Nationalism, revised edition. London; New York: Verso. First published 1983 London: Verso.

Annabell, Angela. 1975. 'New Zealand's Cultural and Economic Development Reflected in Song'. PhD diss., Auckland University.

Babington, Bruce. 2011. 'Epos Indigenized: The New Zealand Wars Film from Rudall Hayward to Vincent Ward'. In The Epic Film in World Culture, edited by Robert Burgoyne, 235-260. New York: Routledge.

Ballantyne, Tony. 2012. Webs of Empire: Locating New Zealand's Colonial Past. Wellington: Bridget Williams Books.

Ballantyne, Tony, and Antoinette Burton. 2009. 'The Politics of Intimacy in an Age of Empire'. In Moving Subjects: Gender, Mobility, and Intimacy in an Age of Global Empire, edited by Tony Ballantyne and Antoinette Burton, 1-28. Urbana; Chicago: University of Illinois Press.

'Band of the Grenadier Guards - History'. 2014. http://www.army.mod.uk/music /24530.aspx Accessed 7 May, 2014.

Barwell, Graham. 2005. 'Percy Grainger and the Early Collecting of Polynesian Music'. Journal of New Zealand Studies 2-3:1-17.

Belich, James. 1996. Making Peoples: A History of the New Zealanders from Polynesian Settlement to the End of the Nineteenth Century. Auckland: Allen Lane; Penguin.

2001. Paradise Reforged: A History of the New Zealanders from the 1880s to the Year 2000. Auckland: Allan Lane; Penguin.

Benshoff, Harry M., and Sean Griffin. 2009. America on Film: Representing Race, Class, Gender, and Sexuality at the Movies. Chichester, UK; Malden, MA: Wiley-Blackwell. 
Berger, Stefan. 2011. 'Narrating the Nation: Historiography and Other Genres'. In Narrating the Nation: Representations in History, Media, and the Arts, paperback edition, edited by Stefan Berger, Linas Eriksonas, and Andrew Mycock 1-16. New York; Oxford: Berghahn Books.

Blackley, Roger. 1997. Goldie. Auckland: Auckland Art Gallery Toi o Tāmaki in association with D. Bateman Ltd.

Blythe, Martin. 1994. Naming the Other: Images of Maori in New Zealand Film and Television. New Jersey: Scarecrow Press.

Bourke, Chris. 2010. Blue Smoke: The Lost Dawn of New Zealand Popular Music. Auckland: Auckland University Press.

Butler, Judith. 1999. Gender Trouble: Feminism and the Subversion of Identity, $2^{\text {nd }}$ edition. New York: Routledge.

Byars, Jackie. 1991. All That Hollywood Allows: Re-Reading Gender in 1950s Melodrama. Chapel Hill: University of North Carolina.

Campbell, Russell. 1986. 'In Order That They May Become Civilized: Pakeha Ideology in Rewi's Last Stand, Broken Barrier and Utu'. Illusions 1:4-15.

Carkeek, Rikihana. 2003. Home Little Maori Home: A Memoir of the Maori Contingent, 1914-1916. Wellington: Tōtika Publications.

Colquhoun, David. 2013. 'Cowan, James'. Last modified June 7. Dictionary of New Zealand Biography. Te Ara - The Encyclopedia of New Zealand. http://www.TeAra.govt.nz/en/biographies/3c36/cowan-james Accessed 8 May, 2014.

Cooper, Annabel. 2013. “Our Old Friends and Recent Foes”: James Cowan, Rudall Hayward and Memories of Natural Affections in the New Zealand Wars'. The Journal of New Zealand Studies 14:152-170.

Covell, Roger David. 1993. 'European Musical Nationalism in a Colonial Context'. History of European Ideas 16/4-6: 691-695.

Cowan, James. 1907. New Zealand, or Aoteäroa (The Long Bright World): Its Wealth and Resources, Scenery, Travel-Routes, Spas, and Sport. Wellington: John MacKay, Government Printer.

1910. Official Record of the New Zealand International Exhibition of Arts and Industries, Held at Christchurch 1906-7. Wellington: John MacKay, Government Printer.

. 1939a. 'The Battle of Orakau Pa', part 1. The New Zealand School Journal 33/2: 46-50.

. 1939b. 'The Battle of Orakau Pa', part 2. The New Zealand School Journal 33/3: 92-96. 
1983. The New Zealand Wars: A History of the Maori Campaigns and the Pioneering Period, vol.s 1 and 2. Wellington: P.D. Hasselberg, Government Printer. First published 1922 and 1923 Wellington: W. A. G. Skinner and R.E. Owen, Government Printer.

. 2000. The Old Frontier: Te Awamutu, the Story of the Waipa Valley. Facsimile edition. Papakura: Southern Reprints. First published 1922 Te Awamutu: Waipa Post and Publishing Co. Ltd.

Crowley, John Stephen. 2001. 'A Grand Old Man of Australian Music'. M.A. thesis, Monash University.

Derby, Mark. 2012a. 'Cultural Go-Betweens'. Last modified July 13. Te Ara - The Encyclopedia of New Zealand. http://www.TeAra.govt.nz/en/cultural-gobetweens/page-1 Accessed 8 May, 2014.

. 2012b. 'Selling Maoriland: Māori at the Centre of Tourism Publicity'. In Selling the Dream: The Art of Early New Zealand Tourism, edited by Peter Alsop, Gary Stewart, and Dave Bamford, 48-55. Nelson: Craig Potton Publishing.

Diamond, Paul. 2007. Makereti: Taking Māori to the World. Auckland: Random House.

Dominion String Quartet. 2007. Alfred Hill: String Quartets Volume One (Nos. 1-3). 8.570491. Hong Kong: Naxos Rights International.

Edwards, Sam, and Stuart Murray. 2007. 'A Rough Island Story: the Film Life of Rudall Charles Hayward'. In New Zealand Filmmakers, edited by Ian Conrich and Stuart Murray, 35-53. Detroit: Wayne State University Press.

Evans, Jennifer. 1994. 'Making of Orakau Battle Film Was Major Event in District'. Footprints of History 12:20-23.

Ferreira, Riette (J.M.). 2012. 'New Zealand Film Music in Focus: Music By New Zealand Composers for Feature Films'. PhD diss., University of Auckland.

Fox, Alistair. 2011. 'Rudall Hayward and the Cinema of Maoriland: Genre-mixing and Counter-Discourses in Rewi's Last Stand (1925), The Te Kooti Trail (1927) and Rewi's Last Stand/The Last Stand (1940)'. In New Zealand Cinema: Interpreting the Past, edited by Alistair Fox, Barry Keith Grant, and Hilary Radner, 45-64. Bristol, UK; Chicago, Ill.: Intellect.

Gibbons, P.J. 2014. 'Stowell, Henry Matthew'. Last modified February 26. Dictionary of New Zealand Biography. Te Ara - The Encyclopedia of New Zealand. http://www.TeAra.govt.nz/en/biographies/3s38/stowell-henrymatthew Accessed 3 March 2014.

Gibbons, Peter. 2002. 'Cultural Colonisation and National Identity' New Zealand Journal of History 36/1:5-17.

Gilkison, Alistair. 2008. Archive of New Zealand Sheet Music: A Bibliography. Wellington: A Gilkison. 
Hall, Stuart. 2013. 'The Spectacle of the “Other"'. In Representation, $2^{\text {nd }}$ edition, edited by Stuart Hall, Jessica Evans and Sean Nixon, 215-287. London: Sage; The Open University.

Harding, Mike. 1992. When the Pakeha Sings of Home: A Source Guide to the Folk and Popular Songs of New Zealand. Wellington: Godwit.

Hato, Ana, and Deane Waretini. 1929. Home, Little Maori, Home. A-2805 (A-414). Sydney: Parlophone.

1995. Ana Hato rāua ko Deane Waretini: Legendary Recordings 1927-1949. CD SLC-242. Wellington: Kiwi Pacific Records; National Library of New Zealand.

Hayward, Rudall (writ., dir., photo.). 1990. Rewi's Last Stand. VHS and booklet. Auckland: Hayward Historical Film Trust. Originally released as The Last Stand (re-edited) 1949. Britain: Equity British Films.

Hayward, Rudall, and A.W. Reed. 1944. Rewi's Last Stand, paperback edition. Wellington: A.H. and A.W. Reed; Raupo Books. First published 1939 Wellington; Dunedin: A.H. and A.W. Reed.

He Toa Takitini. 197-. He Toa Takitini. SCL 84. Wellington: Kiwi Pacific.

Heke, Hone, and A.T. Ngata. 1908. Souvenir of Maori Congress, July 1908: Scenes from the Past with Maori Versions of Popular English Songs. Wellington: Whitcombe \& Tombs.

Hill, Alfred. c.1904. Waiata Poi. Dunedin: John McIndoe. 1911. Home, Little Maori, Home. Auckland: A. Eady \& Co. . 1918a. Home, Little Maori, Home. Auckland: Arthur Eady and Co. . 1918b. Home, Little Maori, Home. Auckland: Arthur Eady Ltd 'The Old Firm'.

. 1926. Songs of the Maori: Collected and Arranged by Alfred Hill. Dunedin: John McIndoe.

1939a. Home, Little Maori, Home. New Zealand: Charles Begg and Co. Ltd.

1951. Alfred Hill's Maori Album. Sydney: Southern Music Publishing Co.

. 2008. The Leipzig Diary: Alfred Hill, edited by Donald Maurice. Wollongong, NSW: Wirripang.

Horton, Murray. 1973. 'Of Flicker Drammers and Maori Oscars'. Rolling Stone 12 April 42-44.

Iwi Hit Discs: 5 June 2000. 2000. Various artists. Wellington: NZ on Air.

Jensen, Owen. 1952. 'Alfred Hill, Douglas Lilburn, Burl Ives and All'. Landfall 6:236-238. 
Johnson, Henry. 2010. 'Introduction'. In Many Voices: Music and National Identity in Aotearoa/New Zealand, edited by Henry Johnson, 1-18. Newcastle upon Tyne: Cambridge Scholars Publishing.

Kernot, Bernard. 1998. 'Maoriland Metaphors and the Model Pa'. In Farewell Colonialism: The New Zealand International Exhibition Christchurch 190607, edited by John Mansfield Thomson, 79-94. Palmerston North: Dunmore Press.

King, Michael. 2008. Maori: A Photographic and Social History, revised edition. North Shore: Raupo Books.

Lam, Yuen Ching. 2006a. 'An Analytical Study of Alfred Hill's String Quartet No.2 in G Minor'. MA thesis, University of Otago.

. 2006b. 'The Māori Influence on Alfred Hill's Second String Quartet'. Canzona 26/48:49-51.

Lawn, Meredith. 2002. 'Musings of an Archivist: Arranging and Describing the Music Manuscripts of Alfred Hill at the State Library of New South Wales'. Fontes artis musicae 49/4:296-303.

Laing, Heather. 2007. The Gendered Score: Music in 1940s Melodrama and the Woman's Film. Aldershot, Hampshire, England; Burlington, VT: Ashgate.

Lilburn, Douglas. 1980. 'Introductory'. In A Distant Music: The Life and Times of Alfred Hill 1870-1960, by John Mansfield Thomson, n.p. Auckland; Melbourne: Oxford University Press.

. 2011. A Search for Tradition; A Search for Language. Wellington: Lilburn Residence Trust in association with Victoria University.

MacGibbon, John. 2007. Piano in the Parlour: When the Piano was New Zealand's Home Entertainment Centre. Wellington: Ngaio Press.

McCredie, Andrew. 1968. 'Alfred Hill (1870-1960): Some Backgrounds and Perspectives for an Historical Edition'. Miscellanea Musicologica 3:181-257.

McKinlay, Ernest. c.1925. Home, Little Maori, Home. 3527 (A2291). London: Columbia.

. c.1927. Home, Little Maori, Home. 01551 (T 757). Sydney: Columbia.

c.1928. Song of the Locust. 01061 (T 585). Sydney: Columbia.

. 1936. Maori Songs: Including 'Haere Ra' Collected and Sung by Ernest McKinlay. Sydney: W.H. Paling \& Co.

. 1939. Ways and By-Ways of a Singing Kiwi: With the N.Z. Divisional Entertainers in France. Dunedin: David M. Lister (printer).

McLean, Mervyn. 1996. Maori Music. Auckland: Auckland University Press. 
McLean, Mervyn, and Jeny Curnow. 1992. Catalogue of Museum of New Zealand Cylinder Recordings of Traditional Songs 1919-c1935. Auckland: Archive of Maori and Pacific Music, Anthropology Department, University of Auckland.

McLean, Mervyn, and Margaret Orbell. 2004. Traditional Songs of the Maori, $3^{\text {rd }}$ edition. Auckland: Auckland University Press.

McNiven, Ian J. and Lynette Russell. 2005. Appropriated Pasts: Indigenous Peoples and the Colonial Culture of Archeology. Lanham, MD: Altamira Press.

Maconie, Robin. 2006. 'Finding Alfred: The Search for a Lost Heritage', Canzona 26/48:32-45.

Maniopoto Voices, The. 1966. Maoritanga. RPLS-3458. Auckland: RCA Zodiac.

Martin, Helen, and Sam Edwards. 1997. New Zealand Film, 1912-1996. Auckland: Oxford University Press.

Marvelly, Elizabeth. 2008. Elizabeth Marvelly. Germany: EMI

Maurice, Donald. 2004. 'Alfred Hill (Arapeta Hira): The German, Australian, Kiwi Composer and Violist'. ANZVS 17:18-22. . 2006. 'Alfred Hill: The New Zealand Dvořák'. Canzona 26/48:46-48.

Middleton, Richard, and Peter Manuel. 2001. 'Popular Music, The West: Form'. In New Grove Dictionary of Music and Musicians, Vol. 20, $2^{\text {nd }}$ edition, edited by Stanley Sadie, 142-144. New York: Grove.

Mirams, Gordon. 1945. Speaking Candidly: Films and People in New Zealand. Hamilton: Paul's Book Arcade.

Mita, Merata. 1992. 'The Soul and the Image'. In Film in Aotearoa New Zealand, edited by Jonathan Dennis and Jan Bieringa, 36-54. Wellington: Victoria University Press with the assistance of the Film Programme of the Queen Elizabeth II Arts Council of New Zealand.

National Maori Choir. 2000. Songs of Inspiration: Waiata Taonga ma te Hinengaro. Rotorua: South Pacific Recordings.

Neill, Karen. 2005. 'Getting Radio-Friendly: The Rise of New Zealand Music on Commercial Radio'. In The Great New Zealand Radio Experiment, edited by Karen Neill and Morris William Shanahan, 153-174. Southbank, Victoria: Thomson; Dunmore Press.

Ngata, Āpirana. 1914. Songs, Haka and Ruri for the use of the Maori Contingent. Wellington: Government Printer.

O'Connor, Mary Ellen. 1979. 'Film and Myth: A Study of the Feature Films of Rudall Hayward'. M.A. research essay, University of Auckland.

Orsman, H.W. (ed.). 1997. The Dictionary of New Zealand English: A Dictionary of New Zealandisms on Historical Principles. Auckland: Oxford University Press. 
Pearson, David. 2001. The Politics of Ethnicity in Settler Societies: States of Unease. New York: Palgrave.

Perkins, Reid. 1996. 'Imag(in)ing Our Past'. Illusions 25:4-10.

Petersen, Anna K.C. 2000. 'The European Use of Maori Art in New Zealand Homes c.1890-1914'. In At Home in New Zealand: History, Houses, People, edited by Barbara Brookes, 57-72. Wellington: Bridget Williams Books.

Phillips, J.O.C. 1983. 'Musings in Maoriland - or Was There a Bulletin School in New Zealand?' Historical Studies 20/81:520-535.

Pisani, Michael V. 2005. Imagining Native America in Music. New Haven; London: Yale University Press.

Pivac, Diane. 2011.'The Rise of Fiction Between the Wars'. In New Zealand Film: An Illustrated History in Association with the Film Archive, edited by Diane Pivac with Frank Stark and Lawrence McDonald, 53-78. Wellington: Te Papa Press.

Plimmer, Harcus. 1953. 'He Captured Maori Music for the World: Salute to Our Prince of Music Makers, Alfred Hill'. New Zealand Country Magazine 3:15$16,24$.

Ratete, Tiawhi, and the Rotorua Maori Choir. 1930. Home, Little Maori, Home. D0-67 (T-924). Sydney: Columbia.

'Rewi's Last Stand'. 1954. Screen Parade September: 45.

'Rewi's Last Stand'. 1990. Te Iwi o Aotearoa 30:19.

Robinson, Sheila. 2014. 'Williams, Phyllis Constance'. Last modified 8 April. Dictionary of New Zealand Biography. Te Ara - The Encyclopedia of New Zealand. http://www.TeAra.govt.nz/en/biographies/5w34/williamsphyllis-constance Accessed 23 June, 2014.

Said, Edward W. 1995. Orientalism. London; New York: Penguin. First published 1978 Routledge \& Kegan Paul.

Schuster, Jim. 2012. Nga Taonga Whitiahua: Treasures from the Film Archive: Te Arawa and the History of Tourism in Rotorua, Lawrence Wharerau (int.). Screened 4 August. Māori Television in association with Ngā Kaitiaki O Ngā Taonga Whitiāhua The New Zealand Film Archive.

Shepard, Deborah. 2005. 'Shadow Play: The Film-Making Partnership of Rudall and Ramai Hayward'. In Between the Lives - Partners in Art, edited by Deborah Shepard, 113-135. Auckland: Auckland University Press.

Shieff, Sarah. 1994. 'Magpies: Negotiations of Centre and Periphery in Settings of New Zealand Poems by New Zealand Composers'. PhD diss., University of Auckland. 
Shingler, Martin. 2012. Star Studies: A Critical Guide. London: British Film Institute and Palgrave Macmillan.

Sklar, Robert. 1971.'Rudall Hayward, New Zealand Film-maker'. Landfall 98 25/2:147-154.

Stafford, Jane, and Mark Williams. 2006. Maoriland: New Zealand Literature 1872-1914. Wellington: Victoria University Press.

Steven, Geoff (dir.). 1985. Adventures in Maoriland: The Making of Hei Tiki. New Zealand: Phase Three Film Productions.

Stiles, Roy Allan. 2007. 'A Survey of the Music of Alfred Hill: Including a Thematic Catalogue'. PhD diss., Macquarie University.

Stiles Music Publications. 2008. 'Alfred Hill's Music'. http://www.stilesmusic publications.com/Alfred\%20Hill/Alfred\%20Hill\%20-\%20about $\% 20$ the $\%$ 20composer.htm Accessed 7 June, 2014.

Taruskin, Richard. 2001. 'Nationalism'. In The New Grove Dictionary of Music and Musicians, Vol.17, $2^{\text {nd }}$ edition, edited by Stanley Sadie, 689-706. New York: Grove.

Te Kanawa, Kiri. 1999. Maori Songs. CD. EMI LC6646. New York: EMI Classics.

Te Nahu, Elena. 2003. Elena. JAY382. Wellington: Elena; Jayrem Records.

Te Wiata, Inia. 1962. Maori Songs. 7EGO 70021. Sydney: His Master's Voice.

Thomas, Allan. 1981. 'Pacific Awareness in New Zealand Composition'. Canzona 3/10:27-34.

. 1998. 'The Savage Clubs: a Spirit of "Bohemian Comradeship"' Turnbull Library Record 31:43-62.

2011. 'Maori and Pakeha'. In Just Like Us: Aspects of New Zealand Music, edited by Robert Hoskins, Dugal McKinnon, Norman Meehan, and Allan Thomas, 9-20. Wellington: Steele Roberts Aotearoa.

Thomson, John Mansfield. 1980. A Distant Music: The Life and Times of Alfred Hill, 1870-1960. Auckland: Oxford University Press.

1991. The Oxford History of New Zealand Music. Oxford: Oxford University Press.

Walker, Paul. 2001. 'Fugue'. In The New Grove Dictionary of Music and Musicians, Vol.9, $2^{\text {nd }}$ edition, edited by Stanley Sadie, 318-332. New York: Grove.

Wanhalla, Angela. 2011. "The Meaning of "Colour": Photography and Portraiture, 1889-1904'. In Early New Zealand Photography: Images and Essays, edited by Angela Wanhalla and Erika Wolf, 116-121. Dunedin: Otago University Press. 
2013. Matters of the Heart: A History of Interracial Marriage in New Zealand. Auckland: Auckland University Press.

Wharerau, Lawrence. 1989. 'Ramai Hayward'. Koha. Television New Zealand. http://www.nzonscreen.com/title/koha-ramai-hayward-1989 Accessed 1 August, 2013.

Williams, Phyllis. 1998. 'He Oriori', arranged by Alfred Hill. On Alex Lindsay String Orchestra: 50 th Anniversary Commemorative Issue. CD SLDS-107. Wellington: Kiwi Pacific Records International. Originally recorded c. 1960.

Wolfe, Richard J. 1992. 'Melodies in Maoriland: Local Imagery in Early New Zealand Sheet Music'. Music in New Zealand 16:42-44.

\section{Unpublished}

Amohanga, Rehe. 1938. Letter to W.E. (Hon.) Parry. 8 February. IA1 W2578 113. C 483 287. ANZ.

Coubray, Edwin. 1980. Interviewed by Graham Shirley \& Chris Long. 28 May. Coubray, Edwin (Ted) Papers CD1009 MA1683. NZFA.

Cowan, James, 1870-1943. MS-Papers-11310-120. ATL.

Everton, E. H., 1860-1960. MS-Papers-57723. ATL.

Frontier Films Ltd. c.1940. 'Bulletin from the New Zealand Film Front'. Rewi's Last Stand press sheet. ARC3003/8/10. TAM.

‘Grand Maori Pageant'. 1919. Eph-A-Maori-Concerts-1900/1929. ATL.

Grefstad, Jan. n.d. 'The Picture Theatres of Auckland'. D1002.070.04. NZFA.

Hayward Collection. D5146. NZFA.

Hayward, Ramai. 1985. Letter to Russell Campbell. 5 November. Private collection. . 1986. 'Ramai Hayward Talks to Haare Williams'. ID47891. NZSA.

. 1996. 'Ramai Hayward Interviewed on Top o' the Morning with Brian Edwards'. ID37017. NZSA.

Hayward, Rudall. 1925. Rewi's Last Stand. F2290. NZFA.

. 1940. 'Twenty Years Behind a Movie Camera'. D5146.004.03. HC. NZFA. 1949. Rewi's Last Stand/The Last Stand. Equity British Films. F5690. NZFA. 1960. 'Alfred Hill by Rudall Hayward'. ID23841. NZSA. c.1961. Walter Harris (int.). AAOJ W5077 7811. Box 23. ANZ. 
c.1971. Press sheet. AAOJ W5077 7811. Box 23. ANZ.

Hill, Alfred. 1918c. Home, Little Maori, Home (annotated). MUSIC 780.1193 HIL HOME. ATL.

. 1939b. Home, Little Maori, Home (annotated). Music Box HILL Hom. ATL

[1950s]. 'Alfred Hill: Portrait from Life'. T1934. NZSA.

. 1952a. 'Alfred Hill and A D Heenan on Maori Music'. Auckland: National Broadcasting Service. Parts 1-5 MSD16-0150; MSD16-0151; MSD16-0152. Brian Hope Salkeld, 1926-1995, Papers and Sound Recordings MS-Group0281. ATL.

. 1952b. 'Alfred Hill Reminisces with John Gordon'. Auckland: National Broadcasting Service. Parts 1-3 MSD16-0153; MSD16-0154. Brian Hope Salkeld, 1926-1995, Papers and Sound Recordings. MS-Group-0281. ATL.

1958. 'Alfred Hill Interviewed by John Thomson'. T1935-T1937. NZSA.

Hill Family: Papers, Music and Pictorial Material of Alfred Hill and Mirrie Hill, 1854-1984. MLMSS6357. ML.

Hilliard, Chris. 2014. 'Stories of an Era Not Yet So Very Remote'. Paper presented at the symposium Cultural Go-Between, Colonial Man: New Perspectives on James Cowan, National Library, Wellington, 21 February.

Hongi, Hare (Henry Stowell). 1919. 'Haka'. 29 September. 75/007.01. AMPM.

'Maori Entertainment'. 1910. Eph-A-MAORI-CONCERT-1910-0. ATL.

'Maori Entertainment'. 1941. D5146/D6019. HC. NZFA.

Markey, Alexander. c.1935. Hei Tiki Press Book. George E. Turner Collection. Margaret Herrick Library. Academy of Motion Picture Arts and Sciences. 1935. Hei Tiki. USA: First Division. F5019. NZFA.

Meredith, Paul. 2014. 'Tēnā Koe, Hemi Kawana'. Paper presented at the symposium Cultural Go-Between, Colonial Man: New Perspectives on James Cowan, National Library, Wellington, 21 February.

Parry, W.E. (Hon.). 1938. Letter to Rehe Amohanga. 9 March. IA1 W2578 113. C 483 287. ANZ.

Partington, William Henry Thomas. c.1910. 'Makereti Papakura'. Auckland Star Negatives. 1/1-003055-G. PA-Group-00610. ATL.

Stowell, Henry Matthew, 1859-1944, Papers. MS-Papers-0062. ATL.

Te Awamutu Courier [clippings]. Rewi's Last Stand - Assorted. ACR3630. TAM.

Te Miha, Ramai. c.1940. PH299. TAM. . c.1940. PH302. TAM. 
Te Ua, Henare. 1996. Whenua. 17 November. ID52350. NZSA.

Thomson, John Mansfield 1929-1999: Photographs of Alfred Hill/ Photographs relating to Alfred Hill. ATL.

Wellington Savage Club: Records. 85-027-1/1; MSY-4399. MS-Group-0557. ATL.

Williams, Phyllis. n.d. 'Maori Song Forms'. Fowler, Leo, fl.1938-1972. MS-Group2244. ATL. 